\title{
Recent Progress of Metal Nanoparticle Catalysts for C-C Bond Forming Reactions
}

\author{
Atsushi Ohtaka (D) \\ Department of Applied Chemistry, Faculty of Engineering, Osaka Institute of Technology, 5-16-1 Ohmiya, Asahi, \\ Osaka 535-8585, Japan; atsushi.otaka@oit.ac.jp; Tel.: +81-6-6954-4729 \\ Abstract: Over the past few decades, the use of transition metal nanoparticles (NPs) in catalysis has \\ attracted much attention and their use in $\mathrm{C}-\mathrm{C}$ bond forming reactions constitutes one of their most \\ important applications. A huge variety of metal NPs, which have showed high catalytic activity \\ for $\mathrm{C}-\mathrm{C}$ bond forming reactions, have been developed up to now. Many kinds of stabilizers, such \\ as inorganic materials, magnetically recoverable materials, porous materials, organic-inorganic \\ composites, carbon materials, polymers, and surfactants have been utilized to develop metal NPs \\ catalysts. This review classified and outlined the categories of metal NPs by the type of support.
}

check for updates

Citation: Ohtaka, A. Recent Progress of Metal Nanoparticle Catalysts for $\mathrm{C}-\mathrm{C}$ Bond Forming Reactions. Catalysts 2021, 11, 1266. https:// doi.org/10.3390/catal11111266

Academic Editor: Moris S. Eisen

Received: 6 October 2021

Accepted: 18 October 2021

Published: 21 October 2021

Publisher's Note: MDPI stays neutral with regard to jurisdictional claims in published maps and institutional affiliations.

Copyright: (C) 2021 by the author. Licensee MDPI, Basel, Switzerland. This article is an open access article distributed under the terms and conditions of the Creative Commons Attribution (CC BY) license (https:// creativecommons.org/licenses/by/ $4.0 /)$.
Keywords: metal nanoparticles; support; $\mathrm{C}-\mathrm{C}$ bond forming reactions

\section{Introduction}

The synthesis of new functional molecules and the development of new reactions are important fields at the core of synthetic organic chemistry. Among them, $\mathrm{C}-\mathrm{C}$ bond formation is one of the most important reactions. Until now, numerous kinds of $\mathrm{C}-\mathrm{C}$ bond forming reactions, including regioselective reactions, stereoselective reactions, and cross-coupling reactions such as Suzuki-Miyaura, Mizoroki-Heck, Stille, Hiyama, Ullmann, and Sonogashira coupling reactions, have been developed and applied to synthesize many kinds of functional molecules such as drugs, natural products, optical devices, and industrially important starting materials. Homogeneous transition metal catalysts act in a pivotal role to achieve the above reactions, a huge kind of catalysts and ligands have been developed. However, homogeneous catalysts have a number of drawbacks, in particular, the lack of reuse of the catalyst. This leads to a loss of expensive metals and ligands and to impurities in the products. Although numerous kinds of heterogeneous catalysts have been developed in order to address these problems, heterogeneous catalysts are inferior to homogeneous catalysts at some points, such as in reactivity.

On the other hand, transition metal nanoparticles (NPs), which can be readily obtained by several methods, such as chemical reductions and thermal decompositions, are of great interest due to their high reactivity derived from their extremely small size and their large surface to volume ratio. Metal NPs have received much attention for their use in many promising catalytic and biomedical applications because they exhibit unique magnetic and catalytic properties that are not shown in bulk materials. The pioneering catalytic application of metal NPs was reported by Rampino and Nord in 1941 [1]. Since the pioneering works on $\mathrm{C}-\mathrm{C}$ coupling reaction by metal NPs were reported by Reetz in 1996 [2,3], over the last few decades, the use of transition metal NPs in catalysis has expanded considerably and a huge variety of metal NP catalysts have been developed. Due to the enormous number of publications outlining metal NPs in recent years [4-30], this review will only focus on the metal NPs used as a catalyst for C $-\mathrm{C}$ bond forming reactions over the last five years. This review classified and outlined the categories of metal NPs by the type of support, such as inorganic materials, magnetically recoverable materials, porous materials, organic-inorganic composites, carbon materials, polymers and surfactants (Scheme 1). 


\section{Inorganic materials}

Magnetically recoverable materials

Porous materials

Organic-Inorganic composites

Carbon materials

Organic polymers and surfactants

Others
Metals, metal oxides, clays, etc.

$\mathrm{Fe}_{3} \mathrm{O}_{4}, \mathrm{MFe}_{2} \mathrm{O}_{4}$, materials functionalized on $\mathrm{Fe}_{3} \mathrm{O}_{4}$, etc.

Materials with porous structure such as zeolite and covalent organic frameworks, etc. MOFs, inorganic materials functionalized by organic molecules, etc.

Carbon, carbon nanotubes, graphene, graphene oxides, carbon nitrides, etc.

Polymers, dendrimers, plants extract, polysaccharides, surfactants, etc.

Organic molecules with low molecular weight such as solvents and phosphines, etc.

Scheme 1. Category of support.

\section{Several Supports for Metal Nanoparticles}

\subsection{Inorganic Materials}

One of the most fundamental supports for metal NPs is inorganic materials such as metal oxides, clay, and so on [31-33]. There have been developed many highly active inorganic materials and supported metal NP catalysts, such as those which proceed the C-C bond forming reaction at room temperature [34-51]. Typical recent examples include the following:

Trudell et al. reported a reliable method for the encapsulation of Pd NPs in halloysite, and the resultant Pd@halloysite catalyzed the Suzuki-Miyaura coupling reaction of aryl bromides at room temperature [52]. Verberckmoes et al. found that uncalcined, co-precipitated hydrotalcite-supported Pd NP catalysts are preferred above the calcined, impregnated ones when catalyzing basic promoted organic reactions. The reason for this is that the lack of calcination resulting in an ordered and porous hexagonal hydrotalcite structure causes a high accessibility of the active centers in combination with the high support basicity [53]. Pd NPs stabilized on magnesium oxide-carbon quantum dots catalyzed the Suzuki-Miyaura coupling reaction of aryl bromides and chlorides at room temperature. In addition, Pd loading and leaching in catalysts can be estimated by using fluorescence emission because a good relationship was observed between fluorescence intensity and the loading of Pd [54].

Miura and Shishido et al. developed one-pot synthesis of cyclohexene derivatives from the reductive cycloisomerization of diynes and subsequent [4+2] cycloaddition with dienophiles, based on the hypothesis that Pd species functioned as a redox site to form a palladacycle via the oxidative addition of two alkyne moieties (Scheme 2) [55]. They also found that the $[2+2+2]$ cycloaddition of alkynes proceeded smoothly by PdAu alloy NPs while monometallic Pd and Au NPs were ineffective $[56,57]$. In the hydroalkoxycarbonylation of olefins using $\mathrm{Ru}$ NPs on $\mathrm{CeO}_{2}$, controlling the regioselectivities of linear esters and branched esters has been found to be related to the $\mathrm{Ru}$ size [58,59]. The Ru/Ceria catalyzed quinazolinones synthesis was also achieved by the same group (Scheme 3) [60].

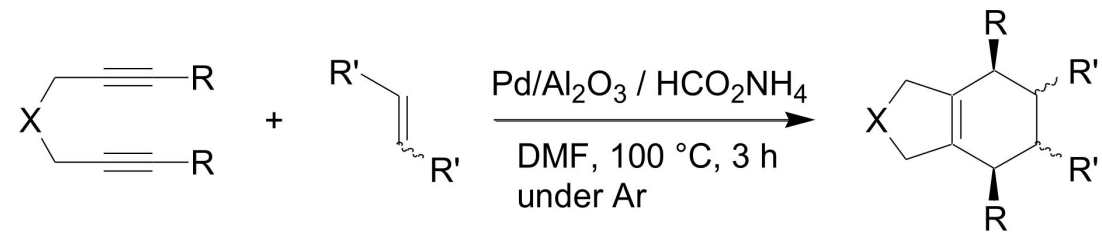

15 examples

$17-78 \%$ yield

Scheme 2. One-pot synthesis of cyclohexene derivatives by Miura and Shishido et al. Reproduced from [55], Wiley-VCH: 2020. 


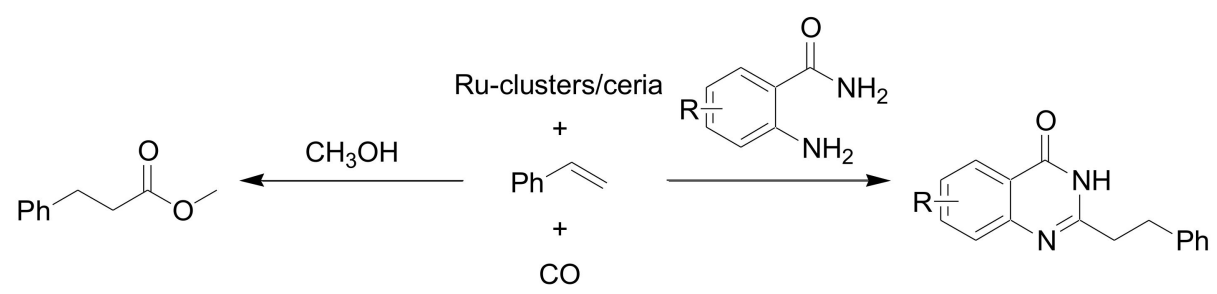

Scheme 3. Three-component coupling reactions catalyzed by Ru-clusters/ceria. Reproduced from [58], Elsemier: 2020 and [60], Wiley-VCH: 2018.

Metal NPs have been also applied to polymerization reactions. Cu NPs supported on $\mathrm{SiO}_{2}$ catalyzed the controlled living radical polymerization to afford poly (n-butyl acrylate) and poly (n-butyl acrylate-block-styrene) [61]. Pd NPs coated on the surface of the fabricated titanate nanotubes was utilized for electrochemical polymerization of $o$-phenylenediamine in acid medium [62].

Huge efforts have been devoted to develop the metal NPs as a photocatalyst for $\mathrm{C}-\mathrm{C}$ bond forming reactions. Hosseini-Sarvari et al. reported the synthesis of nano $\mathrm{Pd} / \mathrm{TiO}_{2}$ with band gap $>3 \mathrm{eV}$ through a photodeposition method under sunlight, and their activity for Suzuki-Miyaura coupling reaction under visible light irradiation [63]. They also reported photocatalytic activity of nano Pd/ZnO for Suzuki-Miyaura, Hiyama, and Buchwald-Hartwig reactions under visible light irradiation at ambient temperature [64]. The study of Lanterna and Scaiano et al. indicated that the direct excitation of Pd NPs can catalyze Sonogashira coupling reaction [65]. The same research group also found that the Ullmann coupling reaction of aryl iodides proceeded smoothly under both UV and visible light irradiation in the presence of $\mathrm{Pd} @ \mathrm{TiO}_{2}$ whereas a similar dose of visible light did not initiate the reaction [66]. The photocatalytic activity of Pd NPs supported on $\mathrm{SiC}$ in Sonogashira coupling reaction under visible light irradiation has been also reported. The rate of the photocatalytic reaction can be controlled by the light intensity and irradiation wavelength respectively [67]. Yoshida et al. found a blended catalyst of $\mathrm{TiO}_{2}$ and $\mathrm{Pd}-\mathrm{Au} / \mathrm{Al}_{2} \mathrm{O}_{3}$ showed high catalytic activity for photocatalytic Ullmann coupling reaction (Scheme 4). The photogenerated electrons on the $\mathrm{TiO}_{2}$ photocatalyst reduced the aryl halide to generate the corresponding radical species, while the $\mathrm{Pd}-\mathrm{Au}$ bimetallic nanoparticles activated another aryl halide and facilitated its reaction with the photogenerated aryl radical to yield biaryls. To improve of both the photocatalyst and the metal NPs independently is an attractive and promising approach to improve the entire catalytic performance [68]. The coupling reaction of pyridine with benzene and THF with alkane, alkene, and arene using Pt NPs or Pd-Au NPs loaded $\mathrm{TiO}_{2}$ photocatalyst have been also reported by the same research group [69-72].

\begin{tabular}{|c|c|c|}
\hline & $\begin{array}{c}\mathrm{Pd}(2.0) \mathrm{Au}(1.0) / \mathrm{Al}_{2} \mathrm{O}_{3} \\
+ \\
\mathrm{TiO}_{2}\end{array}$ & \\
\hline & $\mathrm{MeOH}, \mathrm{NaOH}, 25^{\circ} \mathrm{C}$ & $\mathrm{Ar}-\mathrm{Ar}$ \\
\hline $\mathrm{X}=\mathrm{I}, \mathrm{Br}, \mathrm{Cl}$ & $\begin{array}{l}\mathrm{h} v, \lambda>350 \mathrm{~nm}, \\
30-60 \mathrm{~min}, \text { under } \mathrm{Ar}\end{array}$ & $\begin{array}{c}8 \text { examples } \\
15-84 \% \text { yield }\end{array}$ \\
\hline
\end{tabular}

Scheme 4. Photocatalytic Ullmann coupling with the blended catalyst consisting of $\mathrm{TiO}_{2}$ and Pd$\mathrm{Au} / \mathrm{Al}_{2} \mathrm{O}_{3}$. Reproduced from [68], RSC: 2018.

Surface structure engineering has afforded many breakthroughs in enhancing the photocatalytic activity of titania. Among them, readily accessible urchin-like structures with properties of an interconnected porous framework and a high specific surface area and can increase the efficiency of light harvesting as well as facilitate the accessibility of reactants to the active sites [73]. $\mathrm{InP} / \mathrm{ZnS}$ quantum dots were used as a sole photocatalyst to catalyze the $\mathrm{C}-\mathrm{C}$ coupling reaction between 1-phenyl pyrrolidine and phenyl-trans-styryl sulfone without the aid of any cocatalyst or sacrificial oxidant or reductant [74]. The density 
functional theoretical (DFT) calculations of the adsorption energies of reaction intermediates leads to a design of the photocatalyst. Su et al. found the $\mathrm{Cu} \mathrm{NP}$-modified $\mathrm{TiO}_{2}$ presented a high selectivity towards photocatalytic homocoupling of benzyl bromide into bibenzyl with a remarkable apparent quantum efficiency (AQE) of $15 \%$ by evaluation of the adsorption energies of benzyl radicals and bromine atoms on a series of selected metal surfaces (Scheme 5) [75]. $\mathrm{Cu}_{2} \mathrm{O}$ NPs supported on graphitic carbon nitride make a photoactive catalyst that has been developed for the preparation of ynone, aminoindolizines, and pyrrolo [1,2-a] quinoline. The electrons present in the conduction band under irradiation play an important role in enhancing the charge density of the $\mathrm{Cu}_{2} \mathrm{O}$ NPs, which strengthens the $\pi$-complex between $\mathrm{Cu}_{2} \mathrm{O}$ NPs and alkyne molecules, and acting as scavengers for the terminal hydrogen of alkyne to form the copper acetylide complex (Scheme 6) [76]. The size effect of $\mathrm{Pt}$ on the photocatalytic nonoxidative methane conversion efficiency was systematically investigated over $\mathrm{x}-\mathrm{Pt} / \mathrm{Ga}_{2} \mathrm{O}_{3}$ with the particle size $(\mathrm{x})$ ranging from 1.5 to $2.7 \mathrm{~nm}$, where a volcano-shaped relation was observed [77].

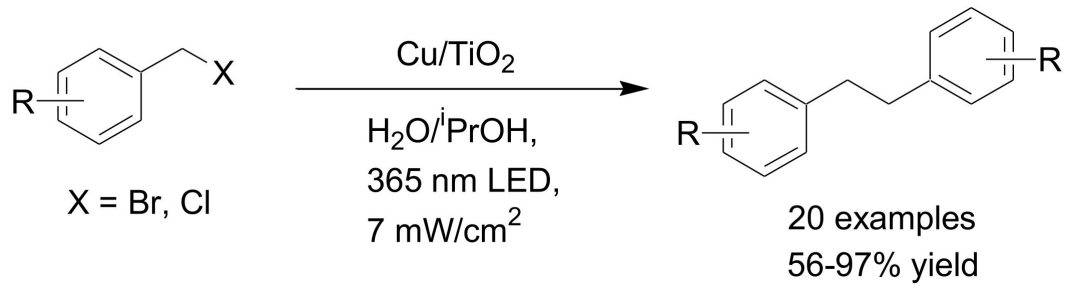

Scheme 5. Photocatalytic dehalogenative coupling of benzyl bromides using $\mathrm{Cu} / \mathrm{TiO}_{2}$ photocatalyst. Reproduced from [75], ACS: 2021.
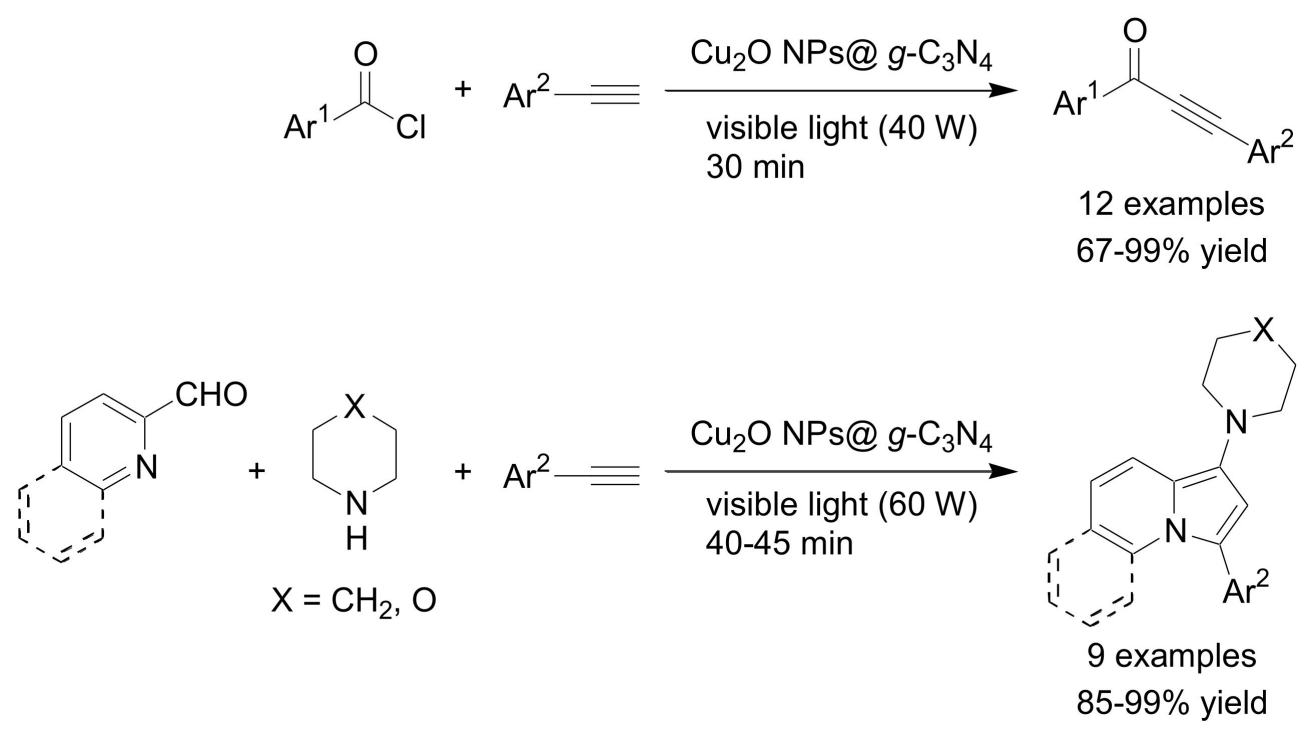

Scheme 6. $\mathrm{Cu}_{2} \mathrm{O} N P s / g-\mathrm{C}_{3} \mathrm{~N}_{4}$ catalyzed synthesis of ynones, aminoindolizines, and pyrrolo[1,2a]quinolones. Reproduced from [76], ACS: 2020.

The nature of the metal nanoparticle cocatalyst deposited on a $\mathrm{TiO}_{2}$ photocatalyst dictated the product selectivity for the cross-coupling. The reaction of toluene with acetone gave 1-(o-tolyl)propan-2-one in the presence of Pd NPs, while Pt NPs promoted the crosscoupling reaction between the methyl group of toluene and acetone to afford 4-phenylbutan2-one (Scheme 7) [78]. 


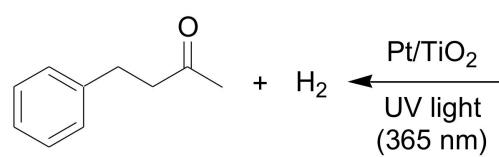

selectivity: $96 \%$

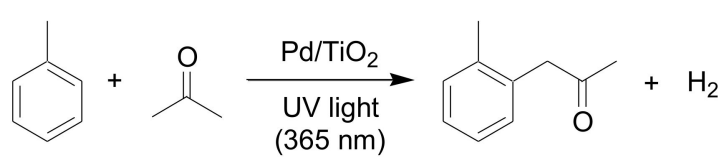

selectivity: $89 \%$ regioselectivity: $77 \%$

Scheme 7. Selective photoreaction using metal immobilized on $\mathrm{TiO}_{2}$. Reproduced from [78], Springer: 2020.

\subsection{Magnetically Recoverable Materials}

Metal NPs with a magnetic core can be easily separated from the reaction mixture by using an external magnet. Magnetic separation is an alternative to filtration or centrifugation as it prevents loss of catalyst and increases the reusability. This makes materials like $\mathrm{Fe}_{3} \mathrm{O}_{4}$ a promising support for nanocatalysts. Magnetic nanoparticles have received considerable attention in terms of biocompatibility, thermal stability against degradation, large surface area, and low cost. Therefore, it is suitable for designing magnetically retrievable metal NPs [79-86]. Lately, many excellent studies about magnetic composite nanocatalysts have been reported [87-118].

Nasseri et al. improved their bifuncitional catalytic system based on copper with an ionic tail reported in 2019, and developed a magnetically water dispersible $\mathrm{Cu}-\mathrm{Co}$ bimetallic catalyst for the efficient base/Pd-free C-C and C-N cross-coupling reactions [119,120]. Magnetite coated by amino acid functionalized chitosan in consideration of improving physicochemical properties such as solubility and mucoadhesiveness, was used as a support for Pd NPs. On using this catalyst, the Suzuki-Miyaura and Sonogashira coupling reactions were carried out efficiently at room temperature [121]. Based on this, a new catalytic system with an extremely low loading of expensive metal (ppm or ppb) has been developed. Eshghi et al. developed arginine-modified $\mathrm{Fe}_{3} \mathrm{O}_{4} @$ @arbon magnetic nanoparticles with highly dispersed $\mathrm{Cu}$ NPs and ppm levels of Pd [122]. To improve the catalytic activity, nitrogen-doped materials are used as a support [123,124]. According to this idea, Shen and Qiao et al. synthesized novel magnetically $\mathrm{Fe}_{3} \mathrm{O}_{4} @ \mathrm{Pd} \mathrm{NPs}$ by fixing Pd on the surface of nitrogen-doped magnetic nanocomposites (Scheme 8) [125]. Hajipour et al. synthesized magnetically separable nano-nickel catalysts, which catalyzed efficiently for fluoride-free Hiyama coupling reaction, through a "click" reaction of azidefunctionalized magnetic nanoparticles with 2-ethynylpyridine followed by immobilization of nickel nanoparticles [126]. Co NPs immobilized on magnetic chitosan has been used for the first time for the cyanation of aryl halides, and also promoted the Hiyama coupling reaction (Scheme 9) [127].

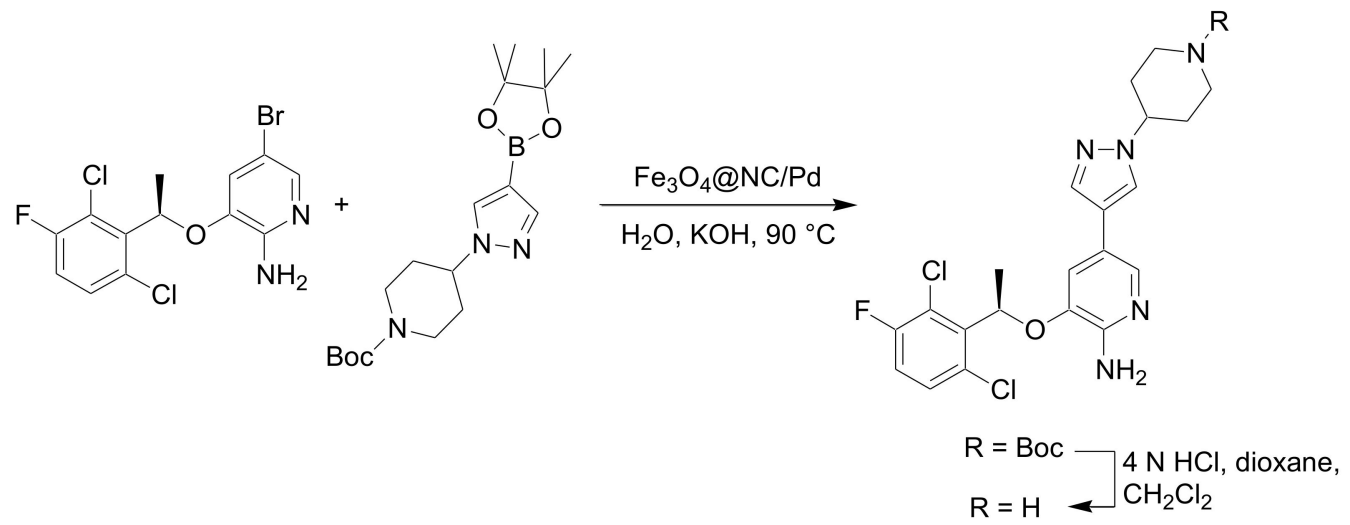

Scheme 8. Application of $\mathrm{Fe}_{3} \mathrm{O}_{4} @ \mathrm{NC} / \mathrm{Pd}$ in the synthesis of crizotinib. Reproduced from [125], MDPI: 2018. 


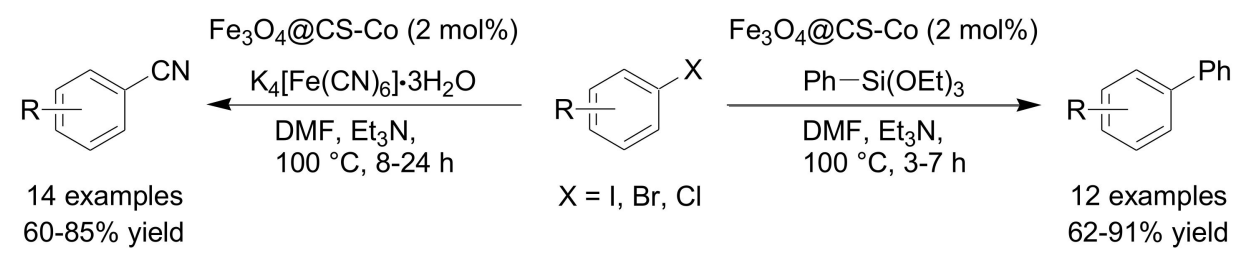

Scheme 9. Cyanations and Hiyama coupling reactions using Co NPs immobilized on magnetic chitosan. Reproduced from [127], ACS: 2020.

$\mathrm{A} \mathrm{Fe}_{3} \mathrm{O}_{4}$ /oleic acid/Pd NPs catalyst was used for the Sonogashira polymerization. The polymerization occurred by a step-growth mechanism and resulted in a molar mass of $3.8 \mathrm{~kg} / \mathrm{mol}$ [128]. The sequential Knoevenagel condensation/1,3-dipolar cycloaddition reactions proceeded using $\mathrm{Fe}_{3} \mathrm{O}_{4} @ \mathrm{SiO}_{2} @ \mathrm{Au}$ catalyst to give substituted spiroisoxazoines and oxadiazoles with good regio- and stereoselectivity under mild reaction conditions (Scheme 10) [129].

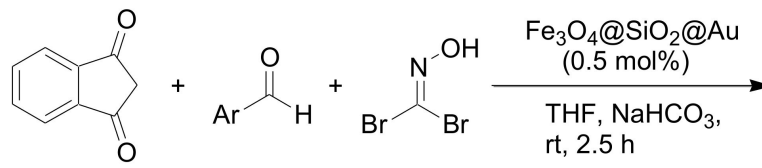<smiles>O=C1c2ccccc2C(=O)C12NOC(Br)=NC2Br</smiles>

5 examples $75-87 \%$ yield
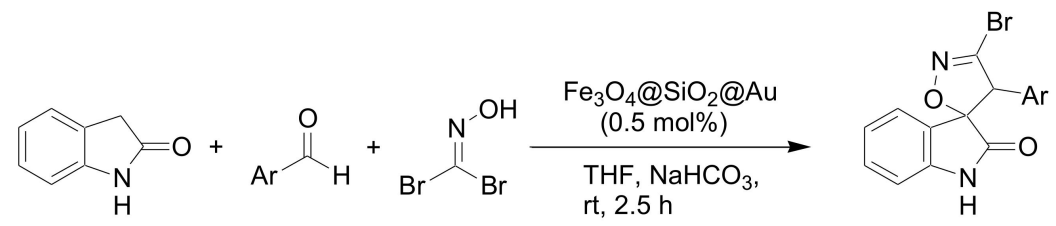

7 examples $78-87 \%$ yield

$$
\mathrm{X}=\mathrm{CONH}_{2}, \mathrm{CN}
$$

Scheme 10. Synthesis of spiroisoxazorines and oxadiazoles using $\mathrm{Fe}_{3} \mathrm{O}_{4} @ \mathrm{SiO}_{2} @ \mathrm{Au}$ catalyst. Reproduced from [129], Elsevier: 2020.

Bhalla et al. developed a supramolecular porous ensemble consisting of oligophenylene derivatives and $\mathrm{Au}-\mathrm{Fe}_{3} \mathrm{O}_{4}$. A series of catalysts efficiently catalyzed Kumada reaction, Heck reaction, and the synthesis of quinoline carboxylates (Scheme 11) [130-132]. Azadi and Kazemi et al. prepared the core-shell magnetic nano photocatalyst. The catalyst composed of a central magnetite core, an interlayer of silica, a shell of titania, and finally a Schiff base complex of Pd NPs. The Suzuki-Miyaura coupling reaction occurred under blue LED irradiation, while no product was obtained under a white and green LED irradiation (Scheme 12) [133].

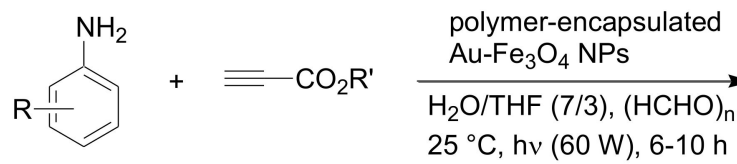

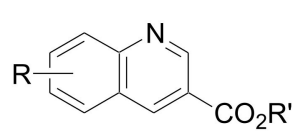

$$
\begin{aligned}
& 16 \text { examples } \\
& 40-85 \% \text { yield }
\end{aligned}
$$

Scheme 11. Photocatalytic synthesis of quinoline carboxylates through a $\mathrm{C}\left(\mathrm{sp}^{2}\right)$-H activation reaction. Reproduced from [132], ACS: 2017. 


$$
\begin{array}{lll}
\mathrm{Ar}^{1}-\mathrm{X}+\mathrm{Ar}^{2}-\mathrm{B}(\mathrm{OH})_{2} \underset{\mathrm{Fe}_{3} \mathrm{O}_{4} @ \mathrm{SiO}_{2} @ \mathrm{TiO}_{2} \text { Schiff base@Pd }}{\mathrm{PEG}, \mathrm{K}_{2} \mathrm{CO}_{3}, \mathrm{LED} 20 \mathrm{~W}} & \mathrm{Ar}^{1}-\mathrm{Ar}^{2} \\
\mathrm{X}=\mathrm{I}, \mathrm{Br} & & 20 \text { examples } \\
& 86-99 \% \text { yield }
\end{array}
$$

Scheme 12. Visible-light-driven photocatalytic Suzuki-Miyaura Coupling reaction. Reproduced from [133], Wiley-VCH: 2021.

\subsection{Porous Materials}

Several porous materials, such as zeolite, mesoporous silica, covalent organic frameworks (COFs), and microporous organic polymers (MOPs), have also been utilized as the support for metal NPs. These materials possess several highly desirable properties: pore topologies that possess long-range structural ordering, a uniform pore size, and high surface areas. Due to the typical advantages of the porous supports, the size control of the stabilized metal NPs and the selective reactions dependent on the pore size have been achieved [134-151].

$\mathrm{Li}$ and Chen et al. confirmed that the number of acid sites within the zeolite frameworks were directly proportional to the catalytic activity of Pd NPs in Suzuki-Miyaura coupling reaction [152]. Gu and Zhang et al. have developed a novel covalent organic framework (COFs)-templated strategy for the size-controlled synthesis of stable and highly dispersed ultrafine metal NPs. With the aid of the evenly distributed thioether groups in the ordered framework structure, ultrafine metal NPs with a narrow size distribution were successfully obtained [153]. Arisawa et al. developed a well-established metal-nanoparticle catalyst preparative protocol by simultaneous in situ metal NPs and nanospace organization (PSSO). Several sulfur-modified Au-supported metal (Pd, Ni, Ru, and Fe) catalysts were constructed by self-assembled metal NPs, which were encapsulated in a sulfated $p$-xylene polymer matrix, and showed high catalytic activities for several $\mathrm{C}-\mathrm{C}$ coupling reactions (Scheme 13) [154-158].

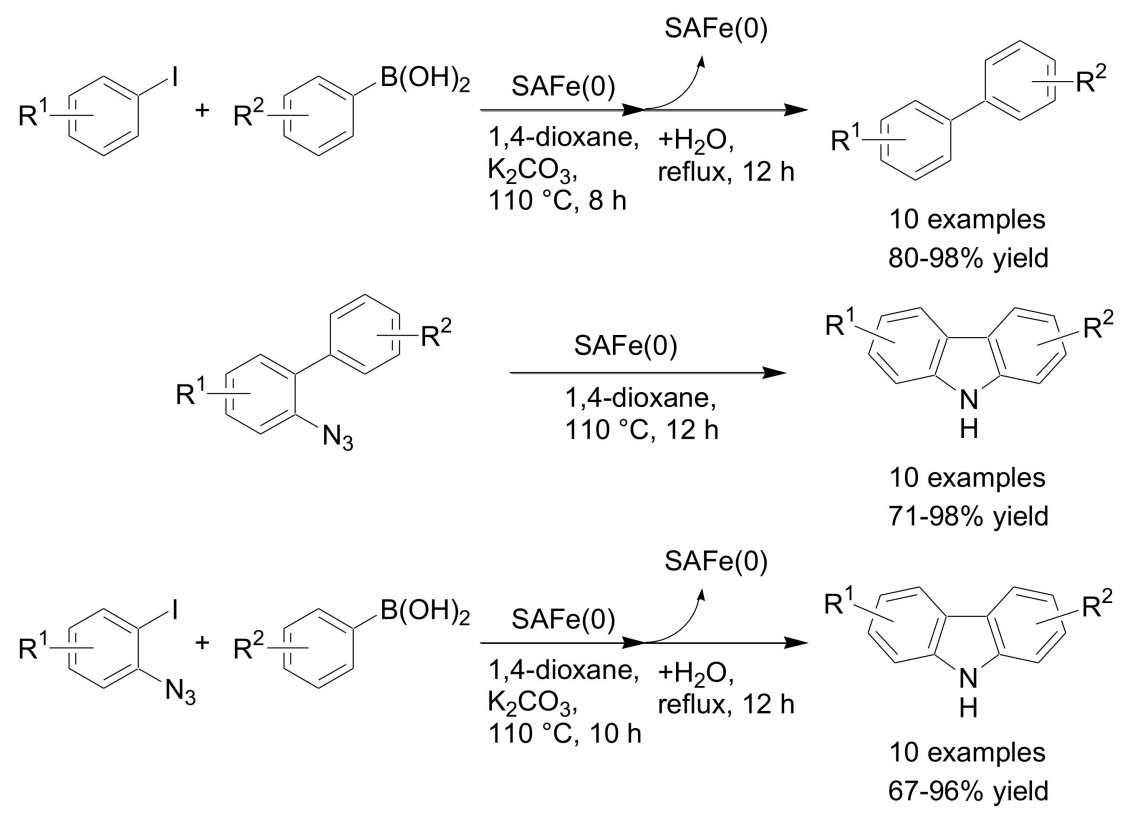

Scheme 13. One-pot synthesis of carbazole derivatives catalyzed by self-assembled multilayer $\mathrm{Fe}(0)$ NPs. Reproduced from [154], ACS: 2020.

El-Shall et al. found that ultra-small CuPd bimetallic nanoparticles deposited on a mesoporous-fumed silica support could be participated efficiently to the Suzuki-Miyaura coupling reaction of aryl bromides to give the corresponding coupling product within 30 min [159]. Bae, Byun, and Kim et al. prepared small and large Au NPs stabilized in mesoporous $\mathrm{TiO}_{2}$ and poly(N-isopropylacrylamide) particles, respectively. These Au NPs 
exhibited a notably high catalytic activity in the homocoupling of phenylboronic acid, and interestingly, there was no obvious correlation between the apparent $E_{a}$ values and the size of Au NPs [160]. Dewan et al. reported the first synthesis of a renewable, recyclable, environmental benign bio-nanocellulose-based honeycomb-like heterogeneous surface from waste pomegranate peel. Pd NPs loaded onto the bio-nanocellulose is the effective catalyst for $\mathrm{C}-\mathrm{C}$ coupling reaction to synthesize the potential bioactive biaryl/heterobiaryl and alkynyl/heteroalkynyl derivatives (Scheme 14) [161].

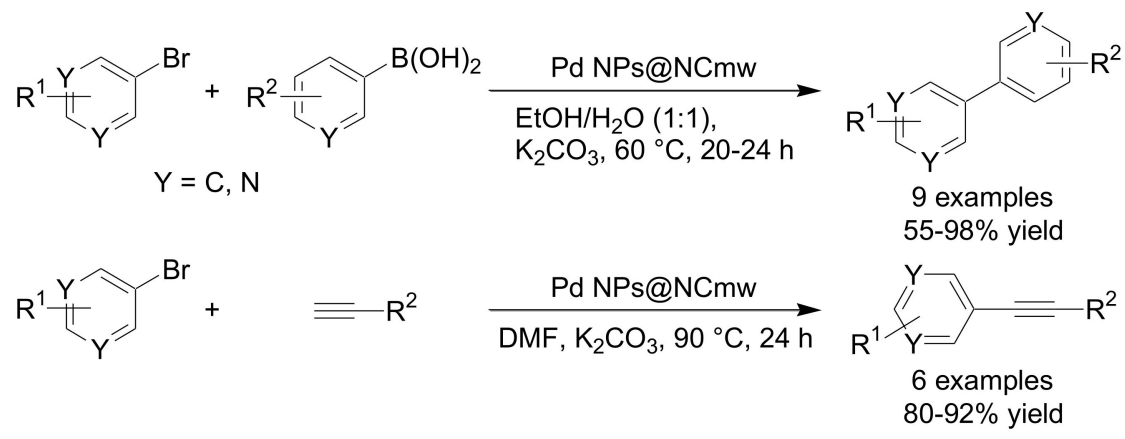

Scheme 14. Heteroaryl cross-coupling reactions catalyzed by Pd NPs@NCmw. Reproduced from [161], ACS: 2021.

Xie et al. reported a one-step strategy for the design of size-selective heterogeneous catalysts, which was composed of microporous polymer carriers and ultrafine Pd NPs. This research will expand the application scope of microporous organic polymers in sizeselective heterogeneous catalysis (Scheme 15) [162]. Product selectivity is attributable to the size selectivity of micropores. Pt NPs encapsulated in H-BEA zeolite (Pt@H-BEA) catalyzed a one-step conversion of biomass-derived cyclopentanone to $\mathrm{C} 10$ cyclic hydrocarbons, i.e., bicyclopentane and decalin. While cyclopentane was produced with a yield of $>70 \%$ on Pt@H-ZSM-5, which have the narrower pores (Scheme 16) [163]., Shi et al. achieved the selective synthesis of 3-methylindole from the reaction of aniline with glycerin using $\mathrm{Cu}$ NPs/SBA- 15 modified with $\mathrm{Al}_{2} \mathrm{O}_{3}, \mathrm{La}_{2} \mathrm{O}_{3}$, and $\mathrm{CoO}$. The characterizations revealed that the effect of $\mathrm{Al}_{2} \mathrm{O}_{3}, \mathrm{La}_{2} \mathrm{O}_{3}$, and $\mathrm{CoO}$ to enhance the polarity of the carrier, weaken the acidity, and to increase the number of weak acid centers, respectively (Scheme 17) [164].

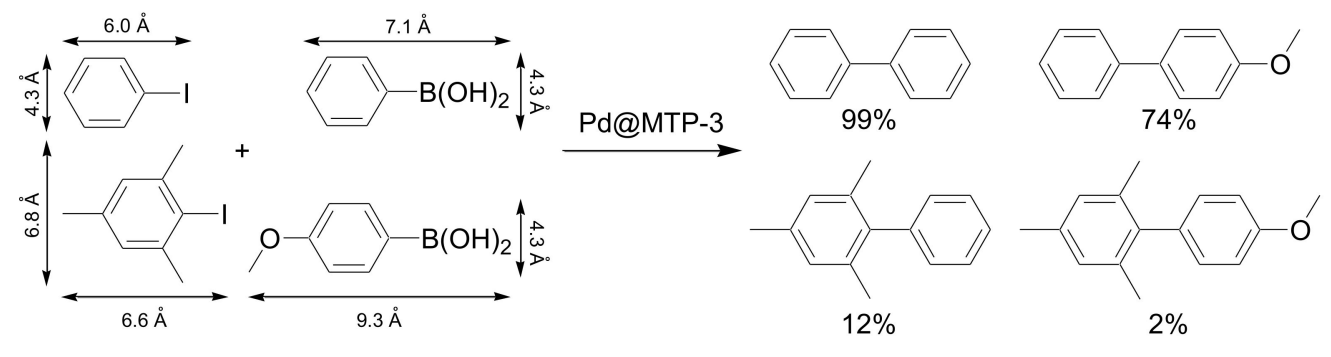

Scheme 15. Size-selective $\mathrm{C}-\mathrm{C}$ coupling reactions catalyzed by microporous polymer stabilized $\mathrm{Pd}$ NPs. Reproduced from [162], ACS: 2021.

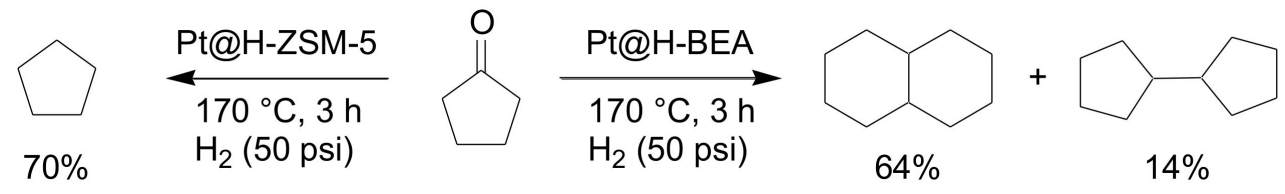

Scheme 16. Product selectivity controlled by pore size of zeolite-encapsulated Pt NPs. Reproduced from [163], ACS: 2020. 


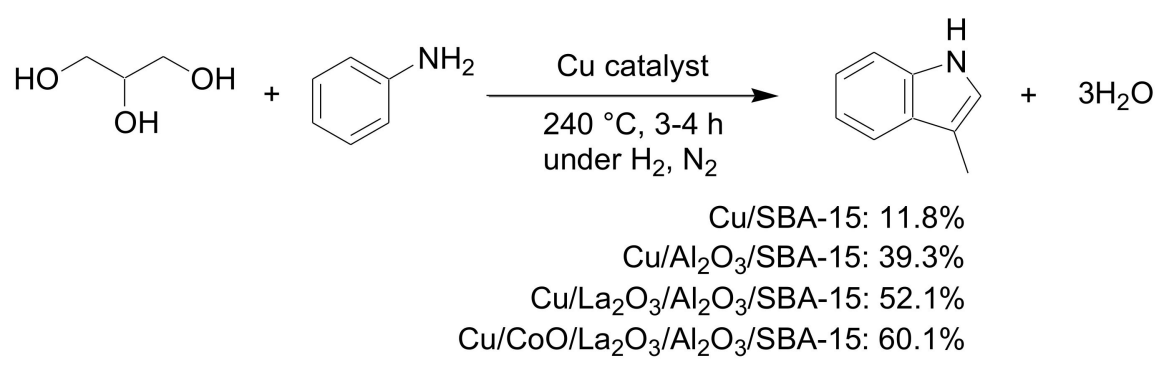

Scheme 17. Selective synthesis of 3-methylindole from the reaction of glycerin with aniline. Reproduced from [164], Springer: 2021.

\subsection{Organic-Inorganic Composites}

One of the most useful methods to obtain the inorganic materials with excellent properties as a support for metal NPs is functionalization of inorganic materials with organic molecules. On the other hand, metal-organic frameworks (MOFs), which includes a typical organic-inorganic composite, have attracted extensive attention as supports for metal NPs due to their huge surface area, large porosity, recyclability, and tunable functionality. Many kinds of metal NPs immobilized on the functionalized inorganic materials and MOFs have been reported until now [165-187].

Malta et al. synthesized the hydroxypropylated $\alpha-, \beta-$, or $\gamma$-cyclodextrins-stabilized Pd NPs supported on ceria, and compared the reactivity in Suzuki-Miyaura coupling reactions. The catalysts based on $\beta$ - and $\gamma$-cyclodextrins-stabilized Pd NPs showed higher reactivities than $\alpha$-cyclodextrins-stabilized Pd NPs, probably due to a higher degree of particles up to $5 \mathrm{~nm}$ [188]. A Suzuki-Miyaura coupling reaction took place smoothly at room temperature using thiourea-bridged periodic mesoporous organosilica and supported Pd NPs as a catalyst [189]. Ha et al. synthesized dual (temperature and pH)-responsive poly( $N$-isopropyl acrylamide-co-methacrylic acid) functionalized SBA-15. This material supported the fact that Pd NPs showed high catalytic activity for Suzuki-Miyaura coupling reactions at room temperature, while the activity decreased at higher temperature than LCST of PNIPAM [190]. It has been reported that Suzuki-Miyaura coupling reaction proceeded at room temperature using Pd NPs stabilized on CaAl-layered double hydroxide functionalized with tris(hydroxymethyl)aminomethane (Scheme 18) [191].

$$
\begin{aligned}
& \mathrm{Ar}-\mathrm{X}+\mathrm{Ph}-\mathrm{B}(\mathrm{OH})_{2} \underset{\mathrm{H}_{2} \mathrm{O} / \mathrm{EtOH}, \mathrm{K}_{2} \mathrm{CO}_{3},}{\stackrel{\mathrm{LDH} / \mathrm{Tris} / \mathrm{Pd}}{\longrightarrow}} \mathrm{Ar}-\mathrm{Ph} \\
& \mathrm{X}=\mathrm{I}, \mathrm{Br}, \mathrm{Cl} \quad \mathrm{rt}, 10-150 \text { min } 14 \text { examples } \\
& 60-99 \% \text { yield }
\end{aligned}
$$

Scheme 18. The Suzuki-Miyaura cross-coupling reaction at room temperature catalyzed by LDH/Tris/Pd. Reproduced from [191], Elsevier: 2018.

Pd NPs stabilized on 12-tungstophosphoric acid modified zirconia catalyzed the Suzuki-Miyaura coupling reaction efficiently and TOF reached to ca.100000 $\mathrm{h}^{-1}$ [192]. Pd NPs decorated into a biguanidine modified-KIT-5 showed high catalytic activity for SuzukiMiyaura coupling reaction under sonication at room temperature. The coupling product was obtained efficiently within 15 min [193]. Pd NPs immobilized on zirconium phosphate glycine diphosphonate nanosheets was confirmed to be an effective catalyst for SuzukiMiyaura and Mizoroki-Heck reaction, and was applicable to the flow system [194]. Pd NPs supported on the hybrid nanomaterials based on thiol functionalized halloysite nanotubes and highly cross-linked imidazolium salts showed high performance in Suzuki-Miyaura and Mizoroki-Heck coupling reactions, and TOF of $3.88 \times 10^{6} \mathrm{~h}^{-1}$ was achieved in SuzukiMiyaura coupling reaction [195]. Control synthesis of polyacrylamide brushes grafted onto silica particles ( $\mathrm{SiO}_{2}-g$-PAAm), which can be used for the support of Pd NPs was achieved using reversible addition-fragmentation chain transfer (RAFT) polymerization. Appropriate activity and recyclability of $\mathrm{SiO}_{2}-\mathrm{g}$-PAAm-Pd indicated in the Mizoroki-Heck coupling reaction of iodobenzene with $n$-butyl acrylate [196]. In Ullmann-type aryl iodides 
homocoupling, Au and Pd NPs loaded on ZIF-8 have been confirmed to be more efficient than the catalyst after calcination [197]. Kobayashi et al. developed poly(dimethyl)silaneimmobilized metal NPs with alumina as a second support, and the resulting catalysts have been utilized in several reactions (Schemes 19 and 20) [198,199].

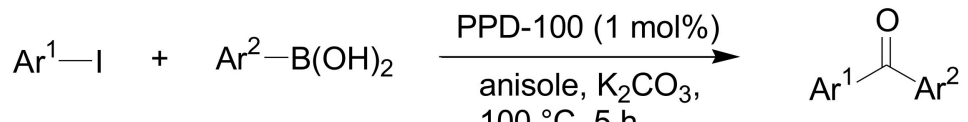

$$
\begin{aligned}
& 100^{\circ} \mathrm{C}, 5 \mathrm{~h} \quad 9 \text { examples } \\
& \text { CO balloon } \quad 64-97 \% \text { yield }
\end{aligned}
$$

Scheme 19. The carbonylative Suzuki-Miyaura coupling reactions catalyzed by polysilane $/ \mathrm{Al}_{2} \mathrm{O}_{3}$ immobilized Pd NPs. Reproduced from [198], Thieme: 2021.

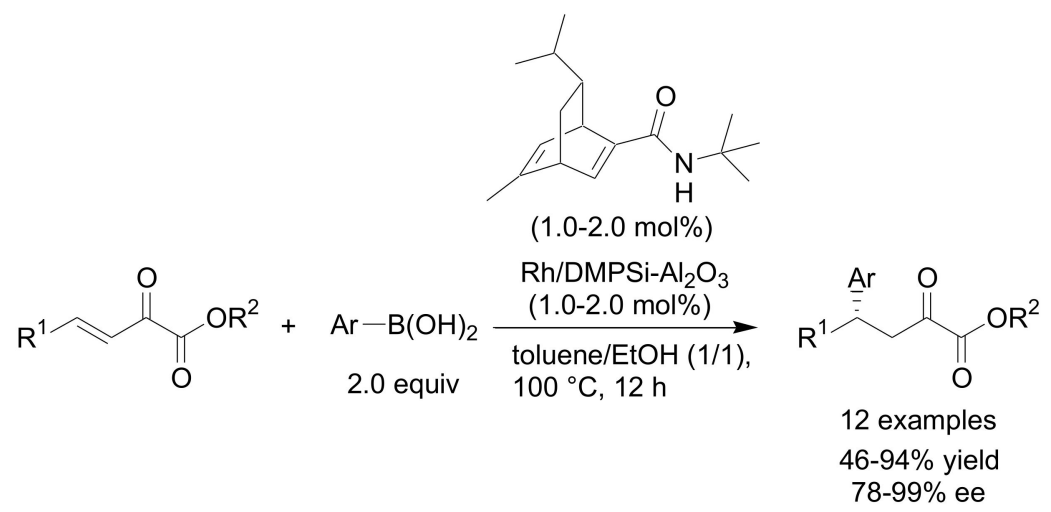

Scheme 20. Asymmetric 1,4-addition of arylboronic acids to $\beta, \gamma$-unsaturated $\alpha$-ketoesters. Reproduced from [199], Wiley-VCH: 2020.

A one-pot synthesis of benzo[c]pyrazolo[1,2-a]cinnoline-1-ones was achieved with Pd NPs dispersed on octakis[3-(3-aminopropyltriethoxysilane)propyl]octasilsesquioxane functionalized fibrous nanosilica (KCC-1) (Scheme 21) [200]. Thiocarbamide-functionalized graphene oxide-supported RhPd NPs have been tried for the Knoevenagel condensation of malononitrile and aryl aldehydes and showed an excellent catalytic activity to give the product within $35 \mathrm{~min}$ at room temperature (Scheme 22) [201].

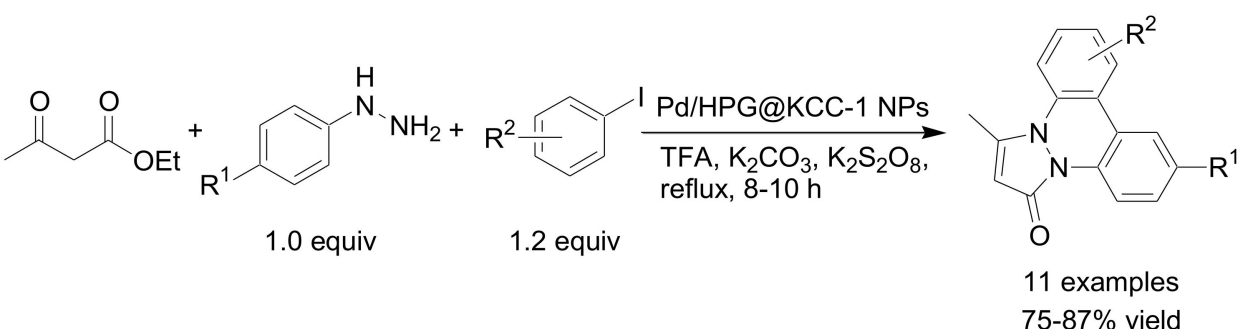

Scheme 21. Synthesis of benzo[c]pyrazolo[1,2-a]cinnoline-1-ones in the presence of Pd/HPG@KCC-1. Reproduced from [200], RSC: 2017.

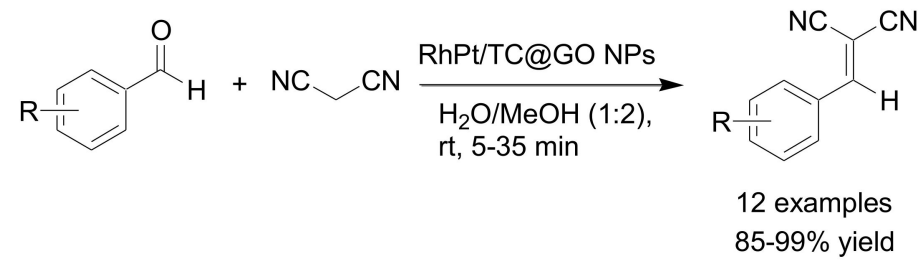

Scheme 22. Knoevenagel condensation at room temperature catalyzed by Rh-Pt NPs. Reproduced from [201], Elsevier: 2018. 
Parida et al. reported that amino-functionalized $\mathrm{Zr}$-based MOF (UiO-66- $\mathrm{NH}_{2}$ ) was a suitable photocatalyst and support for metal NPs because it has a high surface area, tunable pores, and high thermal and chemical stabilities [202]. The same research group also investigated the utility of a graphene oxide/ZnCr-layered double hydroxide hybrid nanocomposite [203]. Chen and Wang et al. found that the porous coordination frameworks (PCFs) using the DIB-TETA as organic linkers and inorganic NPs as nodes exhibited superior photocatalytic performances in a noble metal-free Suzuki-Miyaura coupling reaction [204].

\subsection{Carbon Materials}

Charcoal is a classic commercial support for catalysts. Carbon materials have been proven to be suitable supports for heterogeneous catalysis, due to high thermal and chemical stability, their special electronic properties, and tunable textural properties such as surface area, porosity, and surface chemistry. To date, numerous kinds of metal NPs supported on carbon materials such as graphene and carbon nanotubes have been developed [205-231].

Ni@Pd core-shell NPs on carbon nanotubes (CNT) have been reported to show a high catalytic activity for carbonylative Suzuki-Miyaura cross-coupling reactions. The immobilization of the Ni@Pd NPs on CNT not only prevented their aggregation, but also significantly enhanced the accessibility of the catalytically active sites [232]. Hajipour and Farrokhpour et al. achieved the immobilization of Co NPs within a carbon nanotube channel, and found that Co NPs-in-CNTs, as compared to Co NPs-out-CNTs, exhibited excellent activity for Mizoroki-Heck reactions (Scheme 23) [233]. Chung et al. decorated Rh NPs on fullerene C60 to obtain a highly efficient nanocatalyst for Suzuki-Miyaura coupling reactions [234]. Chen and Li et al. designed an electron-deficient Au NPs-based catalyst via Schottky contact with boron-doped carbons for room temperature Stille coupling reaction. The electron-deficiency of Au NPs significantly increased the activation of C-Br bonds in alkylbromides and successive coupling reaction with allylstannanes [235].

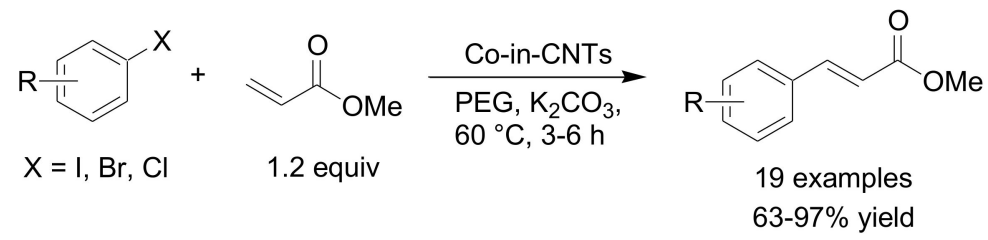

Scheme 23. Heck reaction with carbon-nanotube-encapsulated Co NPs. Reproduced from [233], RSC: 2019.

Astruc et al. successfully immobilized $\alpha-\mathrm{Fe}_{2} \mathrm{O}_{3}$ nanocluster on graphene oxide (GO) by utilizing the supramolecular interaction between amphiphilic tris(triazolyl)-polyethylene glycol and GO. $\alpha-\mathrm{Fe}_{2} \mathrm{O}_{3} / \mathrm{GO}$ worked well as a catalyst for Suzuki-Miyaura coupling reaction with only parts-per-million loading [236]. Taniike et al. revealed that a graphene oxide framework prepared with benzene 1,4-diboronic acid as a two-side linker was a superior support of Pd NPs to that with phenylboronic acid as a one side linker [237].

The coupling reaction of aryl chlorides can be achieved by using reduced graphene oxide-supported Pd NPs. The size of NPs and reactivity was dependent on the preparation temperature, and this catalyst was applied for the synthesis of key intermediates of important Sartans and Fluxapyroxad medicines (Scheme 24) [238]. Hoseini et al. utilized self-assembly at the toluene-water interface to produce a PdNiZn nanosheet and PdNiZn/reduced graphene oxide (rGO) ultrathin spherical NPs. The presence of rGO enhanced the catalytic activity, probably due to altering the electronic properties [239]. Ni NPs supported reduced graphene oxide, which has also been prepared by the hydrothermal process and investigated the catalytic activity for the homocoupling of arylboronic acids and alkynes [240]. Graphene acid is a convenient platform for the surface anchoring of Pd NPs with a narrow and sharp distribution. The size of NPs can be easily con- 
trolled by the amount of the Pd precursor, and the catalyst showed a high activity in the Suzuki-Miyaura coupling reaction and oxidative homocoupling of arylboronic acids under environmentally friendly conditions [241]. Three-dimensional graphene, which has excellent properties such as ultrahigh surface-to-volume ratio, high porosity, low density, etc., was used for the effective support of Au NPs and PdCo-bimetallic NPs [242,243].
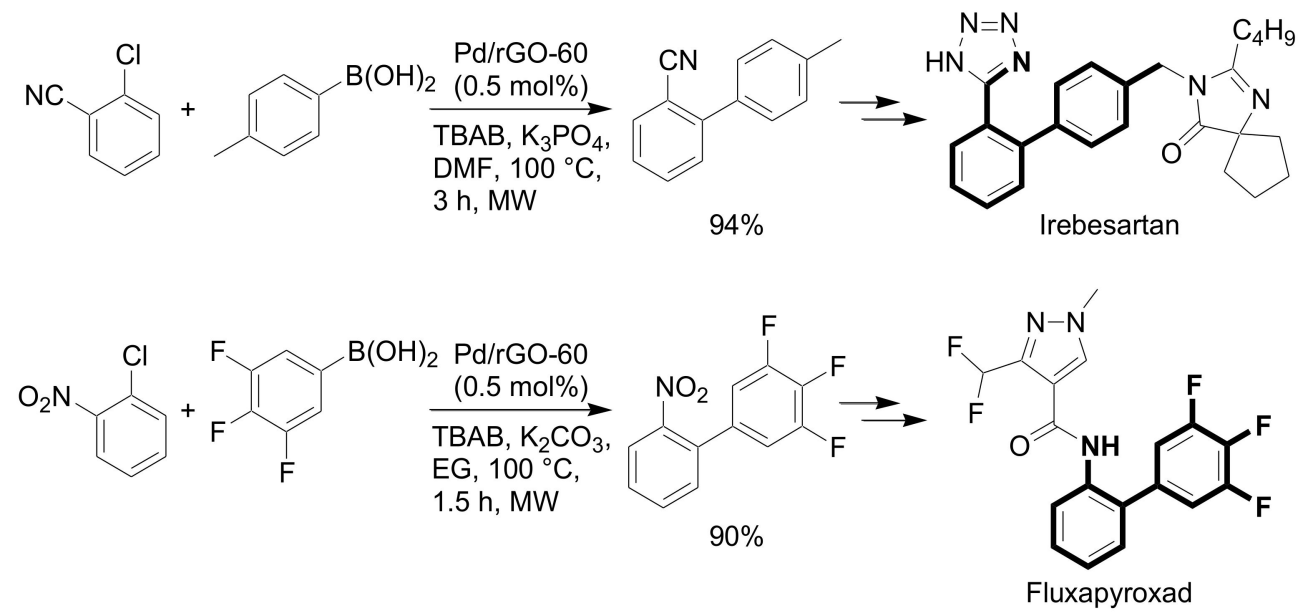

Scheme 24. The synthesis of the intermediate of Sartans and Fluxapyroxad. Reproduced from [238], RSC: 2020.

C-methylations of alcohol, ketones, and indoles have been achieved using methanol and $\mathrm{Pt} / \mathrm{C}$ as a sustainable $\mathrm{C} 1$ source and a catalyst, respectively. The reaction is driven by a borrowing-hydrogen mechanism (Scheme 25) [244]. Nitrogen-doped carbon-encapsulated $\mathrm{Ni} / \mathrm{Co}$ NPs catalyzed pinacol couplings have been reported. The reaction mechanism is different to the classical pinacol coupling pathway, and the initial formation of silyl radicals is proposed (Scheme 26) [245].

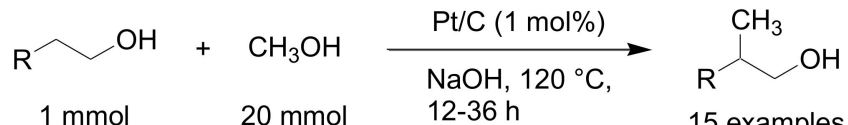

$$
\begin{aligned}
& \text { 73-92\% yield }
\end{aligned}
$$

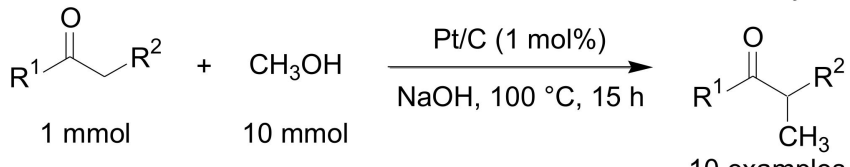

$$
\begin{aligned}
& 10 \text { examples } \\
& 85-96 \% \text { yield } \\
& \underset{1 \mathrm{mmol}}{\stackrel{\mathrm{O}}{\mathrm{N}}}+\underset{10 \mathrm{mmol}}{\mathrm{CH}_{3} \mathrm{OH}} \underset{\mathrm{NaOH}, 100^{\circ} \mathrm{C}, 15 \mathrm{~h}}{\stackrel{\mathrm{Pt} / \mathrm{C}(1 \mathrm{~mol} \%)}{\longrightarrow}} \\
& \mathrm{R}_{\mathrm{CH}_{3}}^{\mathrm{O}} \mathrm{CH}_{3} \text { or } \mathrm{R}^{\stackrel{\mathrm{O}}{\mathrm{I}}} \mathrm{CH}_{3} \\
& 6 \text { examples } \\
& 79-98 \% \text { yield }
\end{aligned}
$$
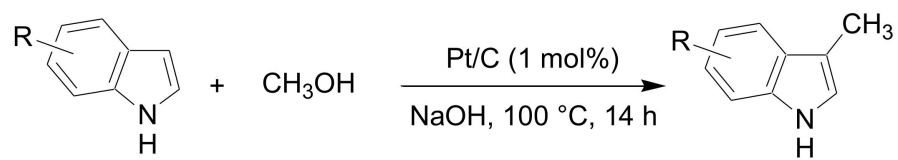

Scheme 25. C-methylation of alcohols, ketones, and indoles with methanol as a C1 source. Reproduced from [244], ACS: 2018. 


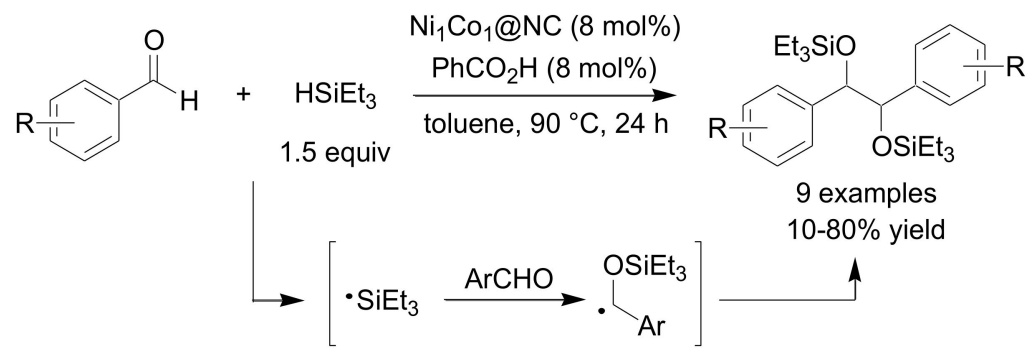

Scheme 26. Silylative Pinacol coupling. Reproduced from [245], ACS: 2018.

Graphitic carbon nitride-supported Pd NPs $\left(g-\mathrm{C}_{3} \mathrm{~N}_{4} / \mathrm{Pd}\right)$ is an efficient photocatalyst for Suzuki-Miyaura cross-coupling reactions. It has been confirmed that the reaction is driven by the light because the conversion of iodobenzene has the same trend as the absorption of light by the $g-\mathrm{C}_{3} \mathrm{~N}_{4} / \mathrm{Pd}$ [246]. Dabiri et al. prepared AuPd alloy NPs immobilized on graphitic carbon nitride sheets, which enhanced Suzuki-Miyaura crosscoupling reactions at room temperature under visible-light irradiation. The photocatalytic activities strongly depend on the $\mathrm{Au}: \mathrm{Pd}$ ratio of the alloy NPs. The activity of $\mathrm{Au}_{1} \mathrm{Pd}_{1} / g$ $\mathrm{C}_{3} \mathrm{~N}_{4}$ was much higher than that of the catalysts, compared with other Au:Pd ratios, probably because the electron transfer between the two metals occurs efficiently in the alloy NPs with an Au:Pd weight ratio near 1:1 (Scheme 27) [247]. Lim et al. investigated the role of the graphene interface in the photocatalyst, and found that the fast electron transfer was achieved in the presence of the reduced graphene oxide layer. Consequently, the highest catalytic activity for the visible-light induced $\mathrm{C}-\mathrm{C}$ coupling reaction was obtained with Pd-nanodot-modified reduced GO-coated Au NPs [248].

$$
\begin{aligned}
& \mathrm{Ph}-\mathrm{I}+\mathrm{Ph}-\mathrm{B}(\mathrm{OH})_{2} \underset{\substack{\mathrm{H}_{2} \mathrm{O} / \mathrm{EtOH}(1: 1), \mathrm{K}_{3} \mathrm{PO}_{4}, \\
\text { visible light, rt, } 30 \mathrm{~min}}}{\longrightarrow} \mathrm{Ph}-\mathrm{Ph} \\
& \mathrm{Pd} / g-\mathrm{C}_{3} \mathrm{~N}_{4}: 31 \% \\
& \mathrm{Au} / \mathrm{g}-\mathrm{C}_{3} \mathrm{~N}_{4}: \text { trace } \\
& \mathrm{Au}_{1} \mathrm{Pd}_{2} / g-\mathrm{C}_{3} \mathrm{~N}_{4}: 91 \% \\
& \mathrm{Au}_{1} \mathrm{Pd}_{1} / g-\mathrm{C}_{3} \mathrm{~N}_{4}: 99 \% \\
& \mathrm{Au}_{2} \mathrm{Pd}_{1} / g-\mathrm{C}_{3} \mathrm{~N}_{4}: 29 \% \\
& \mathrm{Ar}-\mathrm{X}+\mathrm{Ph}-\mathrm{B}(\mathrm{OH})_{2} \underset{\mathrm{H}_{2} \mathrm{O} / \mathrm{EtOH}(1: 1), \mathrm{K}_{3} \mathrm{PO}_{4}}{\longrightarrow} \mathrm{Ar}-\mathrm{Ph} \\
& \mathrm{X}=\mathrm{I}, \mathrm{Br}, \mathrm{Cl} \quad \text { visible light, } \mathrm{rt}, 0.5-2 \mathrm{~h}, 12 \text { examples } \\
& 39-99 \% \text { yield }
\end{aligned}
$$

Scheme 27. Visible-light-enhanced Suzuki-Miyaura cross-coupling reactions. Reproduced from [247], Elsevier: 2020.

\subsection{Organic Polymers and Surfactants}

Polymers such as poly(vinylpyrrolidone) (PVP) and surfactants including quaternary ammonium salt with a long alkyl chain are commonly used as stabilizers in the synthesis of metal NPs. For example, Rampino et al. used poly(vinyl alcohol) (PVA) to protect Pd and Pt NPs in 1941, and El-Sayed et al. initially reported the use of Pd nanoparticles stabilized by PVP as catalysts in the Suzuki-Miyaura coupling reaction of aryl iodides with arylboronic acids in aqueous media $[1,249]$. Dendrimers are also often utilized as the stabilizer for metal NPs, and pioneering studies were reported by Crook, Tomalia, and Esumi [250-252]. On the other hand, as a greener process, phytosynthesis that utilizes parts of whole plants to synthesize metal NPs is also under exploitation and is an advantageous and profitable approach [253]. Numerous kinds of metal NPs stabilized by organic compounds with a high molecular weight have been reported [254-294].

Peinemann et al. prepared Pd NPs with a subnanometer size $(<1 \mathrm{~nm})$ supported within the highly cross-linked network, which catalyzed Suzuki-Miyaura coupling reactions at a low temperature $\left(<40{ }^{\circ} \mathrm{C}\right)$ [295]. Pd NPs stabilized by heteroatom donor-decorated 
polymer immobilized ionic liquid catalyzes the Suzuki-Miyaura coupling reaction of aryl bromides with remarkable efficacy in aqueous media under exceptionally mild conditions. Improvements in catalyst performance arising from the introduction of PEG are attributed to an increase in dispersibility and/or solubility, facilitating access to more exposed active sites [296]. The room temperature Suzuki-Miyaura coupling reactions have been confirmed in the presence of Pd NPs supported by polydopamine and Pd NPs synthesized using Sapindus mukorossi seed extract $[297,298]$. Studer et al. prepared Pd NPs by visible light irradiation to the DMF solution of silyl ketones and $\mathrm{Pd}(\mathrm{OAc})_{2}$. The diameter of $\mathrm{Pd} \mathrm{NPs}$ could be adjusted to 1.9 to $5.2 \mathrm{~nm}$ depending on the photoinitiator used (Scheme 28) [299]. Pd NPs stabilized on poly ( 0 -aminothiophenol) prepared by oxidation polymerization of $o$-aminothiophenol in the presence of $\mathrm{Pd}\left(\mathrm{NO}_{3}\right)_{2}$ showed a high catalytic activity for the Suzuki-Miyaura coupling reaction of aryl chloride in water [300]. The amphiphilic property of the eumelanin support helps Pd NPs to catalyze the Suzuki-Miyaura coupling reaction in water through a hydrophobic effect [301]. A series of $\mathrm{Pd}_{\mathrm{x}} \mathrm{M}_{147-\mathrm{x}}(\mathrm{M}=\mathrm{Cu}, \mathrm{Pt}, \mathrm{Au}, \mathrm{Rh}, \mathrm{Ru})$ stabilized on poly(amidoamine) dendrimers were synthesized and their catalytic activities were investigated in Suzuki-Miyaura coupling reactions. $\mathrm{Pd}_{74} \mathrm{Cu}_{73}$ DEN showed a similar activity to $\mathrm{Pd}_{147} \mathrm{DEN}$ and DFT calculations illustrated that the similar activity of the $\operatorname{Pd}_{147}$ and $\mathrm{Pd}_{74} \mathrm{Cu}_{73}$ DENs originate from the comparable energy barriers of the rate-determining steps [302].

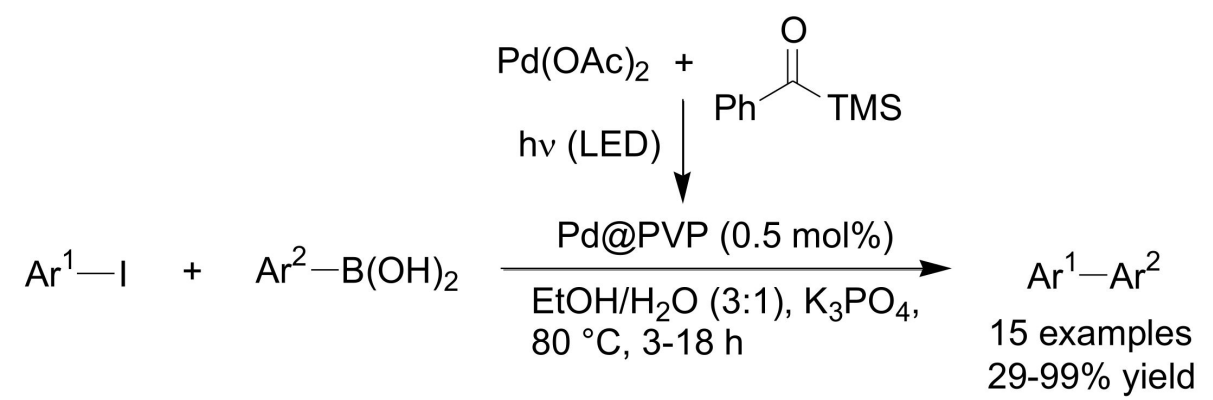

Scheme 28. The catalytic activity of Pd NPs prepared under visible light irradiation. Reproduced from [299], ACS: 2018.

Thang et al. developed the facile preparation method of polymer-metal nanocomposites for an improved catalytic performance by utilizing ultrasound as both the initiation and reducing source. Metal NPs were immobilized on the hydrophilic shell of the polymer matrix, and the size of the NPs were closely related to the ratio of tertiary amine groups in the polymer matrix to metal atoms [303]. Highly efficient Tsuji-Trost allylations in water have been achieved using Pd NPs stabilized by PVP. A very high TON of 537,000 was obtained in this system [304]. Yu et al. obtained the effective catalysts, which showed high activity for carbonylative Sonogashira coupling reactions by the introduction of salen moieties into highly cross-linked polyacrylamide [305]. Pd NPs were encapsulated within hybrid hydrogels made from an acylhydrazide-functionalized 1,3:2,4-dibenzylidene sorbitol (DBS$\mathrm{CONHNH}_{2}$ ) low-molecular-weight gelator combined with agarose polymer gelator via an in situ reduction of $\mathrm{Pd}(\mathrm{II})$. These heterogeneous gel-phase catalysts were successfully applied for several C-C coupling reactions (Scheme 29) [306-308]. Simple hydrophobic polymers without a coordination site such as polystyrene and poly(tetrafluoroethylene) have been confirmed to stabilize metal NPs and polymer-supported metal NPs were applicable to the recyclable catalyst for several reactions in water [309-313]. 


$$
\begin{aligned}
& \begin{array}{ccc}
\mathrm{Ar}-\mathrm{I}+\mathrm{Ph}-\mathrm{B}(\mathrm{OH})_{2} \underset{\mathrm{EtOH} / \mathrm{H}_{2} \mathrm{O}(3: 1),}{\mathrm{Pd}-\mathrm{Gel}} & \mathrm{Ar}-\mathrm{Ph} \\
& \mathrm{K}_{2} \mathrm{CO}_{3}, 50{ }^{\circ} \mathrm{C}, 18 \mathrm{~h} & 11 \text { examples } \\
& 69-100 \% \text { yield }
\end{array}
\end{aligned}
$$

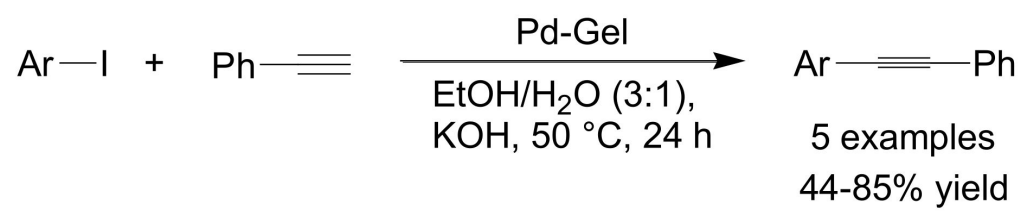

Scheme 29. Pd NPs@hybrid hydrogels catalyzed C-C coupling reactions. Reproduced from [307], Elsevier: 2020, and [308], RSC: 2018.

Oble and Rieger et al. synthesized a nanostructured well-defined core-shell nanogel with the ability to stabilize Pd NPs in its core by using reversible addition-fragmentation chain-transfer (RAFT)-mediated aqueous dispersion polymerization [314]. One of the most effective catalytic systems is micellar catalytic systems, which have been developed and expanded by Lipshutz and Handa groups. In their reaction systems, several reactions proceed at room temperature by designing an appropriate surfactant which form a micellar reaction field in water (Scheme 30) [315-328].

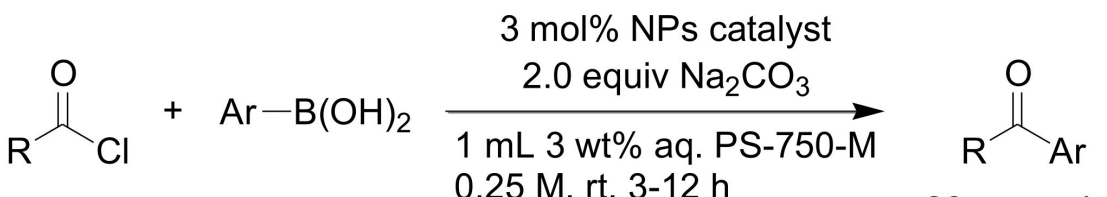

$$
\begin{aligned}
& 0.25 \mathrm{M}, \mathrm{rt}, 3-12 \mathrm{~h} \quad 28 \text { examples } \\
& 50-92 \% \text { yield } \\
& \mathrm{Ar}^{1}-\mathrm{X}+\mathrm{Ar}^{2}-\mathrm{B}(\mathrm{OH})_{2} \underset{1 \mathrm{~mL} 3 \text { wt } \% \text { aq. } \mathrm{PS}-750-\mathrm{M}}{\stackrel{2.0 \text { equiv } \mathrm{K}_{3} \mathrm{PO}_{4} \cdot \mathrm{H}_{2} \mathrm{O}}{\longrightarrow}} \mathrm{Ar}^{1}-\mathrm{Ar}^{2} \\
& 0.25 \mathrm{M}, 60^{\circ} \mathrm{C}, 11-18 \mathrm{~h}
\end{aligned}
$$

\section{0 examples}

Scheme 30. One example of an efficient coupling reaction by micellar catalysts. Reproduced from [316], ACS: 2021.

Yang and Jiang et al. reported a $\mathrm{Cu}$ NPs-catalyzed substrate-dependent chemodivergent transformation of vinyl azides with a terminal alkyne. 2,5-Disubstituted pyrroles were selectively obtained with aryl and aliphatic alkynes, whereas silylated alkynes afforded 2,3,4-trisubstituted pyrroles (Scheme 31) [329]. Substrate-dependent chemodivergent was also observed in the reaction of substituted benzyl bromides with terminal alkynes catalyzed by $\mathrm{CuN}_{3}$ NPs. The electron donating group containing terminal alkyne produced 5-alkynyl 1,4-disubstituted triazoles whereas for alkynes with terminal electron withdrawing group facilitated the formation of 1,4-disubstituted triazoles (Scheme 32) [330]. The synthesis of 3-substituted isocoumarins from 2-chlorobenzoic acids and 1,3-diketones have been achieved utilizing $\mathrm{Cu}$ NPs. When 2-bromo- $\mathrm{N}$-phenylbenzamide was used as a substrate, the reaction completed within 15 min (Scheme 33) [331]. Metal NPs can be applicable for the multi steps reactions. For example, Abdolmohammadi et al. reported the synthesis of [1]benzopyrano[b]pyridine-3-carbonitriles though Knoevenagel condensation, Michael addition, cyclization, tautomerization, and aromatization (Scheme 34) [332]. Trzeciak et al. have developed DNA-stabilized metal NPs and reported their catalytic applications in several $\mathrm{C}-\mathrm{C}$ bond forming reactions such as Suzuki-Miyaura, carbonylative Sonogashira, and hydroformylation [333-337]. 
<smiles>[R]C#Cc1c(-c2ccccc2)c[nH]c1-c1ccccc1</smiles>

9 examples

$50-82 \%$ yield

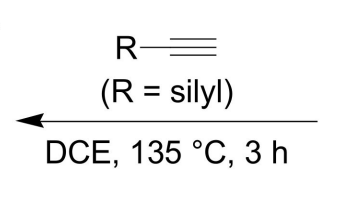

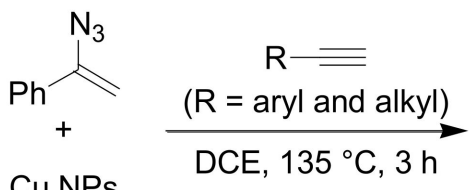

Cu NPs
$\overbrace{N^{N}} \int_{P h}$

33 examples $13-83 \%$ yield

Scheme 31. Switchable reactivity between vinyl azides and terminal alkynes. Reproduced from [329], ACS: 2019

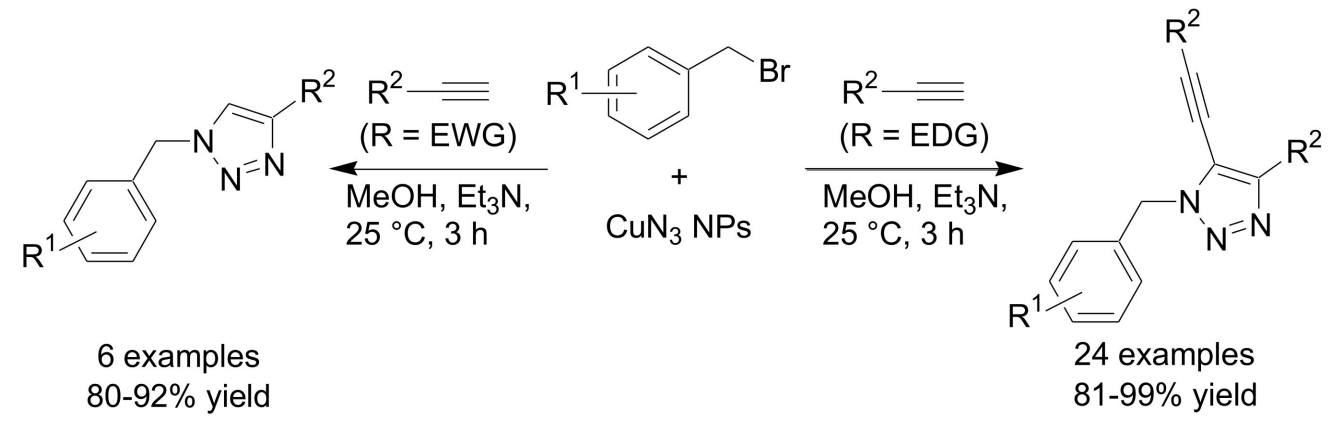

Scheme 32. Alkyne-dependent synthesis of 1,2,3-triazole derivatives. Reproduced from [330], Nature Research: 2020.

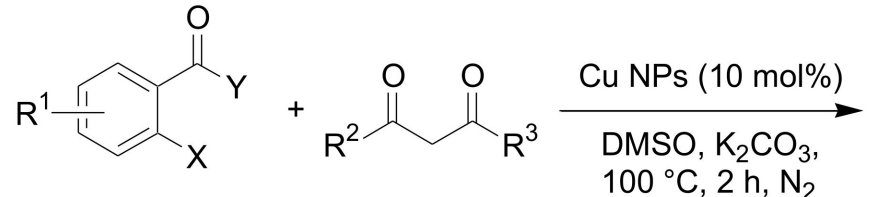$$
\mathrm{X}=\mathrm{Cl}, \mathrm{Br}
$$$$
100{ }^{\circ} \mathrm{C}, 2 \mathrm{~h}, \mathrm{~N}_{2}
$$<smiles>[R][R]c1ccc2cc([R])oc(=O)c2c1</smiles>

26 examples $18-95 \%$ yield

Scheme 33. One-pot synthesis of isocoumarin derivatives. Reproduced from [331], Elsevier: 2017.

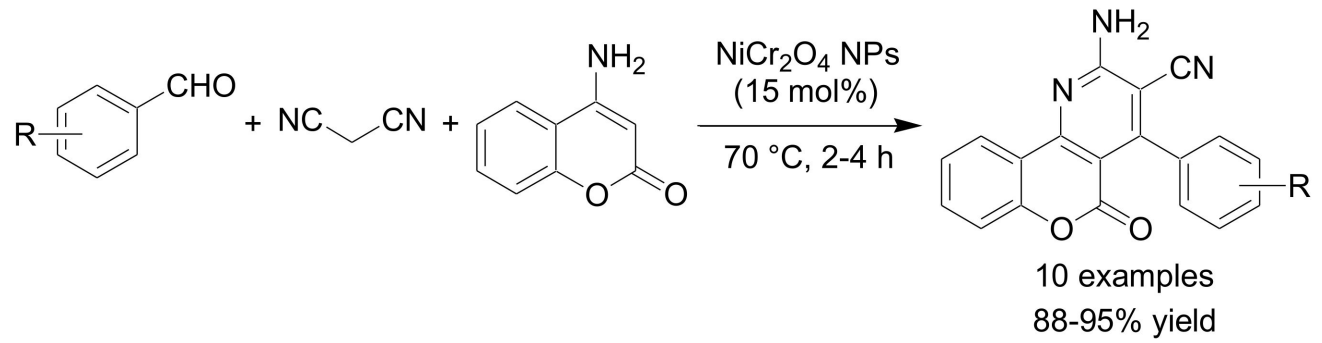

Scheme 34. One-pot synthesis of [1]benzopyrano[b]pyridin-3-carbonitrile derivatives. Reproduced from [332], Taylo\&Francis: 2020.

Bhalla et al. found that Supramolecular polymer of perylene bisimide derivative and $\mathrm{ZnO}$ NPs exhibited remarkable efficiency in direct dehydrogenative cross-coupling between terminal alkynes and aldehydes for the synthesis of ynones under visible light irradiation (Scheme 35) [338]. They also found that thiophene appended perylene bisimide derivative undergoes oxidative polymerization in the presence of gold ion to generate supramolecular polymeric ensemble, which showed photocatalytic activity in MizorokiHeck reaction [339]. 


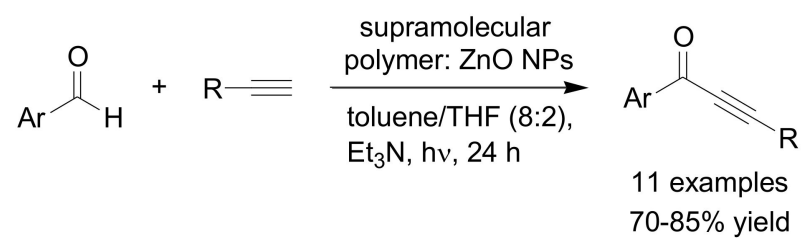

Scheme 35. One-pot synthesis of [1]benzopyrano[b]pyridin-3-carbonitrile derivatives. Reproduced from [338], RSC: 2018.

\subsection{Others}

As seen, the pioneering works of Reetz and Jeffery [2,340], organic molecules and simple tetraalkylammonium salts are also able to be used as stabilizers for metal NPs [341]. The use of ionic liquids alone as NP stabilizers and reaction media for the Suzuki-Miyaura coupling reaction was also shown to be efficient [342]. The introduction of nitrogen- and phosphorus-based molecules is also of special interest, because they not only act as a stabilizer of metal NPs, but also as ligands, which enhance the catalytic activity of metal NPs. The metal NPs stabilized by small molecules were used not only as prepared ones, but also as in situ generated ones [343-361].

TPPTS (triphenylphosphine-3, $3^{\prime}, 3^{\prime \prime}$-trisulfonic acid trisodium salt), which is one of the most well-known water-soluble phosphine ligands acted as not only as a stabilizer, but also as an activator for Pd NPs. Pd NPs/TPPTS catalyzed the Suzuki-Miyaura coupling reactions of aryl bromides at room temperature to afford the coupling product within $1 \mathrm{~h}$ [362]. In situ-generated Pd NPs by gallic acid was an extremely simple, green, and active catalyst, which catalyzed $C-C$ coupling reactions at room temperature $[363,364]$. Kumar et al. developed a selective synthesis of $\mathrm{Pd}_{9} \mathrm{Te}_{4}$ and PdTe, which are applicable for the catalyst in the Suzuki-Miyaura coupling reactions of aryl chloride [365]. By the same research group, a series of bidentate organochalcogen ligands ( $N, E ; E=S / S e)$ were synthesized and they investigated the applicability for the support of Pd NPs [366,367]. Sewald et al. confirmed that solvent-stabilized Pd NPs were applicable for bio-orthogonal side-chain derivatizations of amino acids [368]. In situ-generated Pd NP-catalyzed threecomponent coupling of chloromethylarene with allyltrimethoxysilane and carbon dioxide (i.e., a carboxylative Hiyama coupling reaction) successfully produced $\alpha, \beta$-unsaturated esters, whereas the coupling reaction with allytributylstannane (i.e., a carboxylative Stille coupling reaction) gave $\beta, \gamma$-unsaturated esters (Scheme 36) $[369,370]$.

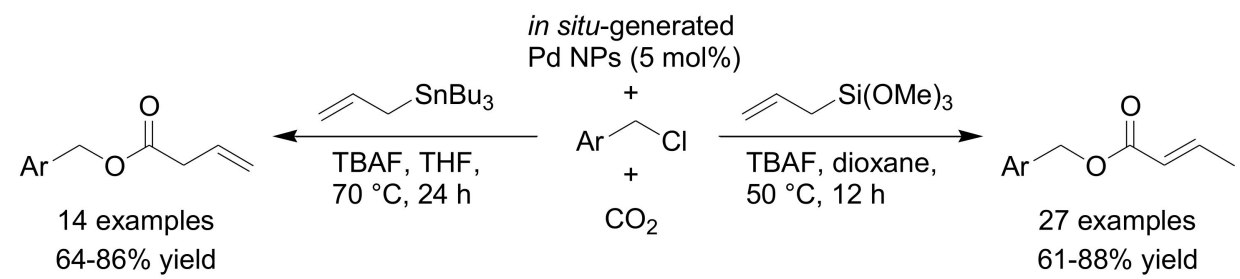

Scheme 36. The difference between carboxylative Stille coupling reaction and carboxylative Hiyama coupling reaction. Reproduced from [369], Wiley-VCH: 2017, and [370], ACS: 2013.

Sathish and Praveen et al. developed a supercritical processing method for the preparation of Au NPs, and found that the resultant Au NPs showed a high catalytic activity for Suzuki-Miyaura and Sonogashira coupling reactions [371]. The catalytic activity of $\mathrm{Co}_{3} \mathrm{O}_{4}$ in the Mizoroki-Heck reaction was confirmed by the Bagherzadeh group [372].

Tanaka et al. achieved the $\beta$-alkynylation of amides via $\mathrm{C}\left(\mathrm{sp}^{3}\right)$ - $\mathrm{H}$ activation using Pd NPs stabilized by bis[N,N'-(2-indalolyl)]-1,5-diazacyclooctane (Scheme 37) [373]. Wu et al. have established a cascade alkynylation and selective hydrogenation catalyzed by covalent binaphthyl-stabilized Pd NPs to provide a novel and highly efficient methodology for accessing $Z$ and Z,Z-selective phosphinyl [3]dendralenes [374]. Binaphthylstabilized Pd NPs were also utilized to synthesize diphenylallylidenemethylindolin-2-ones, indanone derivative, 3-allylidene-2(3H)-oxindoles, and 3-allylidene-2(3H)-benzofuranones 
(Scheme 38) [375-378]. Obora et al. found that Ir NPs showed excellent catalytic activity in $\beta$-(aryl)methylation of alcohol [379,380]. Feng, Wang, and Bao et al. developed an efficient method for the selective synthesis of $\delta$-lactone from the telomerization of 1,3-butadiene with $\mathrm{CO}_{2}$. This reaction was catalyzed by ultrasmall Pd NPs generated in situ [381]. Telmisartan-stabilized $\mathrm{Cu}$ NPs were utilized to synthesize naphtho[2,3-g]phthalazine derivatives as potential inhibitors of tyrosinase enzymes [382].

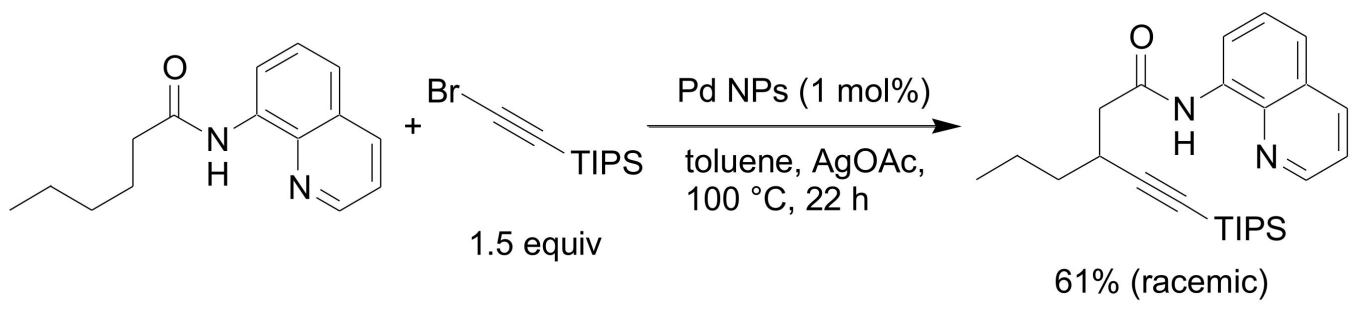

Scheme 37. C( $\left(\mathrm{sp}^{3}\right)-\mathrm{H}$ activation catalyzed by Pd NPs. Reproduced from [373], Thieme: 2018.
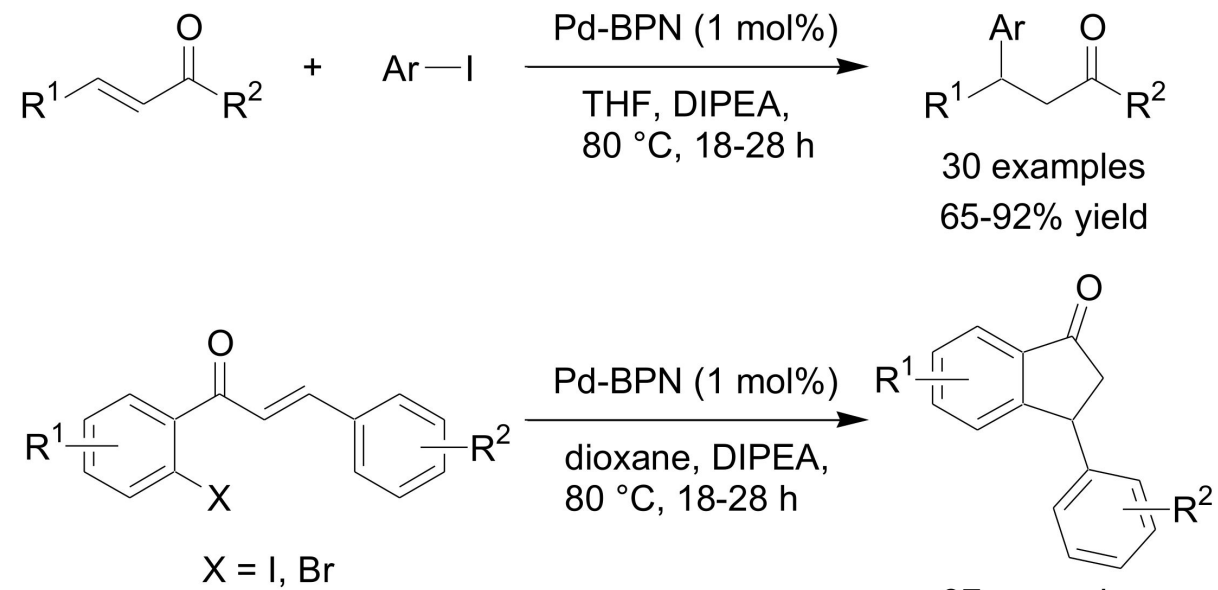

37 examples

$51-94 \%$ yield<smiles>[X]c1ccccc1[Y]C(=O)C#Cc1ccccc1</smiles>

$$
\begin{gathered}
X=I, B r \\
Y=N R, O
\end{gathered}
$$

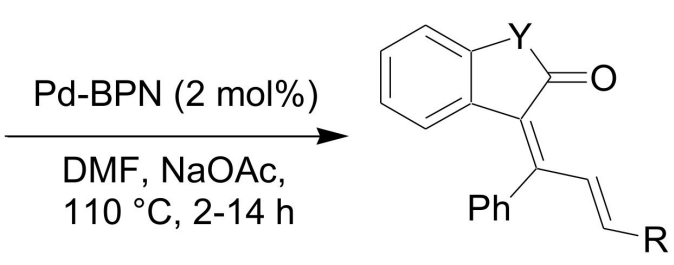

33 examples $60-98 \%$ yield

Scheme 38. Synthesis of indanone derivative, 3-allylidene-2(3H)-oxindoles, and 3-allylidene-2(3H)benzofuranones catalyzed by binaphthyl-stabilized Pd NPs. Reproduced from [376], ACS: 2020, and [377,378], Wiley-VCH: 2019,2017.

Ćirić-Marjanović et al. have reported the oxidative polymerization using $\mathrm{H}_{2} \mathrm{O}_{2} / \mathrm{Fe}_{3} \mathrm{O}_{4}$ NPs in an oxidant/catalyst system. Ammonium peroxydisulfate (APS) was used as an initiator in these systems $[383,384]$. Ultrahigh molecular weight poly(methyl methacrylate) was synthesized using 2-bromoisobutyric acid ethyl ester (EBiB) in the presence of Pd NPs. The polymerization was initiated by the radicals produced from the reaction of $\mathrm{EBiB}$ with Pd NPs [385].

Galian, Lloret-Fillol, and Pérez-Prieto et al. found that colloidal CsPdBr 3 perovskite NPs are suitable as photosensitizers for photoredox catalytic homo- and cross-coupling of benzyl bromides at room temperature with TON up to 17500 (Scheme 39) [386]. 


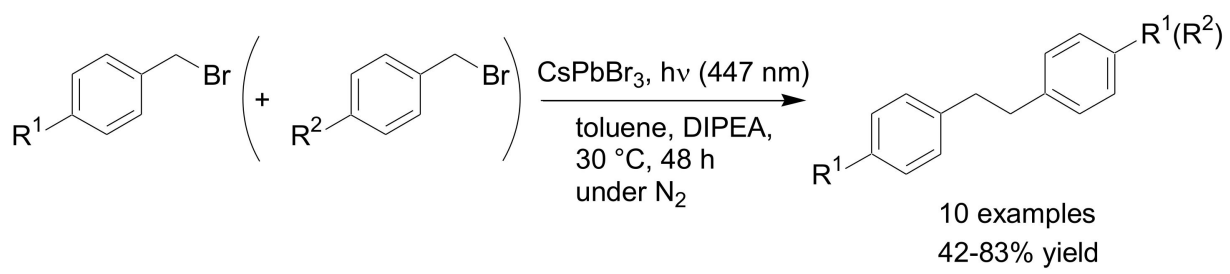

Scheme 39. Homo- and cross-coupling of benzyl bromides catalyzed by $\mathrm{CsPbBr}_{3}$ perovskite. Reproduced from [386], RSC: 2020.

\section{Conclusions and Perspective}

$\mathrm{C}-\mathrm{C}$ bond forming reactions have been widely utilized to synthesize many kinds of functional molecules such as biomaterials and natural products, fine chemicals, and medicines. On a small scale, these reactions are generally taken place with homogeneous catalysts utilizing the eminent advantages of high activity and selectivity. However, the homogeneous catalysts are not generally appropriate for industrialization because of their problems encountered in higher cost, stability, separation, and reusability. On the other hand, recyclable heterogeneous catalysts have some disadvantages, such as low activity and selectivity, the requirement of severe reaction conditions, and the leaching of metal species.

Metal NPs are expected to improve the above limits in industrialization. This review has outlined recent advances in metal NPs, which were used in the $\mathrm{C}-\mathrm{C}$ bond forming reactions. Many types of support, such as inorganic materials, magnetically recoverable materials, porous materials, organic-inorganic composites, carbon materials, polymers and surfactants have been utilized to develop the metal NP catalysts. In each support, the excellent metal NPs which proceeded the $\mathrm{C}-\mathrm{C}$ bond forming reactions, even at room temperature, or showed the photocatalytic activity, have been developed. In addition, most of them showed a high recyclability, and metal NP-catalyzed regio- and stereoselective reactions have been also developed. However, most of the reactions outlined in this review have been performed with catalysts at a mole percent loading $(0.1 \mathrm{~mol} \%-10 \mathrm{~mol} \%)$. For industrial-scale applications, the use of an extremely low loading of catalysts is of great importance. For most catalysts (especially in the case of Pd NPs), the catalytic activity has been confirmed in well-known coupling reactions such as Suzuki-Miyaura, MizorokiHeck, Hiyama, Stille, Ullmann, and Sonogashira coupling reactions. In other words, new reactions catalyzed by metal NPs are not well developed. Considerable efforts over the last few decades have led to the development of metal NP catalysts which overcome various drawbacks such as reactivity and reusability. I hope that metal NPs will make a significant contribution to industry in the near future by further developments such as the metal NPs with a reactivity and selectivity that surpasses those of homogeneous catalysts, the new reaction peculiar to metal NPs, and the reaction systems with extremely low loadings of catalysts.

Funding: This research received no external funding.

Data Availability Statement: Not applicable.

Conflicts of Interest: The author declare no conflict of interest.

\section{References}

1. Rampino, L.D.; Nord, F.F. Preparation of palladium and platinum synthetic high polymer catalysts and the relationship between particle size and rate of hydrogenation. J. Am. Chem. Soc. 1941, 63, 2745-2749. [CrossRef]

2. Reetz, M.T.; Lohmer, G. Propylene carbonate stabilized nanostructured palladium clusters as catalysts in Heck reactions. Chem. Commun. 1996, 1921-1922. Available online: https:/ / pubs.rsc.org/en/content/articlelanding/1996/CC/cc9960001921 (accessed on 10 August 2021). [CrossRef]

3. Reetz, M.T.; Breinbauer, R.; Wanninger, K. Suzuki and Heck reactions catalyzed by preformed palladium clusters and palladiumnickel bimetallic clusters. Tetrahedron Lett. 1996, 37, 4499-4502. [CrossRef]

4. Ayogu, J.I.; Onoabedje, E.A. Prospects and applications of palladium nanoparticles in the cross-coupling of (hetero)aryl halides and related analogues. ChemistryOpen 2021, 10, 430-450. [CrossRef] [PubMed] 
5. Aksoy, M.; Kilic, H.; Nişanci, B.; Metin, Ö. Recent advances in the development of palladium nanocatalysts for sustainable organic transformations. Inorg. Chem. Front. 2021, 8, 499-545. [CrossRef]

6. Söğütlü, I.; Mahmood, E.A.; Shendy, S.A.; Ebrahimiasl, S.; Vessally, E. Recent progress in application of nanocatalysts for carbonylative Suzuki cross-coupling reactions. RSC Adv. 2021, 11, 2112-2125. [CrossRef]

7. Bhakta, S.; Ghosh, T. Nickel nanocatalysis: An efficient tool for Heck reaction. ChemCatChem 2021, 13, 828-835. [CrossRef]

8. Wani, I.A.; Jain, S.K.; Khan, H.; Kalam, A.; Ahmad, T. Gold nanoparticles as efficient catalysts in organic transformations. Curr. Pharm. Biotechnol. 2021, 22, 724-732. [CrossRef]

9. Ardakani, L.S.; Surendar, A.; Thangavelu, L.; Mandal, T. Silver nanoparticles (Ag NPs) as catalyst in chemical reactions. Synth. Commun. 2021, 51, 1516-1536.

10. Jinfeng, F.; Yanmei, L.; Yan, H.; Moghadasi, Z. Synthesis of heterocycles catalyzed by metallic nanoparticles (NPs). Synth. Commun. 2021, 51. [CrossRef]

11. Huang, W.; Jiang, J.; Mandal, T. Ferrite nanoparticles: Catalysis in multicomponent reactions (MCR). Synth. Commun. 2021, 51, 2397-2422. [CrossRef]

12. Huang, J.; Lu, D.; Mandal, T. Catalytic application of copper iodide nanoparticles in organic synthesis. Synth. Commun. 2021, 51, 1923-1946.

13. Alsalahi, W.; Trzeciak, A.M. Rhodium-catalyzed hydroformylation under green conditions: Aqueous/organic biphasic, "on water", solventless and Rh nanoparticle based systems. Cood. Chem. Rev. 2021, 430, 213732. [CrossRef]

14. Gholinejad, M.; Khosravi, F.; Afrasi, M.; Sansano, J.M.; Nájera, C. Applications of bimetallic PdCu catalysts. Catal. Sci. Technol. 2021, 11, 2652-2702. [CrossRef]

15. Recent advances in metal-nanoparticle-catalyzed coupling reactions assisted by microwave irradiation. Synthesis 2021, 53, 3513-3521. [CrossRef]

16. Din Reshi, N.U.; Samuelson, A.G. Recent advances in soluble ruthenium(0) nanocatalysts and their reactivity. Appl. Catal. A Gen. 2020, 598, 117561. [CrossRef]

17. Sankar, M.; He, Q.; Engel, R.V.; Sainna, M.A.; Jogsdail, A.J.; Roldan, A.; Willock, D.J.; Agarwal, N.; Kiely, C.J.; Hutchings, G.J. Role of the support in gold-containing nanoparticles as heterogeneous catalysts. Chem. Rev. 2020, 120, 3890-3938. [CrossRef] [PubMed]

18. Ponti, A.; Molteni, G. Nanoparticle-catalyzed 1,3-dipolar cycloadditions. Eur. J. Org. Chem. 2020, 6173-6191. [CrossRef]

19. Dhameliya, T.M.; Donga, H.A.; Vaghela, P.V.; Panchal, B.G.; Sureja, D.K.; Bodiwala, K.B.; Chhabria, M.T. A decennary update on applications of metal nanoparticles (MNPs) in the synthesis of nitrogen- and oxygen-containing heterocyclic scaffolds. RSC Adv. 2020, 10, 32740-32820. [CrossRef]

20. Van Vaerenbergh, B.; Lauwaert, J.; Vermeir, P.; Thybaut, J.W.; De Clercq, J. Towards high-performance heterogeneous palladium nanoparticle catalysts for sustainable liquid-phase reactions. React. Chem. Eng. 2020, 5, 1556-1618. [CrossRef]

21. Van Vaerenbergh, B.; Lauwaert, J.; Vermeir, P.; De Clercq, J.; Thybaut, J.W. Chapter one-Synthesis and support interaction effects on the palladium nanoparticle catalyst characteristics. Adv. Catal. 2019, 65, 1-120.

22. Trzeciak, A.M.; Augustyniak, A.W. The role of palladium nanoparticles in catalytic C-C cross-coupling reactions. Cood. Chem. Rev. 2019, 384, 1-20. [CrossRef]

23. Ohtaka, A. Transition-metal nanoparticles catalyzed carbon-carbon coupling reactions in water. Curr. Org. Chem. 2019, 23, 689-703. [CrossRef]

24. Monfared, A.; Mohammadi, R.; Ahmadi, S.; Nikpassand, M.; Hosseinian, A. Recent advances in the application of nano-catalysts for Hiyama cross-coupling reactions. RSC Adv. 2019, 9, 3185-3202. [CrossRef]

25. Roy, D.; Uozumi, Y. Recent advances in palladium-catalyzed cross-coupling reactions at ppm to ppb molar catalyst loading. Adv. Synth. Catal. 2018, 360, 602-625. [CrossRef]

26. Liu, L.; Corma, A. Metal catalysts for heterogeneous catalysis: From single atoms to nanoclusters and nanoparticles. Chem. Rev. 2018, 118, 4981-5079. [CrossRef]

27. Mpungose, P.P.; Vundla, Z.P.; Maguire, G.E.M.; Friedrich, H.B. The current status of heterogeneous palladium catalysed Heck and Suzuki cross-coupling reactions. Molecules 2018, 23, 1676. [CrossRef]

28. Biffis, A.; Centomo, P.; Del Zotto, A.; Zecca, M. Pd metal catalysts for cross-couplings and related reactions in the 21st century: A critical review. Chem. Rev. 2018, 118, 2249-2295. [CrossRef]

29. Ojha, N.K.; Zyryanov, G.V.; Majee, A.; Charushin, V.N.; Chupakhin, O.N.; Santra, S. Copper nanoparticles as inexpensive and efficient catalyst: A valuable contribution in organic synthesis. Coord. Chem. Rev. 2017, 353, 1-57. [CrossRef]

30. Nasrollahzadeh, M.; Atarod, M.; Alizadeh, M.; Hatamifard, A.; Sajadi, S.M. Recent advances in the application of heterogeneous nanocatalysts for Sonogashira coupling reactions. Curr. Org. Chem. 2017, 21, 708-749. [CrossRef]

31. Díaz-Sánchez, M.; Díaz-García, D.; Prashar, S.; Gómez-Ruiz, S. Palladium nanoparticles supported on silica, alumina or titania: Greener alternatives for Suzuki-Miyaura and other C-C coupling reactions. Environ. Chem. Lett. 2019, 17, 1585-1602. [CrossRef]

32. Veerakumar, P.; Thanasekaran, P.; Lu, K.-L.; Liu, S.-B.; Rajagopal, S. Functionalized silica matrices and palladium: A versatile heterogeneous catalyst for Suzuki, Heck, and Sonogashira reactions. ACS Sustainable Chem. Eng. 2017, 5, 6357-6376. [CrossRef]

33. Del Zotto, A.; Zuccaccia, D. Metallic palladium, PdO, and palladium supported on metal oxides for the Suzuki-Miyaura crosscoupling reaction: A unified view of the process of formation of the catalytically active species in solution. Catal. Sci. Technol. 2017, 7, 3934-3951. [CrossRef] 
34. Utsunomiya, M.; Kondo, R.; Oshima, T.; Safumi, M.; Suzuki, T.; Obora, Y. Cross $\beta$-arylmethylation of alcohols catalyzed by recyclable Ti-Pd alloys not requiring pre-activation. Chem. Commun. 2021, 57, 5139-5142. [CrossRef]

35. Handa, S.; Jin, B.; Bora, P.P.; Wang, Y.; Zhang, X.; Gallou, F.; Reilly, J.; Lipshutz, B.H. Sonogashira coupling catalyzed by Fe nanoparticles containing ppm levels of reusable Pd, under mild aqueous micellar conditions. ACS Catal. 2019, 9, $2423-2431$. [CrossRef]

36. Elazab, H.A.; Radwan, M.A.; El-Idreesy, T.T. Facile microwave-assisted synthetic approach to palladium nanoparticles supported on copper oxide as an efficient catalyst for Heck and Sonogashira cross-coupling reactions. Int. J. Nanosci. 2019, 18, 1850032. [CrossRef]

37. Dong, Z.; Gao, P.; Xiao, Y.; Chen, J.; Wang, W. Pd-Co nanoparticles supported on calcined Mg-Fe hydrotalcites for the SuzukiMiyaura reaction in water with high turnover numbers. Catalysts 2019, 9, 1061. [CrossRef]

38. Yamada, M.; Shio, Y.; Akiyama, T.; Honma, T.; Ohki, Y.; Takahashi, M.; Murai, K.; Arisawa, M. Ligand-free Suzuki-Miyaura coupling reaction of an aryl chloride using a continuous irradiation type microwave and a palladium nanoparticle catalyst: Effect of a co-existing solid. Green Chem. 2019, 21, 4541-4549. [CrossRef]

39. Taniguchi, T.; Saito, N.; Doi, R.; Kimoto, A.; Hoshiya, N.; Fujiki, K.; Shuto, S.; Fujioka, H.; Arisawa, M.; Sato, Y. Nickel nanoparticlecatalyzed carboxylation of unsaturated hydrocarbon with $\mathrm{CO}_{2}$ using sulfur-modified Au-supported nickel material. Chem. Lett. 2019, 48, 1406-1409. [CrossRef]

40. Mahanta, A.; Raul, P.K.; Saikia, S.; Bora, U.; Thakur, A.J. Methanol aided synthesis of PdNPs decorated on montmorillonite K 10 and its implication in Suzuki Miyaura type cross coupling reaction under base free condition. Appl. Organomet. Chem. 2018, 32, e4192. [CrossRef]

41. Elazab, H.A.; Sadek, M.A.; El-Idreesy, T.T. Microwave-assisted synthesis of palladium nanoparticles supported on copper oxide in aqueous medium as an efficient catalyst for Suzuki cross-coupling reaction. Adsorpt. Sci. Technol. 2018, 36, 1352-1365. [CrossRef]

42. Yu, D.; Jie, B.; Wang, J.; Li, C. Design a fabrication of PdO/Ce $\mathrm{e}_{\mathrm{y}}$ composite catalysts with coaxial nanotuber and studies of their synergistic performance in Suzuki-Miyaura reactions. J. Catal. 2018, 365, 195-203. [CrossRef]

43. Miura, H.; Nagao, M.; Hosokawa, S.; Shishido, T.; Inoue, M.; Wada, K. Generation of active ruthenium catalysts for hydroarylation of C-C multiple bonds from isolated $\mathrm{Ru}(\mathrm{IV})=\mathrm{O}$ species supported on $\mathrm{CeO}_{2}$. Bull. Chem. Soc. Jpn 2018, 91, 1397-1401. [CrossRef]

44. Ketike, T.; Velpula, V.R.K.; Madduluri, V.R.; Kamaraju, S.R.R.; Burri, D.R. Carbonylative Suzuki-Miyaura cross-coupling over Pd NPs/Rice-Husk carbon-silica solid catalyst: Effect of 1,4-dioxane solvent. ChemistrySelect 2018, 3, 7164-7169. [CrossRef]

45. Del Zotto, A.; Colussi, S.; Trovarelli, A. Pd/REOs catalysts applied to the Suzuki-Miyaura coupling. A comparison of their catalytic performance and reusability. Inorg. Chim. Acta 2018, 470, 275-283. [CrossRef]

46. Hu, Q.; Liu, X.; Tang, L.; Min, D.; Shi, T.; Zhang, W. Pd-ZnO nanowire arrays as recyclable catalyst for 4-nitrophenol reduction and Suzuki coupling reactions. RSC Adv. 2017, 7, 7964-7972. [CrossRef]

47. Shabbir, S.; Lee, S.; Lim, M.; Lee, H.; Ko, H.; Lee, Y.; Rhee, H. Pd nanoparticles on reverse phase silica gel as recyclable catalyst for Suzuki-Miyaura cross coupling reaction and hydrogenation in water. J. Organomet. Chem. 2017, 846, 296-304. [CrossRef]

48. Raza, F.; Yim, D.; Park, J.H.; Kim, H.-I.; Jeon, S.-J.; Kim, J.-H. Structuring Pd nanoparticles on 2 H-WS $_{2}$ nanosheets induced excellent photocatalytic activity for cross-coupling reactions under visible light. J. Am. Chem. Soc. 2017, 139, 14767-14774. [CrossRef] [PubMed]

49. Hossain, A.M.S.; Balbín, A.; Erami, R.S.; Prashar, S.; Fajardo, M.; Gómez-Ruiz, S. Synthesis and study of the catalytic applications in C-C coupling reactions of hybrid nanosystems based on alumina and palladium nanoparticles. Inorg. Chim. Acta 2017, 455, 645-652. [CrossRef]

50. Pitre, S.P.; Scaiano, J.C.; Yoon, T.P. Photocatalytic indole Diels-Alder cycloadditions mediated by heterogeneous platinum-modified titanium dioxide. ACS Catal. 2017, 7, 6440-6444. [CrossRef] [PubMed]

51. Shin, H.H.; Kang, E.; Park, H.; Han, T.; Lee, C.-H.; Lim, D.-K. Pd-nanodot decorated MoS $_{2}$ nanosheets as a highly efficient photocatalyst for the visible-light-induced Suzuki-Miyaura coupling reaction. J. Mater. Chem. A 2017, 5, 24965-24971. [CrossRef]

52. Hamdi, J.; Blanco, A.A.; Diehl, B.; Wiley, J.B.; Trudell, M.L. Room-temperature aqueous Suzuki-Miyaura cross-coupling reactions catalyzed via a recyclable palladium@halloysite nanocomposite. Org. Lett. 2019, 21, 3471-3475. [CrossRef]

53. Van Vaerenbergh, B.; De Vlieger, K.; Claeys, K.; Vanhoutte, G.; De Clercq, J.; Vermeir, P.; Verberckmoes, A. The effect on the hydrotalcite structure and nanoparticle size on the catalytic performance of supported palladium nanoparticle catalysts in Suzuki cross-coupling. Appl. Catal. A Gen. 2018, 550, 236-244. [CrossRef]

54. Gholinejad, M.; Bahrami, M.; Nájera, C. A fluorescence active catalyst support comprising carbon quantum dots and magnesium oxide doping for stabilization of palladium nanoparticles: Application as a recoverable catalyst for Suzuki reaction in water. Mol. Catal. 2017, 433, 12-19. [CrossRef]

55. Miura, H.; Tanaka, Y.; Nakahara, K.; Shishido, T. Reductive cycloisomerization of diynes by supported palladium catalysts and subsequent [4+2] cycloaddition for one-pot synthesis of cyclohexenes. ChemCatChem 2020, 12, 455-458. [CrossRef]

56. Miura, H.; Tanaka, Y.; Nakahara, K.; Hachiya, Y.; Endo, K.; Shishido, T. Concerted catalysis by adjacent palladium and gold in alloy nanoparticles for the versatile and practical [2+2+2] cycloaddition of alkynes. Angew. Chem. Int. Ed. 2018, 57, 6136-6140. [CrossRef]

57. Miura, H.; Shishido, T. Concerted catalysis of $\mathrm{Pd}$ and $\mathrm{Au}$ on alloy nanoparticles for efficient heterogeneous molecular transformation. Chem. Lett. 2021, 50, 346-352. [CrossRef] 
58. An, J.; Wang, Y.; Zhang, Z.; Zhang, J.; Gocyla, M.; Dunin-Borkowski, R.E.; Wang, F. Linear-regioselective hydromethoxycarbonylation of styrene using Ru-clusters $/ \mathrm{CeO}_{2}$ catalyst. Chin. J. Catal. 2020, 41, 963-969. [CrossRef]

59. An, J.; Wang, Y.; Lu, J.; Zhang, J.; Zhang, Z.; Xu, S.; Liu, X.; Zhang, T.; Gocyla, M.; Heggen, M.; et al. Acid-promoter-free ethylene methoxycarbonylation over Ru-Clusters/ceria: The catalysis of interfacial Lewis acid-base pair. J. Am. Chem. Soc. 2018, 140, 4172-4181. [CrossRef]

60. An, J.; Wang, Y.; Zhang, Z.; Zhao, Z.; Zhang, J.; Wang, F. The synthesis of quinazolinones from olefins, CO and amines over a heterogeneous Ru-clusters/ceria catalyst. Angew. Chem. Int. Ed. 2018, 57, 12308-12312. [CrossRef]

61. Diacon, A.; Rusen, E.; Mocanu, A.; Nistor, L.C. Supported $\mathrm{Cu}^{0}$ nanoparticles catalyst for controlled radical polymerization reaction and block-copolymer synthesis. Sci. Rep. 2017, 7, 10345. [CrossRef]

62. Alexander, M.; Kalaivani, R.A.; Sriraman, V.; Senthilkumar, U. Electro polymerization of $o$-phenylenediamine using palladium nanoparticles coated fabricated $\mathrm{TiO}_{2}$ nanotubes modified glassy carbon electrode. Asian J. Org. Chem. 2019, 31, $2229-2232$. [CrossRef]

63. Koohgard, M.; Hosseini-Sarvari, M. Enhancement of Suzuki-Miyaura coupling reaction by photocatalytic palladium nanoparticles anchored to $\mathrm{TiO}_{2}$ under visible light irradiation. Catal. Commun. 2018, 111, 10-15. [CrossRef]

64. Hosseini-Sarvari, M.; Bazyar, Z. Visible light driven photocatalytic cross-coupling reactions on nano Pd/ZnO photocatalyst at room-temperature. ChemistrySelect 2018, 3, 1898-1907. [CrossRef]

65. Elhage, A.; Lanterna, A.E.; Scaiano, J.C. Light-induced Sonogashira C-C coupling under mild conditions using supported palladium nanoparticles. ACS Sustainable Chem. Eng. 2018, 6, 1717-1722. [CrossRef]

66. Marina, N.; Lanterna, A.E.; Scaiano, J.C. Expanding the color space in the two-color heterogeneous photocatalysis of Ullmann C-C coupling reactions. ACS Catal. 2018, 8, 7593-7597. [CrossRef]

67. Wang, B.; Guo, X.; Jin, G.; Guo, X. Visible-light-enhanced photocatalytic Sonogashira reaction over silicon carbide supported Pd nanoparticles. Catal. Commun. 2017, 98, 81-84. [CrossRef]

68. Tyagi, A.; Yamamoto, A.; Yoshida, H. Photocatalytic Ullmann coupling of aryl halides by a novel blended catalyst consisting of a $\mathrm{TiO}_{2}$ photocatalyst and an $\mathrm{Al}_{2} \mathrm{O}_{3}$ supported Pd-Au bimetallic catalyst. Catal. Sci. Technol. 2018, 8, 6196-6203. [CrossRef]

69. Tyagi, A.; Yamamoto, A.; Yamamoto, M.; Yoshida, T.; Yoshida, H. Direct cross-coupling between alkenes and tetrahydrofuran with platinum-loaded titanium oxide photocatalyst. Catal. Sci. Technol. 2018, 8, 2546-2556. [CrossRef]

70. Tyagi, A.; Yamamoto, A.; Kato, T.; Yoshida, H. Bifunctional property of Pt nanoparticles deposited on $\mathrm{TiO}_{2}$ for the photocatalytic $\mathrm{sp}^{3} \mathrm{C}$-sp ${ }^{3} \mathrm{C}$ cross-coupling reactions between THF and alkanes. Catal. Sci. Technol. 2017, 7, 2616-2623. [CrossRef]

71. Tyagi, A.; Yamamoto, A.; Yoshida, $\mathrm{H}$. Novel blended catalysts consisting of a $\mathrm{TiO}_{2}$ photocatalyst and an $\mathrm{Al}_{2} \mathrm{O}_{3}$ supported $\mathrm{Pd}-\mathrm{Au}$ bimetallic catalyst for direct dehydrogenative cross-coupling between arenes and tetrahydrofuran. RSC Adv. 2018, 8, 24021-24028. [CrossRef]

72. Naniwa, S.; Hishitani, S.; Yamamoto, A.; Yoshida, H. Ligand-to-metal charge transfer of a pyridine surface complex on TiO ${ }_{2}$ for selective dehydrogenative cross-coupling with benzene. Phys. Chem. Chem. Phys. 2021, 23, 11366-11373. [CrossRef] [PubMed]

73. Rohani, S.; Ziarati, A.; Ziarani, G.M.; Badiei, A.; Burgi, T. Engineering of highly active Au/Pd supported on hydrogenated urchin-like yolk@shell $\mathrm{TiO}_{2}$ for visible light photocatalytic Suzuki coupling. Catal. Sci. Technol. 2019, 9, 3820-3827. [CrossRef]

74. Chakraborty, I.N.; Roy, S.; Devatha, G.; Rao, A.; Pillai, P.P. InP/ZnS quantum dots as efficient visible-light photocatalysts for redox and carbon-carbon coupling reactions. Chem. Mater. 2019, 31, 2258-2262. [CrossRef]

75. Li, Y.; Ren, P.; Zhang, D.; Qiao, W.; Wang, D.; Yang, X.; Wen, X.; Rummeli, M.H.; Niemantsverdriet, H.; Lewis, J.P.; et al. Rationally designed metal cocatalyst for selective photosynthesis of bibenzyls via dehalogenative C-C homocoupling. ACS Catal. 2021, 11, 4338-4348. [CrossRef]

76. Sharma, A.S.; Sharma, V.S.; Kaur, H. Graphitic carbon nitride decorated with $\mathrm{Cu}_{2} \mathrm{O}$ nanoparticles for the visible light activated synthesis of ynones, aminoindolizines, and pyrrolo[1,2-a]quinoline. ACS Appl. Nano Mater. 2020, 3, 1191-1202. [CrossRef]

77. Ma, J.; Tan, X.; Zhang, Q.; Wang, Y.; Zhang, J.; Wang, L. Exploring the size effect of Pt nanoparticles on the photocatalytic nonoxidative coupling of methane. ACS Catal. 2021, 11, 3352-3360. [CrossRef]

78. Tyagi, A.; Matsumoto, T.; Yamamoto, A.; Kato, T.; Yoshida, H. Metal cocatalyst directing photocatalytic acetonylation of toluene via dehydrogenative cross-coupling with acetone. Catal. Lett. 2020, 150, 31-38. [CrossRef]

79. Huang, W.; Cheng, Q.; Ma, D. Recent reports on magnetic nanoparticles supported metallic catalysts: Synthesis of heterocycles. Synth. Commun. 2021, 51, 1321-1339. [CrossRef]

80. Kazemi, M. Based on $\mathrm{CuFe}_{2} \mathrm{O}_{4}$ MNPs: Magnetically recoverable nanocatalysts in coupling reactions. Synth. Commun. 2020, 50, 2114-2131. [CrossRef]

81. Kazemi, M. Based on magnetic nanoparticles: Gold reusable nanomagnetic catalysts in organic synthesis. Synth. Commun. 2020, 50, 2079-2094. [CrossRef]

82. Kazemi, $\mathrm{M}$. Based on $\mathrm{MFe}_{2} \mathrm{O}_{4}(\mathrm{M}=\mathrm{Co}, \mathrm{Cu}$, and $\mathrm{Ni})$ : Magnetically recoverable nanocatalysts in synthesis of heterocyclic structural scaffolds. Synth. Commun. 2020, 50, 1899-1935. [CrossRef]

83. Kazemi, M.; Mohammadi, M. Magnetically recoverable catalysts: Catalysis in synthesis of polyhydroquinolines. Appl. Organomet. Chem. 2019, 34, e5400. [CrossRef]

84. Kazemi, M.; Ghobadi, M.; Mirzaie, A. Cobalt ferrite nanoparticles $\left(\mathrm{CoFe}_{2} \mathrm{O}_{4} \mathrm{MNPs}\right)$ as catalyst and support: Magnetically recoverable nanocatalysts in organic synthesis. Nanotechnol. Rev. 2018, 7, 43-68. [CrossRef] 
85. Sydnes, M.O. The use of palladium on magnetic support as catalyst for Suzuki-Miyaura cross-coupling reactions. Catalysts 2017, 7, 35. [CrossRef]

86. Mulahmetovic, E.; Hargaden, G.C. Recent advances in the development of magnetic catalysts for the Suzuki reaction. Rev. J. Chem. 2017, 7, 373-398. [CrossRef]

87. Sobhani, S.; Zarei, H.; Sansano, J.M. A new nanomagnetic Pd-Co bimetallic alloy as catalyst in the Mizoroki-Heck and BuchwaldHartwig amination reactions in aqueous media. Sci. Rep. 2021, 11, 17025. [CrossRef]

88. Veisi, H.; Zohrabi, A.; Kamangar, S.A.; Karmakar, B.; Saremi, S.G.; Varmira, K.; Hamelian, M. Green synthesis of Pd/Fe ${ }_{3} \mathrm{O}_{4}$ nanoparticles using Chamomile extract as highly active and recyclable catalyst for Suzuki coupling reaction. J. Organomet. Chem. 2021, 951, 122005. [CrossRef]

89. Veisi, H.; Joshani, Z.; Karmakar, B.; Tamoradi, T.; Heravi, M.M.; Gholami, J. Ultrasound assisted synthesis of Pd NPs decorated chitosan-starch functionalized $\mathrm{Fe}_{3} \mathrm{O}_{4}$ nanocomposite catalyst towards Suzuki-Miyaura coupling and reduction of 4-nitrophenol. Int. J. Biol. Macromol. 2021, 172, 104-113. [CrossRef]

90. Baloutaki, B.A.; Sayahi, M.H.; Nikpassand, M.; Kefayati, H. Palladium supported terpyridine modified magnetic nanoparticles as an efficient catalyst for carbon-carbon bond formation. J. Organomet. Chem. 2021, 935, 121682. [CrossRef]

91. Nasseri, M.A.; Kazemnejadi, M.; Allahresani, A.; HussainZadeh, M. NiFe $2 \mathrm{O}_{4} @ \mathrm{SiO}_{2} @ \mathrm{ZrO}_{2} / \mathrm{SO}_{4}{ }^{2-} / \mathrm{Cu} / \mathrm{Co}$ nanoparticles: A novel, efficient, magnetically recyclable and bimetallic catalyst for Pd-free Suzuki, Heck and C-N cross-coupling reactions in aqueous media. New J. Chem. 2021, 45, 7741-7757.

92. Aghbash, K.O.; Alamgholiloo, H.; Pesyan, N.N.; Khaksar, S.; Rostamnia, S. Gold nanoparticle stabilized dithiocarbamate functionalized magnetite carbon as promise clean nanocatalyst for $\mathrm{A}^{3}$-coupling organic transformation. Mol. Catal. 2021, 499, 111252. [CrossRef]

93. Dabiri, M.; Nikbakht, R.; Movahed, S.K. Palladium nanoparticle supported on core-shell FeO $@$ @nitrogen-doped carbon cubes and their photocatalytic activities in selective oxidation of alcohols and Ullmann homocoupling in one reaction system. Mater. Chem. Phys. 2021, 258, 123908. [CrossRef]

94. Sharma, A.K.; Joshi, H.; Singh, A.K. Catalysis with magnetically retrievable and recyclable nanoparticles layered with Pd(0) for C-C/C-O coupling in water. RSC Adv. 2020, 10, 6452-6459. [CrossRef]

95. Solyman, S.M.; Darwish, M.S.A.; Yoon, J. Catalytic activity of hybrid iron oxide silver nanoparticles in methyl methacrylate polymerization. Catalysts 2020, 10, 422. [CrossRef]

96. Heydari, F.; Mobinikhaledi, A.; Zolfigol, M.A. Synthesis of a novel Pd supported polymeric magnetic nanoparticles with ureapyridine bridge: Application as an efficient catalyst for the C-C and C-N bond formation. J. Porous Mater. 2020, $27,395-411$. [CrossRef]

97. Jahanshahi, R.; Khazaee, A.; Sobhani, S.; Sansano, J.M. g- $\mathrm{C}_{3} \mathrm{~N}_{4} / \gamma-\mathrm{Fe}_{2} \mathrm{O}_{3} / \mathrm{TiO}_{2} / \mathrm{Pd}$ : A new magnetically separable photocatalyst for visible-light-driven fluoride-free Hiyama and Suzuki-Miyaura cross-coupling reactions at room temperature. New J. Chem. 2020, 44, 11513-11526. [CrossRef]

98. Veisi, H.; Ozturk, T.; Karmakar, B.; Tamoradi, T.; Hemmati, S. In situ decorated Pd NPs on chitosan-encapsulated $\mathrm{Fe}_{3} \mathrm{O}_{4} / \mathrm{SiO}_{2}-\mathrm{NH}_{2}$ as magnetic catalyst in Suzuki-Miyaura coupling and 4-nitrophenol reduction. Carbohyd. Polym. 2020, 235, 115966. [CrossRef] [PubMed]

99. Gholami, A.; Mokhtary, M.; Nikpassand, M. Glycolic acid-supported cobalt ferrite-catalyzed one-pot synthesis of pyrimido[4,5$b$ ]quinoline and indenopyrido[2,3-d]pyrimidine derivative. Appl. Organomet. Chem. 2020, e6007. [CrossRef]

100. Kaldareh, M.F.; Mokhtary, M.; Nikpassand, M. Nicotinic acid-supported cobalt ferrite-catalyzed one-pot synthesis of substituted chromeno[3,4-b]quinolines. Appl. Organomet. Chem. 2020, 34, e5469. Available online: https://onlinelibrary.wiley.com/doi/abs/ 10.1002/aoc.5469 (accessed on 10 August 2021).

101. Nikpassand, M.; Hsseinnezhad, E. Green synthesis of 4,6-bisarylpyrimidin-2(1H)-ones and azo-linked 4-arylpyrimidin-2(1H)-ones using $\mathrm{NiFe}_{2} \mathrm{O}_{4} @ \mathrm{SiO}_{2}{ }^{n} \mathrm{Pr} @$ glucose amine as a mild nano catalyst. Arab. J. Chem. 2020, 13, 8995-9004. [CrossRef]

102. Nikpassand, M.; Kasmaei, S.A. Tannic acid-functionalized silica coated $\mathrm{Fe}_{3} \mathrm{O}_{4}$ nanoparticles as a novel and magnetically separable catalyst for green synthesis of aryl naptho[1,3]oxazine-2-thiones. J. Inorg. Organomet. P. 2020, 30, 4926.

103. Aghazadeh, B.; Nikpassand, M. "2-Amino glucose" as a substrate for synthesis of magnetically recoverable nanocatalyst $\mathrm{NiFe}_{3} \mathrm{O}_{4} @ \mathrm{SiO}_{2} @$ amino glucose for the green synthesis of novel bis(1,2-dihydro-4-hydroxy-2-oxoquinolin-3-yl)methanes. Carbohyd. Res. 2019, 483, 107755. [CrossRef]

104. Elazab, H.A.; Gadalla, M.A.; Sadek, M.A.; El-Idreesy, T.T. Hydrothermal synthesis of graphene supported Pd/Fe $\mathrm{O}_{4}$ nanoparticles as efficient magnetic catalysts for Suzuki cross-coupling. Biointerface Res. Appl. Chem. 2019, 9, 3906-3911.

105. De Cattelle, A.; Billen, A.; O’Rourke, G.; Brullot, W.; Verbiest, T.; Koeckelberghs, G. Ligand-free, recyclable palladiumfunctionalized magnetite nanoparticles as a catalyst in the Suzuki-, Sonogashira, and Stille reaction. J. Organomet. Chem. 2019, 904, 121005. [CrossRef]

106. Tamoradi, T.; Veisi, H.; Karmakar, B. Pd nanoparticle fabricated tetrahydroharman-3-carboxylic acid analog immobilized $\mathrm{CoFe}_{2} \mathrm{O}_{4}$ catalyzed fast and expedient C-C cross and C-S coupling. ChemistrySelect 2019, 4, 10953-10959. [CrossRef]

107. Veisi, H.; Mohammadi, L.; Hemmati, S.; Tamoradi, T.; Mohammadi, P. In situ immobilized silver nanoparticles on Rubia tinctorum extract-coated ultrasmall iron oxide nanoparticles: An efficient nanocatalyst with magnetic recyclability for synthesis of propargylamines by A ${ }^{3}$ coupling reaction. ACS Omega 2019, 4, 13991-14003. [CrossRef] 
108. Veisi, H.; Hemmati, S.; Safarimehr, P. In situ immobilized palladium nanoparticles on surface of poly-methyldopa coated-magnetic nanoparticles $\left(\mathrm{Fe}_{3} \mathrm{O}_{4} @ \mathrm{PMDA} / \mathrm{Pd}\right)$ : A magnetically recyclable nanocatalyst for cyanation of aryl halides with $\mathrm{K}_{4}\left[\mathrm{Fe}(\mathrm{CN})_{6}\right]$. $J$. Catal. 2018, 365, 204-212. [CrossRef]

109. Veisi, H.; Pirhayati, M.; Kakanejadifard, A.; Mohammadi, P.; Abdi, M.R.; Gholami, J.; Hemmati, S. In situ green synthesis of Pd nanoparticles on tannic acid-modified magnetite nanoparticles as a green reductant and stabilizer agent: Its application as a recyclable nanocatalyst $\left(\mathrm{Fe}_{3} \mathrm{O}_{4} @ \mathrm{TA} / \mathrm{Pd}\right)$ for reduction of 4-nitrophenol and Suzuki reactions. ChemistrySelect 2018, 3, 1820-1826. [CrossRef]

110. Tanhaei, M.; Mahjoub, A.; Nejat, R. Three-dimensional graphene-magnetic palladium nanohybrid: A highly efficient and reusable catalyst for promoting organic reactions. Catal. Lett. 2018, 148, 1549-1561. [CrossRef]

111. Li, J.; Wang, Y.; Jiang, S.; Zhang, H. Facile synthesis of magnetic recyclable palladium-gold alloy nanoclusters catalysts $\mathrm{PdAu}_{\mathrm{r}} / \mathrm{Fe}_{3} \mathrm{O}_{4} @ \mathrm{LDH}$ and its catalytic applications in Heck reaction. J. Organomet. Chem. 2018, 878, 84-95. [CrossRef]

112. Dadras, A.; Naimi-Jamal, M.R.; Moghaddam, F.M.; Ayati, S.E. Suzuki-Miyaura coupling reaction in water in the presence of robust palladium immobilized on modified magnetic $\mathrm{Fe}_{3} \mathrm{O}_{4}$ nanoparticles as a recoverable catalyst. Appl. Organomet. Chem. 2018, 32, e3993. [CrossRef]

113. Veisi, H.; Pirhayati, M.; Kakanejadifard, A. Immobilization of palladium nanoparticles on ionic liquid-triethylammonium chloride functionalized magnetic nanoparticles: As a magnetically separable, stable and recyclable catalyst for Suzuki-Miyaura cross-coupling reactions. Tetrahedron Lett. 2017, 58, 4269-4276. [CrossRef]

114. Rostamizadeh, S.; Estiri, H.; Azad, M. Ullmann homocoupling of aryl iodides catalyzed by gold nanoparticles stabilized on magnetic mesoporous silica. J. Iran. Chem. Soc. 2017, 14, 1005-1010. [CrossRef]

115. Sarvi, I.; Gholizadeh, M.; Izadyar, M. Highly dispersed palladium nanoparticle-loaded magnetic catalyst (FeS@Ep-AG-Pd) for Suzuki reaction in water. Catal. Lett. 2017, 147, 1162-1171. [CrossRef]

116. Khazaei, A.; Khazaei, M.; Nasrollahzadeh, M. Nano- $\mathrm{Fe}_{3} \mathrm{O}_{4} @ \mathrm{SiO}_{2}$ supported $\mathrm{Pd}(0)$ as a magnetically recoverable nanocatalyst for Suzuki coupling reaction in the presence of waste eggshell as low-cost natural base. Tetrahedron 2017, 73, 5624-5633. [CrossRef]

117. Rezaei, S.J.T.; Shamseddin, A.; Ramazani, A.; Malekzadeh, A.M.; Asiabi, P.A. Palladium nanoparticles immobilized on amphiphilic and hyperbranched polymer-functionalized magnetic nanoparticles: An efficient semi-heterogeneous catalyst for Heck reaction. Appl. Organomet. Chem. 2017, 31, e3707. [CrossRef]

118. Hajipour, A.R.; Rezaei, F.; Khohrsandi, Z. Pd/Cu-free Heck and Sonogashira cross-coupling reaction by Co nanoparticles immobilized on magnetic chitosan as reusable catalyst. Green Chem. 2017, 19, 1353-1361. [CrossRef]

119. Nasseri, M.A.; Rezazadeh, Z.; Kazemnejadi, M.; Allahresani, A. A Co-Cu bimetallic magnetic nanocatalyst with synergistic and bifunctional performance for the base-free Suzuki, Sonogashira, and C-N cross-coupling reactions in water. Dalton Trans. 2020, 49, 10645-10660. [CrossRef]

120. Nasseri, M.A.; Rezazadeh, Z.; Kazemnejadi, M.; Allahresani, A. Magnetic Cu-Schiff base complex with an ionic tail as a recyclable bifunctional catalyst for base/Pd-free Sonogashira coupling reaction. J. Iran. Chem. Soc. 2019, 16, 2693-2705. [CrossRef]

121. Hajipour, A.R.; Tavangar-Rizi, Z. Palladium nanoparticles immobilized on magnetic methionine-functionalized chitosan: A versatile catalyst for Suzuki and copper-free Sonogashira reactions of aryl halides at room temperature in water as only solvent. Appl. Organomet. Chem. 2017, 31, e3701. [CrossRef]

122. Lamei, K.; Eshghi, H.; Bakavoli, M.; Rostamnia, S. Highly dispersed copper/ppm palladium nanoparticles as novel magnetically recoverable catalyst for Suzuki reaction under aqueous conditions at room temperature. Appl. Organomet. Chem. 2017, 31 , e3743. [CrossRef]

123. Wang, L.L.; Zhu, L.P.; Bing, N.C.; Wang, L.J. Facile green synthesis of Pd/N-doped carbon nanotubes catalysts and their application in Heck reaction and oxidation of benzyl alcohol. J. Phys. Chem. Solids 2017, 107, 125-130. [CrossRef]

124. Movahed, S.K.; Dabiri, M.; Bazgir, A. Palladium nanoparticle decorated high nitrogen-doped graphene with high catalytic activity for Suzuki-Miyaura and Ullmann-type coupling reactions in aqueous media. Appl. Catal. A. Gen. 2014, 488, 265-274. [CrossRef]

125. Zheng, K.; Shen, C.; Qiao, J.; Tong, J.; Jin, J.; Zhang, P. Novel magnetically-recyclable, nitrogen-doped Fe $\mathrm{O}_{4} @ P d \mathrm{NPs}_{\text {for }}$ Suzuki-Miyaura coupling and their application in the synthesis of Crizotinib. Catalysts 2018, 8, 443. [CrossRef]

126. Hajipour, A.R.; Abolfathi, P. Nickel embedded on triazole-modified magnetic nanoparticles: A novel and sustainable heterogeneous catalyst for Hiyama reaction in fluoride-free condition. Catal. Commun. 2018, 103, 92-95. [CrossRef]

127. Moghadam, H.H.; Sobhani, S.; Sansano, J.M. New nanomagnetic heterogeneous cobalt catalyst for the synthesis of aryl nitriles and biaryls. ACS Omega 2020, 5, 18619-18627. [CrossRef] [PubMed]

128. Cattelle, A.D.; Billen, A.; Brullot, W.; Verbiest, T.; Koeckelberghs, G. Synthesis of poly(phenylene ethynylene) using an easily recyclable Pd-functionalized magnetite nanoparticle catalyst. Macromolecules 2020, 53, 1998-2005. [CrossRef]

129. Yazdani, H.; Pardis, S.; Loni, M.; Bazgir, A. Gold nanoparticles as a Lewis acid catalyst in 1,3-dipolar cycloaddition reaction. Catal. Commun. 2020, 134, 105844. [CrossRef]

130. Kaur, H.; Kumar, M.; Bhalla, V. Photocatalytic ensemble HP-T@Au-Fe $\mathrm{O}_{4}$ : Synergistic and balanced operation in Kumada and Heck coupling reactions. Green Chem. 2020, 22, 8036-8045. [CrossRef]

131. Kaur, H.; Kaur, M.; Walia, P.K.; Kumar, M.; Bhalla, V. Encapsulating $\mathrm{Au}-\mathrm{Fe}_{3} \mathrm{O}_{4}$ nanodots into AIE active supramolecular assemblies: Ambient visible light harvesting "Dip-Strip" photocatalyst for C-C/C-N bond formation reactions. Chem. Asian J. 2019, 14, 809-813. [CrossRef] 
132. Kaur, H.; Pramanik, S.; Kumar, M.; Bhalla, V. Polythiophene-encapsulated bimetallic $\mathrm{Au}-\mathrm{Fe}_{3} \mathrm{O}_{4}$ nano-hybrid materials: A potential tandem photocatalytic system for nondirected $\mathrm{C}\left(\mathrm{sp}^{2}\right)$-H activation for the synthesis of quinoline carboxylates. ACS Catal. 2017, 7, 2007-2021. [CrossRef]

133. Azadi, G.; Kazemi, F.; Firouzeh, E. Visible-light-driven photocatalytic Suzuki-Miyaura coupling reaction using novel retrievable magnetic photocatalyst. ChemistrySelect 2021, 6, 630-639. [CrossRef]

134. Churipard, S.R.; Kanakikodi, K.S.; Maradur, S.P. Metal nanoparticles supported on mesoporous polymers: Realizing the synergetic effect to achieve superior catalytic performance. In Advanced Heterogeneous Catalysts Volume 1: Applications at the Nano-Scale; Chapter 16; American Chemical Society: Washington, DC, USA, 2020; pp. 483-511. Available online: https: //pubs.acs.org/doi/abs/10.1021/bk-2020-1359.ch016 (accessed on 10 August 2021).

135. Tao, R.; Ma, X.; Wei, X.; Jin, Y.; Qiu, L.; Zhang, W. Porous organic polymer material supported palladium nanoparticles. J. Mater. Chem. A 2020, 8, 17360-17391. [CrossRef]

136. Hong, K.; Sajjadi, M.; Suh, J.M.; Zhang, K.; Nasrollahzadeh, M.; Jang, H.W.; Varma, R.S.; Shokouhimehr, M. Palladium nanoparticles on assorted nanostructured supports: Applications for Suzuki, Heck, and Sonogashira cross-coupling reactions. ACS Appl. Nano Mater. 2020, 3, 2070-2103. [CrossRef]

137. Dabiri, M.; Fazli, H.; Salarinejad, N.; Movahed, S.K. Pd nanoparticles supported on cubic shaped ZIF-based materials and their catalytic activities in organic reactions. Mater. Res. Bull. 2021, 133, 111015. [CrossRef]

138. Cho, H.J.; Kim, D.; Xu, B. Selective control in tandem catalytic furfural upgrading on zeolite-encapsulated Pt nanoparticles through site and solvent engineering. ACS Catal. 2020, 10, 4770-4779. [CrossRef]

139. Cho, H.J.; Kim, D.; Li, S.; Su, D.; Ma, D.; Xu, B. Molecular-level proximity of metal and acid sites in zeolite-encapsulated Pt nanoparticles for selective multistep tandem catalysis. ACS Catal. 2020, 10, 3340-3348. [CrossRef]

140. Hajipour, A.R.; Khorsandi, Z. Pd/Cu-free Heck and Sonogashira coupling reactions applying cobalt nanoparticles supported on multifunctional porous organic hybrid. Appl. Organomet. Chem. 2020, 34, e5398. [CrossRef]

141. Kalay, E.; Cetin, S.; Kolemen, S.; Metin, Ö. A facile synthesis of mesoporous graphitic carbon nitride supported palladium nanoparticles as highly effective and reusable catalysts for the Stille coupling reactions under mild conditions. New J. Chem. 2020, 44, 6714-6723. [CrossRef]

142. Dastjerdi, F.H.; Ghorbani-Vaghei, R.; Alavinia, S. Copper iodide nanoparticles immobilized porous polysulfonamide: An effective nanocatalyst for synthesis of imidazo[1,2-a]pyridines. Catal. Lett. 2020, 150, 3514-3522. [CrossRef]

143. Guo, B.; Li, H.-X.; Zha, C.-H.; Young, D.J.; Li, H.-Y.; Lang, J.-P. Visible-light-enhanced Suzuki-Miyaura reactions of aryl chlorides in water with Pd NPs supported on a conjugated nanoporous polycarbazole. ChemSusChem 2019, 12, 1421-1427. [CrossRef] [PubMed]

144. Ju, P.; Wu, S.; Su, Q.; Li, X.; Liu, Z.; Li, G.; Wu, Q. Salen-porphyrin-based conjugated microporous polymer supported Pd nanoparticles: Highly efficient heterogeneous catalysts for aqueous C-C coupling reactions. J. Mater. Chem. A 2019, 7, 2660-2666. [CrossRef]

145. Cho, H.J.; Kim, D.; Li, J.; Su, D.; Xu, B. Zeolite-encapsulated Pt nanoparticles for tandem catalysis. J. Am. Chem. Soc. 2018, 140, 13514-13520. [CrossRef] [PubMed]

146. Liu, M.; Wu, L.; Han, J.; Xu, X.; He, C.; Wang, P.; Wei, Q.; Yang, W. Facile synthesis of palladium nanoparticles on hierarchical hollow silica spheres and its catalytic properties in Suzuki-reaction. Roy. Soc. Open Sci. 2018, 5, 180545. [CrossRef] [PubMed]

147. Zhu, W.; Wang, X.; Li, T.; Shen, R.; Hao, S.-J.; Li, Y.; Wang, Q.; Li, Z.; Gu, Z.-G. Porphyrin-based porous polyimide polymer/Pd nanoparticle composites as efficient catalysts for Suzuki-Miyaura coupling reactions. Polym. Chem. 2018, 9, 1430-1438. [CrossRef]

148. Mondal, P.; Khatun, R.; Bhanja, P.; Bhaumik, A.; Das, D.; Islam, S.M. Palladium nanoparticles embedded on mesoporous TiO 2 material $\left(\mathrm{Pd} @ \mathrm{MTiO}_{2}\right)$ as an efficient heterogeneous catalyst for Suzuki-coupling reactions in water medium. J. Colloid Interf. Sci. 2017, 508, 378-386. [CrossRef]

149. Zhou, H.; Wu, C.; Wu, Q.; Guo, B.; Liu, W.; Li, G.; Su, Q.; Mu, Y. Palladium nanoparticles supported on carbazole functionalized mesoporous organic polymer: Synthesis and their application as efficient catalysts for Suzuki-Miyaura cross coupling reaction. Polym. Chem. 2017, 8, 1488-1494. [CrossRef]

150. Wang, K.; Yang, L.; Zhao, W.; Cao, L.; Sun, Z.; Zhang, F. A facile synthesis of copper nanoparticles supported on ordered mesoporous polymer as an efficient and stable catalyst for solvent-free Sonogashira coupling reactions. Green Chem. 2017, 19, 1949-1957. [CrossRef]

151. Puthiaraj, P.; Ahn, W.-S. Ullmann coupling of aryl chlorides in water catalyzed by palladium nanoparticles supported on amine-grafted porous aromatic polymer. Mol. Catal. 2017, 437, 73-79. [CrossRef]

152. Ke, W.; Cui, T.; Yu, Q.; Wang, M.; Lv, L.; Wang, H.; Jiang, Z.; Li, X. Mesoporous H-ZSM-5 nanocrystals with programmable number of acid sites as "solid ligands" to activate Pd nanoparticles for C-C coupling reactions. Nano Res. 2018, 11, 874-881. [CrossRef]

153. Lu, S.; Hu, Y.; Wan, S.; McCaffrey, R.; Jin, Y.; Gu, H.; Zhang, W. Synthesis of ultrafine and highly dispersed metal nanoparticles confined in a thioether-containing covalent organic framework and their catalytic applications. J. Am. Chem. Soc. 2017, 139, 17082-17088. [CrossRef]

154. Akiyama, T.; Wada, Y.; Yamada, M.; Shio, Y.; Honma, T.; Shimoda, S.; Tsuruta, K.; Tamenori, Y.; Haneoka, H.; Suzuki, T.; et al. Self-assembled multilayer iron(0) nanoparticles catalyst for ligand-free carbon-carbon/carbon-nitrogen bond-forming reactions. Org. Lett. 2020, 22, 7244-7249. [CrossRef] [PubMed] 
155. Akiyama, T.; Wada, Y.; Jenkinson, K.; Honma, T.; Tsuruta, K.; Tamenori, Y.; Haneoka, H.; Takehara, T.; Suzuki, T.; Murai, K.; et al. Reusable immobilized iron(II) nanoparticle precatalysts for ligand-free Kumada coupling. ACS Appl. Nano Mater. 2018, 1, 6950-6958. [CrossRef]

156. Akiyama, T.; Taniguchi, T.; Saito, N.; Doi, R.; Honma, T.; Tamenori, Y.; Ohki, Y.; Takahashi, N.; Fujioka, H.; Sato, Y.; et al. Ligand-free Suzuki-Miyaura coupling using ruthenium(0) nanoparticles and a continuously irradiating microwave system. Green Chem. 2017, 19, 3357-3369. [CrossRef]

157. Hoshiya, N.; Fujiki, K.; Taniguchi, T.; Honma, T.; Tamenori, Y.; Xiao, M.; Saito, N.; Yokoyama, M.; Ishii, A.; Fujioka, H.; et al. Selfassembled multilayer-stabilized nickel nanoparticle catalyst for ligand-free cross-coupling reactions: In situ metal nanoparticle and nanospace simultaneous organization. Adv. Synth. Catal. 2016, 358, 2449-2459. [CrossRef]

158. Arisawa, M.; Al-Amin, M.; Honma, T.; Tamenori, Y.; Arai, S.; Hoshiya, N.; Sato, T.; Yokoyama, M.; Ishii, A.; Takeguchi, M.; et al. Formation of self-assembled multilayer stable palladium nanoparticles for ligand-free coupling reactions. RSC Adv. 2015, 5, 676-683. [CrossRef]

159. Norouzi, N.; Das, M.K.; Richard, A.J.; Ibrahim, A.A.; El-Kaderi, H.M.; El-Shall, M.S. Heterogeneous catalysis by ultra-small bimetallic nanoparticles surpassing homogeneous catalysis for caron-carbon bond forming reactions. Nanoscale 2020, 12, 1919119202. [CrossRef] [PubMed]

160. Jang, W.; Yun, J.; Ludwig, L.; Jang, S.G.; Bae, J.Y.; Byun, H.; Kim, J.-H. Comparative catalytic properties of supported and encapsulated gold nanoparticles in homocoupling reactions. Front. Chem. 2020, 8, 834. [CrossRef] [PubMed]

161. Dewan, A.; Sarmah, M.; Bharali, P.; Thakur, A.J.; Boruah, P.K.; Das, M.R.; Bora, U. Pd nanoparticles-loaded honeycomb-structured bio-nanocellulose as a heterogeneous catalyst for heteroaryl cross-coupling reaction. ACS Sustain. Chem. Eng. 2021, 9, 954-966. [CrossRef]

162. Zhuang, Q.; Gao, R.; Shi, M.; Lin, X.; Xie, A.; Dong, W. Confining palladium nanoparticles in microporous tetrastyrene polymer enables efficient size-selective heterogeneous catalysis. ACS Appl. Nano Mater. 2021, 4, 3869-3876. [CrossRef]

163. Cho, H.J.; Kim, D.; Xu, B. Pore size engineering enabled selectivity control in tandem catalytic upgrading of cyclopentanone on zeolite-encapsulated Pt nanoparticles. ACS Catal. 2020, 10, 8850-8859. [CrossRef]

164. Sun, P.; Lin, S.; Guo, H.; Su, J.; Shi, L. A highly dispersed copper nanoparticles catalyst with a large number of weak acid centers for efficiently synthesizing the high value-added 3-methylindole by aniline and biomass-derived glycerin. Catal. Lett. 2021, 151, 463-477. [CrossRef]

165. Díaz-Sánchez, M.; Gómez, J.; Prashar, S.; Horáček, M.; Lamač, M.; Urbán, B.; Pinkas, J.; Gómez-Ruiz, S. Multifunctional catalysts based on palladium nanoparticles supported on functionalized halloysites: Application in catalytic C-C coupling, selective oxidation and dehalogenation reactions. Appl. Clay Sci. 2021, 214, 106272. [CrossRef]

166. Luo, S.; Zeng, Z.; Zeng, G.; Liu, Z.; Xiao, R.; Chen, M.; Tang, L.; Tang, W.; Lai, C.; Cheng, M.; et al. Metal organic frameworks as robust host of palladium nanoparticles in heterogeneous catalysis: Synthesis, application, and prospect. ACS Appl. Mater. Interfaces 2019, 11, 32579-32598. [CrossRef]

167. Xiang, W.; Zhang, Y.; Lin, H.; Liu, C.-J. Nanoparticle/metal-organic framework composites for catalytic applications: Current status and perspective. Molecules 2017, 22, 2103. [CrossRef]

168. Ferlin, F.; Sciosci, D.; Valentini, F.; Menzio, J.; Cravotto, G.; Martina, K.; Vaccaro, L. si-Gly-CD-PdNPs as a hybrid heterogeneous catalyst for environmentally friendly continuous flow Sonogashira cross-coupling. Green Chem. 2021, 23, 7210-7218. [CrossRef]

169. Gorji, S.; Ghorbani-Vaghei, R. Ag nanoparticles stabilized on basalt fibers as a novel, stable, and reusable catalyst for SuzukiMiyaura coupling reactions. Appl. Organomet. Chem. 2021, 35, e6018. [CrossRef]

170. Alamgholiloo, H.; Pesyan, N.N.; Rostamnia, S. A novel strategy for stabilization of sub-nanometric Pd colloids on kryptofix functionalized MCM-41: Nanoengineered material for Stille coupling transformation. Sci. Rep. 2021, 11, 18417. [CrossRef]

171. Li, J.; Song, Y.; Wang, Y.; Zhang, H. Ultrafine PdCu nanoclusters by ultrasonic-assisted reduction on the LDHs/rGO hybrid with significantly enhanced Heck reactivity. ACS Appl. Mater. Interfaces 2020, 12, 50365-50376. [CrossRef]

172. Anastasiou, I.; Van Velthoven, N.; Tomarelli, E.; Lombi, A.; Lanari, D.; Liu, P.; Bals, S.; De Vos, D.E.; Vaccaro, L. C2-H Arylation of Indoles Catalyzed by Palladium-Containing Metal-Organic-Framework in $\gamma$-Valerolactone. ChemSusChem 2020, 13, $2786-2791$. [CrossRef]

173. Rohani, S.; Ziarani, G.M.; Ziarati, A.; Badiei, A. Designer 3D CoAl-layered double hydroxide@N,S doped graphene hollow architecture decorated with Pd nanoparticles for Sonogashira couplings. Appl. Surf. Sci. 2019, 496, 143599. [CrossRef]

174. Tamoradi, T.; Ghadermazi, M.; Ghorbani-Choghamarani, A. SBA-15@adenine-Pd: A novel and green heterogeneous nanocatalyst in Suzuki and Stille reactions and synthesis of sulfides. J. Porous Mater. 2019, 26, 121-131. [CrossRef]

175. Elazab, H.A.; El-Idreesy, T. T Polyvinylpyrrolidone-reduced graphene oxide-Pd nanoparticles as an efficient nanocomposite for catalysis applications in cross-coupling reactions. Bull. Chem. React. Eng. Catal. 2019, 14, 490-501. [CrossRef]

176. Hajipour, A.R.; Khorsandi, Z.; Abeshtian, Z. Pd/Cu-free Heck and Sonogashira reactions using cobalt immobilized on in situ magnetic cross-linked chitosan fibers: A highly efficient and reusable catalyst. Inorg. Chem. Commun. 2019, 107, 107470. [CrossRef]

177. Hemmati, S.; Mehrazin, L.; Pirhayati, M.; Veisi, H. Immobilization of palladium nanoparticles on Metformin-functionalized graphene oxides as a heterogeneous and recyclable nanocatalyst for Suzuki coupling reactions and reduction of 4-nitrophenol. Polyhedron 2019, 158, 414-422. [CrossRef]

178. Veisi, H.; Nikseresht, A.; Ahmadi, N.; Khosravi, K.; Saeidifar, F. Suzuki-Miyaura reaction by heterogeneously supported Pd nanoparticles on thio-modified multi walled carbon nanotubes as efficient nanocatalyst. Polyhedron 2019, 162, 240-244. [CrossRef] 
179. Veisi, H.; Kamangar, S.A.; Mohammadi, P.; Hemmati, S. Palladium nanoparticles-decorated triethanolammonium chloride ionic liquid-modified $\mathrm{TiO}_{2}$ nanoparticles $\left(\mathrm{TiO}_{2} / \mathrm{IL}-\mathrm{Pd}\right)$ : A highly active and recoverable catalyst for Suzuki-Miyaura cross-coupling reaction in aqueous medium. Appl. Organomet. Chem. 2019, 33, e4909. [CrossRef]

180. Li, X.; Zhang, B.; Van Zeeland, R.; Tang, L.; Pei, Y.; Qi, Z.; Goh, T.W.; Stanley, L.M.; Huang, W. Unveiling the effects of linker substitution in Suzuki coupling with palladium nanoparticles in metal-organic frameworks. Catal. Lett. 2018, 148, 940-945. [CrossRef]

181. Dabiri, M.; Alavioon, S.I.; Movahed, S.K. Palladium supported on mesoporous silica/graphene nanohybrid as a highly efficient and reusable heterogeneous catalyst for C-H functionalization. ChemistrySelect 2018, 3, 3487-3494. [CrossRef]

182. Amini, M.M.; Mohammadkhani, A.; Bazgir, A. Dicarboxylic acid-functionalized MCM-41 with embedded palladium nanoparticles as an efficient heterogeneous catalyst for C-C coupling reactions. ChemistrySelect 2018, 3, 1439-1444. [CrossRef]

183. Azaroon, M.; Kiasat, A.R. An efficient and new protocol for the Heck reaction using palladium nanoparticle-engineered dibenzo18-crown-6-ether/MCM-41 nanocomposite in water. Appl. Organomet. Chem. 2018, 32, e4271. [CrossRef]

184. Ghasemi, S.; Karim, S. Mizoroki-Heck cross-coupling reaction of haloarenes mediated by a well-controlled modified polyacrylamide brush grafted silica/Pd nanoparticle system. Bull. Chem. Soc. Jpn. 2017, 90, 485-490. [CrossRef]

185. Veisi, H.; Azadbakht, R.; Saeidifar, F.; Abdi, M.R. Schiff base-functionalized multi walled carbon nano tubes to immobilization of palladium nanoparticles as heterogeneous and recyclable nanocatalyst for Suzuki reaction in aqueous media under mild conditions. Catal. Lett. 2017, 147, 976-986. [CrossRef]

186. Veisi, H.; Mirzaee, N. Ligand-free Mizoroki-Heck reaction using reusable modified graphene oxide-supported Pd(0) nanoparticles. Appl. Organomet. Chem. 2017, 31, e4067.

187. Nikoorazm, M.; Ghorbani-Choghamarani, A.; Ghobadi, M.; Massahi, S. Pd-SBT@MCM-41: As an efficient, stable and recyclable organometallic catalyst for C-C coupling reactions and synthesis of 5-substituted tetrazoles. Appl. Organomet. Chem. 2017, 31, e3848. [CrossRef]

188. de Borros, S.D.; Duarte, J.P.P.; Rocha, L.D.S.; Ramos, V.S.; Navarro, M.I.R.; Archanjo, B.S.; Medeiros, M.E.; De Campos, J.B.; De Costa, M.E.H.M.; Lachter, E.R.; et al. Cyclodextrin-stabilized palladium nanoparticles on ceria: Investigation of support interactions and pivotal promotion in the Suzuki-Miyaura reaction. ChemistrySelect 2020, 5, 7227-7235. [CrossRef]

189. Doustkhah, E.; Rostamnia, S.; Imura, M.; Ide, Y.; Mohammadi, S.; Hyland, C.J.T.; You, J.; Tsunoji, N.; Zeynizadeh, B.; Yamauchi, Y. Thiourea bridged periodic mesoporous organosilica with ultra-small Pd nanoparticles for coupling reactions. RSC Adv. 2017, 7, 56306-56310. [CrossRef]

190. Mohan, A.; Rout, L.; Thomas, A.M.; Peter, J.; Nagappan, S.; Parambadath, S.; Ha, C.-S. Palladium nanoparticles-anchored dualresponsive SBA-15-PNIPAM/PMAA nanoreactor: A novel heterogeneous catalyst for a green Suzuki-Miyaura cross-coupling reaction. RSC Adv. 2020, 10, 28193-28204. [CrossRef]

191. Ghorbani-Vaghei, R.; Sarmast, N.; Rahmatpour, F. Immobilization of palladium nanoparticles as a recyclable heterogeneous catalyst for the Suzuki-Miyaura coupling reaction. Comptes Rendus Chim. 2018, 21, 644-651. [CrossRef]

192. Patel, A.; Patel, A. Stabilized palladium nanoparticles: Synthesis, multi-spectroscopic characterization and application for Suzuki-Miyaura reaction. Catal. Lett. 2018, 148, 3534-3547. [CrossRef]

193. Veisi, H.; Mirzaei, A.; Mohammadi, P. Palladium nanoparticles decorated into a biguanidine modified-KIT-5 mesoporous structure: A recoverable nanocatalyst for ultrasound-assisted Suzuki-Miyaura cross-coupling. RSC Adv. 2019, 9, 41581-51890. [CrossRef]

194. Kozell, V.; Giannoni, T.; Nocchetti, M.; Vivani, R.; Piermatti, O.; Vaccaro, L. Immobilized palladium nanoparticles on zirconium carboxy-aminophosphonates nanosheets as an efficient recoverable heterogeneous catalyst for Suzuki-Miyaura and Heck coupling. Catalysts 2017, 7, 186. [CrossRef]

195. Massaro, M.; Colletti, C.G.; Buscemi, G.; Cataldo, S.; Guernelli, S.; Lazzara, G.; Liotta, L.F.; Parisi, F.; Pettignano, A.; Riela, S. Palladium nanoparticles immobilized on halloysite nanotubes covered by multilayer network for catalytic applications. New J. Chem. 2018, 42, 13938-13947. [CrossRef]

196. Ghasemi, S.; Karim, S. Organic/inorganic hybrid composed of modified polyacrylamide grafted silica supported Pd nanoparticles using RAFT polymerization process: Controlled synthesis, characterization and catalytic activity. Mater. Chem. Phys. 2018, 205, 347-358. [CrossRef]

197. Wang, W.; Chen, S.; Cal, E.G.; Moro, M.M.; Moya, S.; Coy, E.; Wang, C.; Hamon, J.-R.; Astruc, D. ZIF-8-based vs. ZIF-8-derived $\mathrm{Au}$ and Pd nanoparticles as efficient catalysts for the Ullmann homocoupling reaction. Inorg. Chem. Front. 2020, 7, $3945-3952$. [CrossRef]

198. Yasukawa, T.; Zhu, Z.; Yamashita, Y.; Kobayashi, S. Carbonylative Suzuki-Miyaura coupling reactions of aryl iodides with readily available polymer-immobilized palladium nanoparticles. Synlett 2021, 32, 502-504. [CrossRef]

199. Miyamura, H.; Yasukawa, T.; Zhu, Z.; Kobayashi, S. Asymmetric 1,4-addition of arylboronic acids to $\beta, \gamma$-unsaturated $\alpha$-ketoesters using heterogeneous chiral metal nanoparticle systems. Adv. Synth. Catal. 2020, 362, 353-359. [CrossRef]

200. Sadeghzadeh, S.M.; Zhiani, R.; Emrani, S. Pd/APTPOSS@KCC-1 as a new and efficient support catalyst for C-H activation. RSC Adv. 2017, 7, 24885-24894. [CrossRef]

201. Şen, B.; Akdere, E.H.; Şavk, A.; Gültekin, E.; Parali, Ö.; Göksu, H.; Şen, F. A novel thiocarbamide functionalized graphene oxide supported bimetallic monodisperse Rh-Pd nanoparticles (RhPd/TC@GO NPs) for Knoevenagel condensation of aryl aldehydes together with malononitrile. Appl. Catal. B Environ. 2018, 225, 148-153. [CrossRef] 
202. Subudhi, S.; Mansingh, S.; Tripathy, S.P.; Mohanty, A.; Mohapatra, P.; Rath, D.; Parida, K. The fabrication of Au/Pd plasmonic alloys on UiO-66- $\mathrm{NH}_{2}$ : An efficient visible light-induced photocatalyst towards the Suzuki Miyaura coupling reaction under ambient conditions. Catal. Sci. Technol. 2019, 9, 6585-6597. [CrossRef]

203. Sahoo, M.; Mansingh, S.; Subudhi, S.; Mohapatra, P.; Parida, K. A plasmonic AuPd bimetallic nanoalloy decorated over a GO/LDH hybrid nanocomposite via a green synthesis route for robust Suzuki coupling reactions: A paradigm shift towards a sustainable future. Catal. Sci. Technol. 2019, 9, 4678-4692. [CrossRef]

204. Luo, Y.; Peng, Y.; Liu, W.; Chen, F.; Wang, B. Soluble inorganic nanoparticle constructed porous coordination frameworks as homogenized heterogeneous photocatalysts for Suzuki coupling reaction under near-infrared light. Chem. Eur. J. 2017, 23, 8879-8885. [CrossRef]

205. Hoseinim, C.; Seyede, M.; Adadi, S.; Heravi, M.M. Application of bimetallic and trimetallic nanoparticles supported on graphene as novel heterogeneous catalysts in the reduction of nitroarenes, homo-coupling, Suzuki-Miyaura and Sonogashira reactions. Curr. Org. Chem. 2020, 24, 2216-2234. [CrossRef]

206. Zhao, M.; Wu, Y.; Cao, J.-P. Carbon-based material-supported palladium nanocatalysis in coupling reactions: Discussion on their stability and heterogeneity. Appl. Organomet. Chem. 2020, 34, e5539. [CrossRef]

207. Nasrollahzadeh, M.; Issaabadi, Z.; Tohidi, M.M.; Sajadi, S.M. Recent progress in application of graphene supported metal nanoparticles in C-C and C-X coupling reactions. Chem. Rec. 2018, 18, 165-229. [CrossRef]

208. Labulo, A.H.; Martincigh, B.S.; Omondi, B.; Nyamori, V.O. Advances in carbon nanotubes as efficacious supports for palladiumcatalyzed carbon-carbon cross-coupling reactions. J. Mater. Sci. 2017, 52, 9225-9248. [CrossRef]

209. Anastasiou, I.; Ferlin, F.; Viteritti, O.; Santoro, S.; Vaccaro, L. Pd/C-catalyzed aerobic oxidative C-H alkenylation of arenes in $\gamma$-valerolactone (GVL). Mol. Catal. 2021, 513, 111787. [CrossRef]

210. Campana, F.; Massaccesi, B.M.; Santoro, S.; Piermatti, O.; Vaccaro, L. Polarclean/water as a safe and recoverable medium for selective C2-arylation of indoles catalyzed by Pd/C. ACS Sustain. Chem. Eng. 2020, 8, 16441-16450. [CrossRef] [PubMed]

211. Bhattacharjee, P.; Boruah, P.K.; Das, M.R.; Bora, U. Direct C-H bond activation: Palladium-on-carbon as a reusable heterogeneous catalyst for C-2 arylation of indoles with arylboronic acid. New J. Chem. 2020, 44, 7675-7682. [CrossRef]

212. Shabestari, M.E.; Martín, O.; Díaz-García, D.; Gómez-Ruiz, S.; Gonzalez, V.J.; Baselga, J. Facile and rapid decoration of graphene oxide with copper double salt, oxides and metallic copper as catalysts in oxidation and coupling reactions. Carbon 2020, 161, 7-16. [CrossRef]

213. Sultana, S.; Mech, S.D.; Hussain, F.L.; Pahari, P.; Borah, G.; Gogoi, P.K. Green synthesis of graphene oxide (GO)-anchored $\mathrm{Pd} / \mathrm{Cu}$ bimetallic nanoparticles using Ocimum sanctum as bio-reductant: An efficient heterogeneous catalyst for the Sonogashira cross-coupling reaction. RSC Adv. 2020, 10, 23108-23120. [CrossRef]

214. Pang, Q.; Fan, X. Facile synthesis for anchoring highly efficient superfine Pd nanoparticles on carbon: Boosting catalytic C-C coupling. ChemistrySelect 2020, 5, 7959-7966. [CrossRef]

215. Saptal, V.B.; Saptal, M.V.; Mane, R.S.; Sasaki, T.; Bhanage, B.M. Amine-functionalized graphene oxide-stabilized Pd nanoparticles (Pd@APGO): A novel and efficient catalyst for the Suzuki and carbonylative Suzuki-Miyaura coupling reactions. ACS Omega 2019, 4, 643-649. [CrossRef]

216. Golestanzadeh, M.; Naeimi, H. Palladium decorated on a new dendric complex with nitrogen ligation grafted to graphene oxide: Fabrication, characterization, and catalytic application. RSC Adv. 2019, 9, 27560-27573. [CrossRef]

217. Kumari, S.; Mittal, A.; Kumar, A.; Sharma, S.K.; Parmanand; Krishna. Palladium nanoparticles immobilized on Schiff base-functionalized graphene-oxide: Application in carbon-carbon cross-coupling reactions. ChemistrySelect 2019, 4, 1082810837. Available online: https://chemistry-europe.onlinelibrary.wiley.com/doi/10.1002/slct.201902242 (accessed on 10 September 2021).

218. Mohazzab, B.F.; Jaleh, B.; Issaabadi, Z.; Nasrollahzadeh, M.; Varma, R.S. Stainless steel mesh-GO/Pd NPs: Catalytic applications of Suzuki-Miyaura and Stille coupling reactions in eco-friendly media. Green Chem. 2019, 21, 3319-3327. [CrossRef]

219. Lu, W.; Sun, W.; Tan, X.; Gao, L.; Zheng, G. Stabilized Cu/ $\mathrm{Cu}_{2} \mathrm{O}$ nanoparticles on $\mathrm{rGO}$ as an efficient heterogeneous catalyst for Glaser homo-coupling. Catal. Commun. 2019, 125, 98-102. [CrossRef]

220. Beigbaghlou, S.S.; Kalbasi, R.J.; Habibi, A. Ni-Pd nanoparticles embedded in N-doped hierarchical porous carbon derived from Luffa sponge: Preparation, characterization and its catalytic activity. ChemistrySelect 2019, 4, 12875-12885. [CrossRef]

221. Trzeciak, A.M.; Wojcik, P.; Lisiecki, R.; Gerasymchuk, Y.; Strek, W.; Legendziewicz, J. Palladium nanoparticles supported on graphene oxide as catalysts for the synthesis of diarylketones. Catalysts 2019, 9, 319. [CrossRef]

222. Veisi, H.; Tamoradi, T.; Karmakar, B.; Mohammadi, P.; Hemmati, S. In situ biogenic synthesis of Pd nanoparticles over reduced graphene oxide by using a plant extract (Thymbra spicata) and its catalytic evaluation towards cyanation of aryl halides. Mater. Sci. Eng. C 2019, 104, 109919. [CrossRef]

223. Shi, X.; Cai, C. Imidazolium-based ionic liquid functionalized reduced graphene oxide supported palladium as a reusable catalyst for Suzuki-Miyaura reactions. New J. Chem. 2018, 42, 2364-2367. [CrossRef]

224. Poly, S.S.; Hakim Siddiki, S.M.A.; Touchy, A.S.; Ting, K.W.; Toyao, T.; Maeno, Z.; Kanda, Y.; Shimizu, K. Acceptorless dehydrogenative synthesis of pyrimidines from alcohols and amidines catalyzed by supported platinum nanoparticles. ACS Catal. 2018, 8, 11330-11341. [CrossRef] 
225. Elazab, H.A.; Moussa, S.; Siamaki, A.R.; Gupton, B.F.; El-Shall, M.S. The effect of graphene on catalytic performance of palladium nanoparticles decorated with $\mathrm{Fe}_{3} \mathrm{O}_{4}, \mathrm{Co}_{3} \mathrm{O}_{4}$, and $\mathrm{Ni}(\mathrm{OH})_{2}$ : Potential efficient catalysts used for Suzuki cross-coupling. Catal. Lett. 2017, 147, 1510-1522. [CrossRef]

226. Sarvestani, M.; Azadi, R. Palladium nanoparticles deposited on a graphene-benzimidazole support as an efficient and recyclable catalyst for aqueous-phase Suzuki-Miyaura coupling reaction. Appl. Organomet. Chem. 2017, 31, e3667. [CrossRef]

227. Hoseini, S.J.; Agahi, B.H.; Fard, Z.S.; Fath, R.H.; Bahrami, M. Modification of palladium-copper thin film by reduced graphene oxide or platinum as catalyst for Suzuki-Miyaura reactions. Appl. Organomet. Chem. 2017, 31, e3607. [CrossRef]

228. Kwon, T.H.; Cho, K.Y.; Baek, J.-Y.; Yoon, H.G.; Kim, B.M. Recyclable palladium-graphene nanocomposite catalysts containing ionic polymers: Efficient Suzuki coupling reactions. RSC Adv. 2017, 7, 11684-11690. [CrossRef]

229. Lamei, K.; Eshghi, H.; Bakavoli, M.; Rounaghi, S.A.; Esmaeili, E. Carbon coated copper nanostructures as a green and ligand free nanocatalyst for Suzuki cross-coupling reaction. Catal. Commun. 2017, 92, 40-45. [CrossRef]

230. Erami, R.S.; Díaz-García, D.; Prashar, S.; Rodríguez-Diéguez, A.; Fajardo, M.; Amirnasr, M.; Gómez-Ruiz, S. Suzuki-Miyaura C-C coupling reactions catalyzed by supported Pd nanoparticles for the preparation of fluorinated biphenyl derivatives. Catalysts 2017, 7, 76. [CrossRef]

231. Mahanta, A.; Hussain, N.; Das, M.R.; Thakur, A.J.; Bora, U. Palladium nanoparticles decorated on reduced graphene oxide: An efficient catalyst for ligand- and copper-free Sonogashira reaction at room temperature. Appl. Organomet. Chem. 2017, 31, e3679. [CrossRef]

232. Nan, L.; Yalan, C.; Jixiang, L.; Dujuan, O.; Wenhui, D.; Rouhi, J.; Mustapha, M. Carbonylative Suzuki-Miyaura cross-coupling by immobilized Ni@Pd NPs supported on carbon nanotubes. RSC Adv. 2020, 10, 27923-27931. [CrossRef]

233. Hajipour, A.R.; Khorsandi, Z.; Farrokhpour, H. In situ synthesis of carbon nanotube-encapsulated cobalt nanoparticles by a novel and simple chemical treatment process: Efficient and green catalysts for the Heck reaction. New J. Chem. 2019, 43, 8215-8219. [CrossRef]

234. Gopiraman, M.; Saravanamoorthy, S.; Ullah, S.; Ilangovan, A.; Kim, I.S.; Chung, I.M. Reducing-agent-free facile preparation of Rh-nanoparticles uniformly anchored on onion-like fullerene for catalytic applications. RSC Adv. 2020, 10, 2545-2559. [CrossRef]

235. Yu, Q.-Y.; Su, H.; Zhai, G.-Y.; Zhang, S.-N.; Sun, L.-H.; Chen, J.-S.; Li, X.-H. Designed electron-deficient gold nanoparticles for a room-temperature $\mathrm{Csp}^{3}-\mathrm{Csp}^{3}$ coupling reaction. Chem. Commun. 2021, 57, 741-744. [CrossRef]

236. Wang, C.; Salmon, L.; Ciganda, R.; Yate, L.; Moya, S.; Ruiz, J.; Astruc, D. An efficient parts-per-million $\alpha-\mathrm{Fi}_{2} \mathrm{O}_{3}$ nanocluster/graphene oxide catalyst for Suzuki-Miyaura coupling reactions and 4-nitrophenol reduction in aqueous solution. Chem. Commun. 2017, 53, 644-646. [CrossRef]

237. Tran, T.P.N.; Thakur, A.; Trinh, D.X.; Dao, A.T.N.; Taniike, T. Design of Pd@graphene oxide framework nanocatalyst with improved activity and recyclability in Suzuki-Miyaura cross-coupling reaction. Appl. Catal. A Gem. 2018, 549, 60-67. [CrossRef]

238. Zhang, Q.; Mao, Z.; Wang, K.; Phan, N.T.S.; Zhang, F. Microwave-assisted aqueous carbon-carbon cross-coupling reactions of aryl chlorides catalyzed by reduced graphene oxide supported palladium nanoparticles. Green Chem. 2020, 22, 3239-3247. [CrossRef]

239. Fatahi, P.; Hoseini, S.J. Formation of PdNiZn thin film at oil-water interface: XPS study and application as Suzuki-Miyaura catalyst. Appl. Organomet. Chem. 2018, 32, e4187. [CrossRef]

240. Murugan, K.; Nainamalai, D.; Kanagaraj, P.; Nagappan, S.G.; Palaniswamy, S. Green-synthesized nickel nanoparticles on reduced graphene oxide as an active and selective catalyst for Suzuki and Glaser-Hay coupling reactions. Appl. Organomet. Chem. 2020, e5778. [CrossRef]

241. Blanco, M.; Mosconi, D.; Tubaro, C.; Biffis, A.; Badocco, D.; Pastore, P.; Otyepka, M.; Bakandritsos, A.; Liu, Z.; Ren, W.; et al. Palladium nanoparticles supported on graphene acid: A stable and eco-friendly bifunctional C-C homo- and cross-coupling catalyst. Green Chem. 2019, 21, 5238-5247. [CrossRef]

242. Dabiri, M.; Kashi, S.R.B.; Lehi, N.F.; Bashiribod, S. Synthesis of gold nanoparticles decorated on sulfonated three-dimensional graphene nanocomposite and application as a highly efficient and recyclable heterogeneous catalyst for Ullmann homocoupling of aryl iodides and reduction of $p$-nitrophenol. Appl. Organomet. Chem. 2018, 32, e4189. [CrossRef]

243. Dabiri, M.; Vajargahy, M.P. PdCo bimetallic nanoparticles supported on three-dimensional graphene as a highly active catalyst for Sonogashira cross-coupling reaction. Appl. Organomet. Chem. 2017, 31, e3594. [CrossRef]

244. Siddiki, S.M.A.H.; Touchy, A.S.; Jamil, M.A.R.; Toyao, T.; Shimizu, K. C-methylation of alcohols, ketones, and indoles with methanol using heterogeneous platinum catalysts. ACS Catal. 2018, 8, 3091-3103. [CrossRef]

245. Kramer, S.; Hejjo, F.; Rasmussen, K.H.; Kegnæs, S. Silylative pinacol coupling catalyzed by nitrogen-doped carbon-encapsulated nickel/cobalt nanoparticles: Evidence for a silyl radical pathway. ACS Catal. 2018, 8, 754-759. [CrossRef]

246. Wang, N.; Ma, L.; Wang, J.; Zhang, Y.; Jiang, R. Graphitic carbon nitride $\left(\mathrm{g}-\mathrm{C}_{3} \mathrm{~N}_{4}\right)$ supported Pd species: An efficient heterogeneous photocatalyst surpassing homogeneous thermal heating systems for Suzuki coupling. ChemPlusChem 2019, 84, 1164-1168. [CrossRef]

247. Movahed, S.K.; Miraghaee, S.; Dabiri, M. AuPd alloy nanoparticles decorated graphitic carbon nitride as an excellent photocatalyst for the visible-light-enhanced Suzuki-Miyaura cross-coupling reaction. J. Alloy. Compd. 2020, 819, 152994. [CrossRef]

248. Kang, E.; Shin, H.H.; Lim, D.-K. Interface-controlled Pd nanodot-Au nanoparticle colloids for efficient visible-light-induced photocatalytic Suzuki-Miyaura coupling reaction. Catalysts 2018, 8, 463. [CrossRef]

249. Li, Y.; Hong, X.M.; Collard, D.M.; El-Sayed, M.A. Suzuki cross-coupling reactions catalyzed by palladium nanoparticles in aqueous solution. Org. Lett. 2000, 2, 2385-2388. [CrossRef] 
250. Zhao, M.; Sun, L.; Crooks, R.M. Preparation of $\mathrm{Cu}$ nanoclusters within dendrimer templates. J. Am. Chem. Soc. 1998, 120, 4877-4878. [CrossRef]

251. Balogh, L.; Tomalia, D.A. Poly(amidoamine) dendrimer-templated nanocompsites. 1. Synthesis of zerovalent copper nanoclusters. J. Am. Chem. Soc. 1998, 120, 7355-7356. [CrossRef]

252. Esumi, K.; Suzuki, A.; Aihara, N.; Usui, K.; Torigoe, K. Preparation of gold colloids with UV irradiation using dendrimers as stabilizer. Langmuir 1998, 14, 3157-3159. [CrossRef]

253. Jadoun, S.; Arif, R.; Jangid, N.K.; Meena, R.K. Green synthesis of nanoparticles using plant extracts: A review. Environ. Chem. Lett. 2021, 19, 355-374. [CrossRef]

254. Favier, I.; Pia, D.; Gómez, M. Palladium nanoparticles in polyols: Synthesis, catalytic couplings, and hydrogenations. Chem. Rev. 2020, 120, 1146-1183. [CrossRef]

255. Wolfson, A.; Levy-Ontman, O. Development and application of palladium nanoparticles on renewable polysaccharides as catalysts for the Suzuki cross-coupling of halobenzenes and phenylboronic acids. Mol. Catal. 2020, 493, 111048. [CrossRef]

256. Yasukawa, T.; Miyamura, H.; Kobayashi, S. Chiral rhodium nanoparticle-catalyzed asymmetric arylation reactions. Acc. Chem. Res. 2020, 53, 2950-2963. [CrossRef] [PubMed]

257. Nasrollahzadeh, M.; Ghorbannezhad, F.; Issaabadi, Z.; Sajadi, S.M. Recent developments in the biosynthesis of Cu-based recyclable nanocatalysts using plant extracts and their application in the chemical reactions. Chem. Rec. 2019, 19, 601-643. [CrossRef] [PubMed]

258. Nasrollahzadeh, M.; Yek, S.M.-G.; Motahharifar, N.; Gorab, M.G. Recent development in the plant-mediated green synthesis of Ag-based nanoparticles for environmental and catalytic applications. Chem. Rec. 2019, 19, 2436-2479. [CrossRef]

259. Ferlin, F.; Valentini, F.; Sciosci, D.; Calamante, M.; Petricci, E.; Vaccaro, L. Biomass waste-derived Pd-PiNe catalyst for the continuous-flow copper-free Sonogashira reaction in a CPME-water azeotropic mixture. ACS Sustain. Chem. Eng. 2021, 9, 12196-12204. [CrossRef]

260. Valentini, F.; Ferlin, F.; Lilli, S.; Marrocchi, A.; Ping, L.; Gu, Y.; Vaccaro, L. Valorisation of urban waste to access low-cost heterogeneous palladium catalysts for cross-coupling reactions in biomass-derived $\gamma$-valerolactone. Green Chem. 2021, 23, 5887-5895. [CrossRef]

261. Valentini, F.; Ferlin, F.; Tomarelli, E.; Mahmoudi, H.; Bagherzadeh, M.; Calamante, M.; Vaccaro, L. A waste-minimized approach to Cassar-Heck reaction based on POLITAG-Pd ${ }^{0}$ heterogeneous catalyst and recoverable acetonitrile azeotrope. ChemSusChem 2021, 14, 3359-3366. [CrossRef]

262. Dos Santos, R.V.; Vitoi, V.H.M.; Casta, M.V.; da Silva, L.C.L.L.F.; Archanjo, B.S.; Achete, C.A.; Silva, R.S.F.; Aguiar, L.C.S.; Malta, L.F.B.; Senra, J.D. Thermoresponsive starch hydrogel stabilized Pd nanoparticles: Soft catalyst for the preparation of ( \pm )- $\alpha$-methylbiphenylalanine in water aiming at bioorthogonal chemistries. Catal. Lett. 2021, 151, 844-852. [CrossRef]

263. Úbeda, M.Á.; Amorós, P.; Sánhez-Royo, J.F.; Haskouri, J.E.; Marcos, M.D.; Pérez-Pla, F. Precatalyst or dosing-device? The $\left[\mathrm{Pd}_{2}\left\{\mu-\left(\mathrm{C}_{6} \mathrm{H}_{4}\right) \mathrm{PPh}_{2}\right\}_{2}\left\{\mu-\mathrm{O}_{2} \mathrm{C}\left(\mathrm{C}_{6} \mathrm{H}_{5}\right)\right\}_{2}\right]$ complex anchored on a carboxypolystyrene polymer as an effective supplier of palladium catalytically active nanoparticles for the Suzuki-Miyaura reaction. J. Catal. 2020, 381, 26-37. [CrossRef]

264. Patel, S.B.; Vasava, D.V. The study on encapsulation of copper nanoparticles in modified poly-styrene resin matrix and its catalytic evaluation in microwave-assisted Sonogashira coupling. ChemistrySelect 2020, 5, 7040-7048. [CrossRef]

265. Tirumala, R.T.A.; Dadgar, A.P.; Mohammadparast, F.; Ramakrishnan, S.B.; Mou, T.; Wang, B.; Andiappan, M. Homogeneous versus heterogeneous catalysis in $\mathrm{Cu}_{2} \mathrm{O}$-nanoparticle-catalyzed C-C coupling reactions. Green Chem. 2019, 21, 5284-5290. [CrossRef]

266. Chopra, R.; Kumar, M.; Neelam Bhalla, V. Visible light promoted PANI@Au:CuO catalyzed sequential amination, azidation and annulation for the preparation of 2-arylbenzimidazoles. Green Chem. 2019, 21, 3666-3674. [CrossRef]

267. Ferlin, F.; Yetra, S.R.; Warratz, S.; Vaccaro, L.; Ackermann, L. Reusable Pd@PEG catalyst for aerobic dehydrogenative C-H/C-H arylations of 1,2,3-triazoles. Chem. Eur. J. 2019, 25, 11427-11431. [CrossRef]

268. Valentini, F.; Mahmoudi, H.; Bivona, L.A.; Piermatti, O.; Bagherzadeh, M.; Fusaro, L.; Aprile, C.; Marrocchi, A.; Vaccaro, L. Polymer-supported bis-1,2,4-triazolium ionic tag framework for an efficient $\mathrm{Pd}(0)$ catalytic system in biomass derived $\gamma$-valerolactone. ACS Sustain. Chem. Eng. 2019, 7, 6939-6946. [CrossRef]

269. Zhang, W.; Yao, Z.-J.; Deng, W. Palladium nanoparticles supported on $\beta$-cyclodextrin functionalized poly(amidoamine)s and their application in Suzuki-Miyaura cross-coupling reactions. J. Braz. Chem. Soc. 2019, 30, 1667-1677. [CrossRef]

270. Sarmah, M.; Neog, A.B.; Boruah, P.K.; Das, M.R.; Bharali, P.; Bora, U. Effect of substrates on catalytic activity of biogenic palladium nanoparticles in C-C cross-coupling reactions. ACS Omega 2019, 4, 3329-3340. [CrossRef]

271. Ghasemi, S.; Harandi, Z.A. PdNPs@thermo-responsive block copolymers composed of PNIPAM and poly(ionic liquid) via RAFT polymerization. Polym. Bull. 2019, 76, 2819-2834. [CrossRef]

272. Veisi, H.; Dadres, N.; Mohammadi, P.; Hemmati, S. Green synthesis of silver nanoparticles based on oil-water interface method with essential oil of orange peel and its application as nanocatalyst for $\mathrm{A}^{3}$ coupling. Matel. Sci. Eng. C 2019, 105, 110031. [CrossRef] [PubMed]

273. Viesi, H. Efficient cyanation of aryl halides with $\mathrm{K}_{4}\left[\mathrm{Fe}(\mathrm{CN})_{6}\right]$ catalyzed by encapsulated palladium nanoparticles in biguanidinechitosan matrix as core-shell recyclable heterogeneous nanocatalyst. Polyhedron 2019, 159, 212-216. [CrossRef]

274. Singh, G.; Kumar, M.; Bhalla, V. Ultrafine hybrid $\mathrm{Cu}_{2} \mathrm{O}-\mathrm{Fe}_{2} \mathrm{O}_{3}$ nanoparticles stabilized by hexaphenylbenzene-based supramolecular assembles: A photocatalytic system for the Ullmann-Goldberg coupling reaction. Green Chem. 2018, 20, 5346-5357. [CrossRef] 
275. Kaur, N.; Kaur, G.; Bhalla, A.; Dhau, J.S.; Chaudhary, G.R. Metallosurfactant based Pd-Ni alloy nanoparticles as a proficient catalyst in the Mizoroki Heck coupling reaction. Green Chem. 2018, 20, 1506-1514. [CrossRef]

276. Alsalahi, W.; Tylus, W.; Trzeciak, A.M. Green synthesis of rhodium nanoparticles, catalytically active in benzene hydrogenation and 1-hexene hydroformylation. ChemCatChem 2018, 10, 2051-2058. [CrossRef]

277. Lu, Z.; Jasinski, J.B.; Handa, S.; Hammond, G.B. Recyclable-cellulose-palladium nanoparticles for clean cross-coupling chemistry. Org. Biomol. Chem. 2018, 16, 2748-2752. [CrossRef]

278. Jebali, Z.; Granados, A.; Nabili, A.; Boufi, S.; do Rego, A.M.B.; Majboub, H.; Vallribera, A. Cationic cellulose nanofibrils as a green support of palladium nanoparticles: Catalyst evaluation in Suzuki reactions. Cellulose 2018, 25, 6963-6975. [CrossRef]

279. Dewan, A.; Sarmah, M.; Thakur, A.J.; Bharali, P.; Bora, U. Greener biogenic approach for the synthesis of palladium nanoparticles using papaya peel: An eco-friendly catalyst for C-C coupling reaction. ACS Omega 2018, 3, 5327-5335. [CrossRef]

280. Chatterjee, S.; Bhattacharya, S.K. Size-dependent catalytic activity and fate of palladium nanoparticles in Suzuki-Miyaura coupling reactions. ACS Omega 2018, 3, 12905-12913. [CrossRef]

281. Kandathil, V.; Dateer, R.B.; Sasidhar, B.S.; Patil, S.A.; Patil, S.A. Green synthesis of palladium nanoparticles: Applications in aryl halide cyanation and Hiyama cross-coupling reaction under ligand free conditions. Catal. Lett. 2018, 148, 1562-1578. [CrossRef]

282. Gaikwad, D.S.; Undale, K.A.; Patil, D.B.; Pore, D.M.; Kamble, A.A. Triton X-100 stabilized Pd nanoparticles and their catalytic application in one-pot sequential Heck and Hiyama coupling in water. Res. Chem. Intermed. 2018, 44, 265-275. [CrossRef]

283. Kuchkina, N.V.; Rajadurai, M.; Pal, M.; Basaveni, S.; Sorokina, S.A.; Krasnova, I.Y.; Serkova, E.S.; Shifrina, Z.B. Catalysts cased on hyperbranched pyridylphenylene polymers and palladium nanoparticles for the Suzuki-Miyaura cross-coupling reaction. Russ. Chem. Bull. Int. Ed. 2018, 67, 1035-1040. [CrossRef]

284. Veisi, H.; Farokhi, M.; Hamelian, M.; Hemmati, S. Green synthesis of Au nanoparticles using an aqueous extract of Stachys lavandulifolia and their catalytic performance for alkyne/aldehyde/amine $\mathrm{A}^{3}$ coupling reactions. RSC Adv. 2018, 8, 38186-38195. [CrossRef]

285. Veisi, H.; Mirshokraie, S.A.; Ahmadian, H. Synthesis of biaryls using palladium nanoparticles immobilized on metforminefunctionalized polystyrene resin as a reusable and efficient nanocatalyst. Int. J. Biol. Macromol. 2018, 108, 419-425. [CrossRef]

286. Veisi, H.; Adib, M.; Karimi-Nami, R.; Yasaei, Z.; Tajik, M.; Mosavat, T.S.; Hemmati, S. Suzuki-Miyaura coupling catalyzed by palladium nanoparticles biosynthesized using Glycyrrhiza glabra as reducing and stabilizing agent. Appl. Organomet. Chem. 2018, 32, e4138. [CrossRef]

287. Ghasemi, S.; Karim, S. Controlled synthesis of modified polyacrylamide grafted nano-sized supported Pd nanoparticles via RAFT polymerization through "grafting to" approach: Application to the Heck reaction. Colloid Polym. Sci. 2018, 296, 1323. [CrossRef]

288. Ghasemi, S.; Harandi, Z.A. Thermo-responsive poly( $N$-isopropylacrylamide)-block-poly(ionic liquid) of pyridinium sulfonate immobilized Pd nanoparticles in C-C coupling reactions. RSC Adv. 2018, 8, 14570-14578. [CrossRef]

289. Baran, T.; Baran, N.Y.; Menteş, A. Sustainable chitosan/starch composite material for stabilization of palladium nanoparticles: Synthesis, characterization and investigation of catalytic behaviour of Pd@chitosan/starch nanocomposite in Suzuki-Miyaura reaction. Appl. Organomet. Chem. 2017, 31, e4075. [CrossRef]

290. Dewan, A.; Sarmah, M.; Bora, U.; Thakur, A.J. In situ generation of palladium nanoparticles using agro waste and their use as catalyst for copper-, amine- and ligand-free Sonogashira reaction. Appl. Organomet. Chem. 2017, 31, e3646. [CrossRef]

291. Veisi, H.; Rostami, A.; Shirinbayan, M. Greener approach for synthesis of monodispersed palladium nanoparticles using aqueous extract of green tea and their catalytic activity for the Suzuki-Miyaura coupling reaction and the reduction of nitroarenes. Appl. Organomet. Chem. 2017, 31, e3609. [CrossRef]

292. Dong, Y.; Wu, X.; Chen, X.; Wei, Y. N-Methylimidazole functionalized carboxymethylcellulose-supported Pd catalyst and its applications in Suzuki cross-coupling reaction. Carbohyd. Polym. 2017, 160, 106-114. [CrossRef] [PubMed]

293. Kumara, K.S.J.; Krishnamurthy, G.; Swamy, B.E.K.; Kumar, N.S.; Kumar, M. Catalytic performance study of nano-cobalt: A catalyst for complement to the Heck coupling reaction. J. Porous Mater. 2017, 24, 1095-1103. [CrossRef]

294. Tarnowicz, S.; Alsalahi, W.; Mieczynska, E.; Trzeciak, A.M. Heck arylation of allyl alcohol catalyzed by Pd(0) nanoparticles. Tetrahedron 2017, 73, 5605-5612. [CrossRef]

295. Huang, T.; Sheng, G.; Manchanda, P.; Emwas, A.H.; Lai, Z.; Nunes, S.P.; Peinemann, K.-V. Cyclodextrin polymer networks decorated with subnanometer metal nanoparticles for high-performance low-temperature catalysis. Sci. Adv. 2019, 5, eaax6976. [CrossRef] [PubMed]

296. Doherty, S.; Knight, J.G.; Backhouse, T.; Abood, E.; Al-shaikh, H.; Clemmet, A.R.; Ellison, J.R.; Bourne, R.A.; Chamberlain, T.W.; Stones, R.; et al. Heteroatom donor-decorated polymer-immobilized ionic liquid stabilized palladium nanoparticles: Efficient catalysts for room-temperature Suzuki-Miyaura cross-coupling in aqueous media. Adv. Synth. Catal. 2018, 360, $3716-3731$. [CrossRef]

297. Kunfi, A.; May, Z.; Németh, P.; London, G. Polydopamine supported palladium nanoparticles: Highly efficient catalysts in Suzuki cross-coupling and tandem Suzuki cross-coupling/nitroarene reductions under green conditions. J. Catal. 2018, 361, 84-93. [CrossRef]

298. Borah, R.K.; Mahanta, A.; Dutta, A.; Bora, U.; Thakur, A.J. A green synthesis of palladium nanoparticles by Sapindus mukorossi seed extract and use in efficient room temperature Suzuki-Miyaura cross-coupling reaction. Appl. Organomet. Chem. 2017, 31, e3784. [CrossRef] 
299. Mäsing, F.; Nüsse, H.; Klingauf, J.; Studer, A. Visible-light-enabled preparation of palladium nanoparticles and application as catalysts for Suzuki-Miyaura coupling. Org. Lett. 2018, 20, 752-755. [CrossRef]

300. Chen, Y.; Wang, M.; Zhang, L.; Liu, Y.; Han, J. Poly(o-aminothiophenol)-stabilized Pd nanoparticles as efficient heterogeneous catalysts for Suzuki cross-coupling reactions. RSC Adv. 2017, 7, 47104-47110. [CrossRef]

301. Kim, Y.O.; You, J.M.; Jang, H.-S.; Choi, S.K.; Jung, B.Y.; Kang, O.; Kim, J.W.; Lee, Y.-S. Eumelanin as a support for efficient palladium nanoparticle catalyst for Suzuki coupling reaction of aryl chlorides in water. Tetrahedron Lett. 2017, 58, $2149-2152$. [CrossRef]

302. Yan, X.; Luo, Y.; Liu, W.; Liang, L.; Gan, Y.; Chen, Z.; Xu, Z.; Wan, H.; Tang, D.; Shi, H.; et al. Strategy used to synthesize high activity and low Pd catalyst for Suzuki coupling reaction: An experimental and theoretical investigation. Phys. Chem. Chem. Phys. 2020, 22, 6222-6230. [CrossRef]

303. Wan, J.; Fan, B.; Thang, S.H. Sonochemical preparation of polymer-metal nanocomposites with catalytic and plasmonic properties. Nanoscale Adv. 2021, 3, 3306-3315. [CrossRef]

304. Llevot, A.; Monney, B.; Sehlinger, A.; Behrens, S.; Meier, M.A.R. Highly efficient Tsuji-Trost allylation in water catalyzed by Pd-nanoparticles. Chem. Commun. 2017, 53, 5175-5178. [CrossRef]

305. Wang, Y.; Yang, X.; Yu, J. A polysalen based on polyacrylamide stabilized palladium nanoparticle catalyst for efficient carbonylative Sonogashira reaction in aqueous media. RSC Adv. 2017, 7, 31850-31857. [CrossRef]

306. Piras, C.C.; Slavik, P.; Smith, D.K. Self-assembling supramolecular hybrid hydrogel beads. Angew. Chem. Int. Ed. 2020, 59, 853-859. [CrossRef] [PubMed]

307. Slavik, P.; Smith, D.K. Hybrid hydrogels loaded with palladium nanoparticles-catalysts for environmentally-friendly Sonogashira and Heck cross-coupling reactions. Tetrahedron 2020, 76, 131344. [CrossRef]

308. Slavik, P.; Kurka, D.W.; Smith, D.K. Palladium-scavenging self-assembled hybrid hydrogels-reusable highly-active green catalysts for Suzuki-Miyaura cross-coupling reactions. Chem. Sci. 2018, 9, 8673-8681. [CrossRef]

309. Ohtaka, A.; Kawase, M.; Usami, A.; Fukui, S.; Yamashita, M.; Yamaguchi, K.; Sakon, A.; Shiraki, T.; Ishida, T.; Nagata, S.; et al. Mechanistic study on allylic arylation in water with linear polystyrene-stabilized Pd and PdO nanoparticles. ACS Omega 2019, 4, 15764-15770. [CrossRef] [PubMed]

310. Ohtaka, A.; Kawase, M.; Aihara, S.; Miyamoto, Y.; Terada, A.; Nakamura, K.; Hamasaka, G.; Uozumi, Y.; Shinagawa, T.; Shimomura, O.; et al. Poly(tetrafluoroethylene)-stabilized metal nanoparticles: Preparation and evaluation of catalytic activity for Suzuki, Heck, and arene hydrogenation in water. ACS Omega 2018, 3, 10066-10073. [CrossRef] [PubMed]

311. Ohtaka, A.; Fukui, S.; Sakon, A.; Hamasaka, G.; Uozumi, Y.; Shinagawa, T.; Shimomura, O.; Nomura, R. Linea polystyrenestabilized $\mathrm{Rh}(\mathrm{III})$ nanoparticles for oxidative coupling of arylboronic acids with alkenes in water. J. Organomet. Chem. 2018, 873, 1-7. [CrossRef]

312. Ohtaka, A.; Sakon, A.; Yasui, A.; Kawaguchi, T.; Hamasaka, G.; Uozumi, Y.; Shinagawa, T.; Shimomura, O.; Nomura, R. Catalytic specificity of linear polystyrene-stabilized Pd nanoparticles during Ullmann coupling reaction in water and the associated mechanism. J. Organomet. Chem. 2018, 854, 87-93. [CrossRef]

313. Sakon, A.; Ii, R.; Hamasaka, G.; Uozumi, Y.; Shinagawa, T.; Shimomura, O.; Nomura, R.; Ohtaka, A. Detailed mechanism for Hiyama coupling reaction in water catalyzed by linear polystyrene-stabilized PdO nanoparticles. Organometallics 2017, 36, 1618-1622. [CrossRef]

314. Da Costa, A.P.; Nunes, D.R.; Tharaud, M.; Oble, J.; Poli, G.; Rieger, J. Pd(0)-nanoparticles embedded in core-shell nanogels as recoverable catalysts for the Mizoroki-Heck reaction. ChemCatChem 2017, 9, 2167-2175. [CrossRef]

315. Pang, H.; Hu, Y.; Yu, J.; Gallou, F.; Lipshutz, B.H. Water-sculpting of a heterogeneous nanoparticle precatalyst for Mizoroki-Heck couplings under aqueous micellar catalysis conditions. J. Am. Chem. Soc. 2021, 143, 3373-3382. [CrossRef] [PubMed]

316. Ansari, T.N.; Sharma, S.; Hazra, S.; Jasinski, J.B.; Wilson, A.J.; Hicks, F.; Leahy, D.K.; Handa, S. Shielding effect of nanomicelles: Stable and catalytically active oxidizable $\mathrm{Pd}(0)$ nanoparticle catalyst compatible for cross-couplings of water-sensitive acid chlorides in water. JACS Au 2021, 1, 1506-1513. [CrossRef] [PubMed]

317. Ansari, T.N.; Jasinski, J.B.; Leahy, D.K.; Handa, S. Metal-micelle cooperativity: Phosphine ligand-free ultrasmall palladium(II) nanoparticles for oxidative Mizoroki-Heck-type couplings in water at room temperature. JACS Au 2021, 1, 308-315. [CrossRef]

318. Bihani, M.; Ansari, T.N.; Finck, L.; Bora, P.P.; Jasinski, J.B.; Pavuluri, B.; Leahy, D.K.; Handa, S. Scalable $\alpha$-arylation of nitriles in aqueous micelles using ultrasmall Pd nanoparticles: Surprising formation of carbanion in water. ACS Catal. 2020, 10, 6816-6821. [CrossRef]

319. Petkova, D.; Borlinghaus, N.; Shama, S.; Kaschel, J.; Lindner, T.; Klee, J.; Jolit, A.; Haller, V.; Heitz, S.; Britze, K.; et al. Hydrophobic pockets of HPMC enable extremely short reaction times in water. ACS Sustain. Chem. Eng. 2020, 8, 12612-12617. [CrossRef]

320. Lee, N.; Moghadam, F.A.; Braga, F.C.; Lippincott, D.J.; Zhu, B.; Gallou, F.; Lipshutz, B.H. Sustainable palladium-catalyzed Tsuji-Trost reactions enabled by aqueous micellar catalysis. Org. Lett. 2020, 22, 4949-4954. [CrossRef]

321. Takale, B.S.; Thakore, R.R.; Irvine, N.M.; Schuitman, A.D.; Li, X.; Lipshutz, B.H. Sustainable and cost-effective Suzuki-Miyaura coupling toward the key biaryl subunits of Arylex and Rinskor active. Org. Lett. 2020, 22, 4823-4827. [CrossRef]

322. Pang, H.; Wang, Y.; Gallou, F.; Lipshutz, B.H. Fe-catalyzed reductive couplings of terminal (hetero)aryl alkenes and alkyl halides under aqueous micellar conditions. J. Am. Chem. Soc. 2019, 141, 17117-17124. [CrossRef] [PubMed]

323. Duong, U.T.; Gade, A.B.; Plummer, S.; Gallou, F.; Handa, S. Reactivity of carbenes in aqueous nanomicelles containing palladium nanoparticles. ACS Catal. 2019, 9, 10963-10970. [CrossRef] 
324. Bihani, M.; Bora, P.P.; Nachtegaal, M.; Jasinski, J.B.; Plummer, S.; Gallou, F.; Handa, S. Microballs containing Ni(0)Pd(0) NPs for highly selective micellar catalysis in water. ACS Catal. 2019, 9, 7520-7526. [CrossRef]

325. Lee, N.R.; Linstadt, R.T.H.; Gloisten, D.J.; Gallou, F.; Lipshutz, B.H. B-alkyl sp3-sp2 Suzuki-Miyaura couplings under mild aqueous micellar conditions. Org. Lett. 2018, 20, 2902-2905. [CrossRef] [PubMed]

326. Handa, S.; Smith, J.D.; Zhang, Y.; Takale, B.S.; Gallou, F.; Lipshutz, B.H. Sustainable HandaPhos-ppm Palladium technology for copper-free Sonogashira couplings in water under mild conditions. Org. Lett. 2018, 20, 542-545. [CrossRef] [PubMed]

327. Isley, N.A.; Wang, Y.; Gallou, F.; Handa, S.; Aue, D.H.; Lipshutz, B.H. A micellar catalysis strategy for Suzuki-Miyaura crosscouplings of 2-pyridyl MIDA boronates: No copper, in water, very mild conditions. ACS Catal. 2017, 7, 8331-8337. [CrossRef]

328. Brals, J.; Smith, J.D.; Ibrahim, F.; Gallou, F.; Handa, S. Micelle-enabled palladium catalysis for convenient sp2-sp3 coupling of nitroalkanes with aryl bromides in water under mild conditions. ACS Catal. 2017, 7, 7245-7250. [CrossRef]

329. Cen, J.; Wu, Y.; Li, J.; Huang, L.; Wu, W.; Zhu, Z.; Yang, S.; Jiang, H. Switchable reactivity between vinyl azides and terminal alkyne by nano copper catalysis. Org. Lett. 2019, 21, 2090-2094. [CrossRef]

330. Nandi, D.; Perla, V.K.; Ghosh, S.K.; Arderne, C.; Mallick, K. Copper-azide nanoparticle: A 'catalyst-cum-reagent' for the designing of 5-alkynyl 1,4-disubstituted triazoles. Sci. Rep. 2020, 10, 16720. [CrossRef]

331. Wang, X.; Wu, C.; Sun, Y.; Yao, X. Copper nanoparticles catalyzed economical synthesis of 3-substituted isocoumarins from 2-chlorobenzoic acids/amides and 1,3-diketones. Tetrahedron Lett. 2017, 58, 3164-3167. [CrossRef]

332. Shadmehr, A.; Abdolmohammadi, S. An expedient synthesis of [1]benzopyrano[b]pyridine-3-carbonitriles catalyzed by $\mathrm{NiCr}_{2} \mathrm{O}_{4}$ NPs. Polycycl. Aromat. Comp. 2020, 1739083. Available online: https://www.tandfonline.com/doi/full/10.1080/10406638.2020.17 39083 (accessed on 10 August 2021).

333. Mart, M.; Trzeciak, A.M. The synthesis of $\beta$-enaminones using trialkylamines and a Pd/DNA catalyst. Mol. Catal. 2021, 502, 111365. [CrossRef]

334. Mart, M.; Trzeciak, A.M. Solvent switchable Pd/DNA catalyst in carbonylative Sonogashira coupling. Mol. Catal. 2020, 494, 111124. [CrossRef]

335. Mart, M.; Tylus, W.; Trzeciak, A.M. Pd/DNA as a highly active and recyclable catalyst for aminocarbonylation and hydroxycarbonylation in water: The effect of $\mathrm{Mo}(\mathrm{CO})_{6}$ on the reaction course. Mol. Catal. 2019, 462, 28-36. [CrossRef]

336. Mart, M.; Tylus, W.; Trzeciak, A.M. Pd/DNA as highly active and recyclable catalyst of Suzuki-Miyaura coupling. Catalysts 2018, 8, 552. [CrossRef]

337. Alsalahi, W.; Trzeciak, A.M. Rh/DNA nanoparticles, synthesis, characterization and catalytic activity in "on water" asymmetric hydroformylation reaction. ChemistrySelect 2018, 3, 1727-1736. [CrossRef]

338. Kataria, M.; Deol, H.; Singh, G.; Kumar, M.; Bhalla, V. Visible-light-mediated dehydrogenative cross-coupling between terminal alkynes and aldehydes by employing supramolecular polymeric ensemble of PBI derivative. New J. Chem. 2018, 42, 822-826. [CrossRef]

339. Kataria, M.; Kumar, M.; Singh, Z.; Bhalla, V. Gold nanoparticles immobilized polymeric PBI derivative: Productive, portable, and photocatalytic system for Heck coupling. ACS Sustain. Chem. Eng. 2018, 6, 8223-8229. [CrossRef]

340. Jeffery, T. Heck-type reactions in water. Tetrahedron Lett. 1994, 35, 3051-3054. [CrossRef]

341. Nagata, T.; Obora, Y. N,N-Dimethylformamide-protected single-sized metal nanoparticles and their use as catalysts for organic transformations. ACS Omega 2020, 5, 98-103. [CrossRef]

342. Prechtl, M.H.G.; Scholten, J.D.; Dupont, J. Carbon-carbon cross coupling reactions in ionic liquids catalyzed by palladium metal nanoparticles. Molecules 2010, 15, 3441-3461. [CrossRef] [PubMed]

343. Gálvez-Martínez, E.; Aguilar-Granda, A.; Rodríguez-Molina, B.; Haropérez, G.; Kozina, A. Catalytic evaluation of citratestabilized palladium nanoparticles in the Sonogashira reaction for the synthesis of 1,4-bis[(trimethylsilyl)ethynyl] benzene. Catal. Commun. 2021, 153, 106269. [CrossRef]

344. Ishida, J.; Nakatsuji, M.; Nagata, T.; Kawasaki, H.; Suzuki, T.; Obora, Y. Synthesis and characterization of N,N-dimethylformamideprotected palladium nanoparticles and their use in the Suzuki-Miyaura cross-coupling reaction. ACS Omega 2020, 5, 9598-9604. [CrossRef] [PubMed]

345. Olekszyszen, D.N.; Albuquerque, B.L.; de Silva, O.D.; Tripodi, G.L.; de Oliveira, D.C.; Domingos, J.B. Core-shell PdCu bimetallic colloidal nanoparticles in Sonogashira cross-coupling reaction: Mechanistic insights into the catalyst mode of action. Nanocale 2020, 12, 1171-1179. [CrossRef]

346. Fernández, E.; Rivero-Crespo, M.A.; Domínguez, I.; Rubio-Marués, P.; Oliver-Meseguer, J.; Liu, L.; Cabrero-Antonino, M.; Gavara, R.; Hernández-Garido, J.C.; Boronat, M.; et al. Base-controlled Heck, Suzuki, and Sonogashira reactions catalyzed by ligand-free platinum or palladium single atom and subnanometer clusters. J. Am. Chem. Soc. 2019, 141, 1928-1940. [CrossRef]

347. Sarhid, I.; Abdellah, I.; Martini, C.; Huc, V.; Dragoe, D.; Beaunier, P.; Lampre, I.; Remita, H. Plasmonic catalysis for the Suzuki-Miyaura cross-coupling reaction using palladium nanoflowers. New J. Chem. 2019, 43, 4349-4355. [CrossRef]

348. Wirwis, A.; Trzeciak, A.M. Ligand-free palladium-catalyzed tandem pathways for the synthesis of 4,4-diarylbutanones and 4,4-diaryl-3-butenones under microwave conditions. Appl. Organomet. Chem. 2019, 33, e4870. Available online: https:// onlinelibrary.wiley.com/doi/abs/10.1002/aoc.4870 (accessed on 10 August 2021). [CrossRef]

349. Molteni, G.; Ferretti, A.M.; Mondini, S.; Ponti, A. Nitrilimine cycloadditions catalyzed by iron oxide nanoparticles. J. Nanopart. Res. 2018, 20, 79. [CrossRef] 
350. Sable, V.; Maindan, K.; Bhilare, S.; Chrysochos, N.; Schulzke, C.; Kapdi, A.R. An active palladium colloidal catalyst for the selective oxidative heterocoupling of (hetero)aryl boronic acids. Chem. Asian J. 2018, 13, 2489-2498. [CrossRef]

351. Jeanne-Julien, L.; Astier, E.; Lai-Kuen, R.; Genta-Jouve, G.; Roulland, E. Palladium nanoparticle-catalyzed stereoretentive cross-coupling of alkenyl sulfides with Grignard reagents. Org. Lett. 2018, 20, 1430-1434. [CrossRef]

352. Vargas, D.R.; Cook, S.P. Palladium nanoparticles: Chemoselective control for reductive Heck with aryl triflates and 2,3dihydrofuran. Tetrahedron 2018, 74, 3314-3317. [CrossRef]

353. Wirwis, A.; Feder-Kubis, J.; Trzeciak, A.M. Two efficient pathways for the synthesis of aryl ketones catalyzed by phosphorus-free palladium catalysts. Mol. Catal. 2018, 445, 61-72. [CrossRef]

354. Onishi, K.; Oikawa, K.; Yano, H.; Suzuki, T.; Obora, Y. N,N-Dimethylformamide-stabilized palladium nanoclusters as a catalyst for Larock indole synthesis. RSC Adv. 2018, 8, 11324-11329. [CrossRef]

355. Reina, A.; Serrano-Maldonado, A.; Teuma, E.; Martin, E.; Gómez, M. Palladium nanocatalysts in glycerol: Tuning the reactivity by effect of the stabilizer. Catal. Commun. 2018, 104, 22-27. [CrossRef]

356. Arvelos, M.S.; Silva, A.C.; de Souza, A.L.F.; Achete, C.A.; Vasconcelos, T.L.; Robertis, E.; Archanjo, B.S.; Aguiar, L.C.S.; Malta, L.F.B.; Senra, J.D. Revealing Pd nanoparticles formation from PEG-mediated decomposition of organometallic precursor and their application as catalyst for the synthesis of n-extended carbazoles. ChemistrySelect 2018, 3, 9725-9730. [CrossRef]

357. Feiz, A.; Loni, M.; Naderi, S.; Bazgir, A. The $\beta$-cyclodextrin decorated with palladium nanoparticles without pretreatment: An efficient heterogenous catalyst for biaryls synthesis. Appl. Organomet. Chem. 2018, 32, e4608. [CrossRef]

358. Scattolin, T.; Canovese, L.; Visentin, F.; Paganelli, S.; Canton, P.; Demitri, N. Synthesis of novel allyl palladium complexes bearing purine based NHC and a water soluble phosphine and their catalytic activity in the Suzuki-Miyaura coupling in water. Appl. Organomet. Chem. 2018, 32, e4034. [CrossRef]

359. Oka, H.; Kitai, K.; Suzuki, T.; Obora, Y. N,N-Dimethylformamide-stabilized copper nanoparticles as a catalyst precursor for Sonogashira-Hagihara cross coupling. RSC Adv. 2017, 7, 22869-22874. [CrossRef]

360. Zong, Y.; Wang, J.; An, P.; Yue, G.; Pan, Y.; Wang, X. Self-assembled Pd nanoparticle-containing ionic liquid: Efficient and reusable catalyst for the Heck reaction in water. Appl. Organomet. Chem. 2017, 31, e3762. [CrossRef]

361. Asada, S.; Nito, A.; Miyagi, Y.; Ishida, J.; Obora, Y.; Sanda, F. Sonogashira-Hagihara and Mizoroki-Heck coupling polymerizations catalyzed by Pd nanoclusters. Macromolecules 2017, 50, 4083-4087. [CrossRef]

362. Ge, J.; Jiang, J.; Yuan, C.; Zhang, C.; Liu, M. Palladium nanoparticles stabilized by phosphine ligand for aqueous phase room temperature Suzuki-Miyaura coupling. Tetrahedron Lett. 2017, 58, 1142-1145. [CrossRef]

363. Sarmah, M.; Mondal, M.; Gohain, S.B.; Bora, U. Gallic acid-derived palladium(0) nanoparticles as in situ-formed catalyst for Sonogashira cross-coupling reaction in ethanol under open air. Catal. Commun. 2017, 90, 31-34. [CrossRef]

364. Mondal, M.; Begum, T.; Gogoi, P.K.; Bora, U. Gallic acid derived palladium(0) nanoparticles: An in situ formed "green and recyclable" catalyst for Suzuki-Miyaura coupling in water. ChemistrySelect 2016, 1, 4645-4651. [CrossRef]

365. Arora, A.; Oswal, P.; Rao, G.K.; Kumar, S.; Singh, A.K.; Kumar, A. Catalytically active nanosized Pd, Te $_{4}$ (telluropalladinite) and PdTe (kotulskite) alloys: First precursor-architecture controlled synthesis using palladium complexes of organotellurium compounds as single source precursors. RSC Adv. 2021, 11, 7214-7224. [CrossRef]

366. Oswal, P.; Arora, A.; Kaushal, J.; Rao, G.K.; Kumar, S.; Singh, A.K.; Kumar, A. Ultra-small palladium nano-particles synthesized using bulky S/Se and N donor ligands as a stabilizer: Application as catalysts for Suzuki-Miyaura coupling. RSC Adv. 2019, 9, 22313-22319. [CrossRef]

367. Sharma, P.; Arora, A.; Oswal, P.; Rao, G.K.; Kaushal, J.; Kumar, S.; Kumar, S.; Singh, M.P.; Singh, A.K.; Kumar, A. Bidentate organochalcogen ligands (N, E.; E = S/Se) as stabilizers for recyclable palladium nanoparticles and their application in SuzukiMiyaura coupling reactions. Polyhedron 2019, 171, 120-127. [CrossRef]

368. Dachwitz, S.; Duwe, D.H.; Wang, Y.H.; Gruß, H.; Hannappel, Y.; Hellweg, T.; Sewald, N. Suzuki-Miyaura cross-coupling of bromotryptophan derivatives at ambient temperature. Chem. Eur. J. 2020, 26, 16357-16364. [CrossRef]

369. Song, J.; Feng, X.; Yamamoto, Y.; Almansour, A.I.; Arumugam, N.; Kumar, R.S.; Bao, M. Carboxylative coupling of chloromethyl(hetero)arenes with allytrimethoxysilane catalyzed by palladium nanoparticles. Asian J. Org. Chem. 2017, 6, 177-183. [CrossRef]

370. Feng, X.; Sun, A.; Zhang, S.; Yu, X.; Bao, M. Palladium-catalyzed carboxylative coupling of benzyl chlorides with allyltributylstannane: Remarkable effect of palladium nanoparticles. Org. Lett. 2013, 15, 108-111. [CrossRef]

371. Raheem, A.A.; Thangasamy, P.; Sathish, M.; Praveen, C. Supercritical water assisted preparation of recyclable gold nanoparticles and their catalytic utility in cross-coupling reactions under sustainable conditions. Nanoscale Adv. 2019, 1, 3177-3191. [CrossRef]

372. Kiani, M.; Bagherzadeh, M.; Meghdadi, S.; Fadaei-Tirani, F.; Babaie, M.; Schenk-Joß, K. Promising new catalytic properties of a $\mathrm{Co}(\mathrm{II})$-carboxamide complex and its derived $\mathrm{Co}_{3} \mathrm{O}_{4}$ nanoparticles for the Mizoroki-Heck and the epoxidation reactions. Appl. Organomet. Chem. 2020, 34, e5911. [CrossRef]

373. Tanaka, K.; Fujiki, K. Bis[N,N'-(2-indalolyl)]-1,5-diazacyclooctane as unique metal ligand: Self-assemble of palladium nanoparticles and catalytic reactivity on C-C bond formation. Synthesis 2018, 50, 1097-1104. [CrossRef]

374. Xia, Y.-T.; Wu, J.-J.; Zhang, C.-Y.; Mao, M.; Ji, Y.-G.; Wu, L. Cascade alkynylation and highly selective hydrogenation catalyzed by binaphthyl-palladium nanoparticles accessing phosphinyl (Z)-[3]dendralenes. Org. Lett. 2019, 21, 6383-6387. [CrossRef] [PubMed] 
375. Parveen, N.; Sekar, G. Palladium nanoparticle-catalyzed stereoselective domino synthesis of all-carbon tetrasubstituted olefin containing oxindoles via carbopalladation/C-H activation. J. Org. Chem. 2020, 85, 10514-10524. [CrossRef] [PubMed]

376. Parveen, N.; Sekar, G. Palladium nanoparticle-catalyzed stereoselective domino synthesis of 3-allylidene-2(3H)-oxindoles and 3-allylidene-2(3H)-benzofuranones. J. Org. Chem. 2020, 85, 4682-4694. [CrossRef] [PubMed]

377. Parveen, N.; Sekar, G. Palladium nanoparticles-catalyzed synthesis of indanone derivatives via intramolecular reductive Heck reaction. Adv. Synth. Catal. 2019, 361, 4581-4595. [CrossRef]

378. Parveen, N.; Saha, R.; Sekar, G. Stable and reusable palladium nanoparticles-catalyzed conjugate addition of aryl iodides to enones: Route to reductive Heck products. Adv. Synth. Catal. 2017, 359, 3741-3751. [CrossRef]

379. Kobayashi, M.; Yamaguchi, H.; Suzuki, T.; Obora, Y. Cross $\beta$-alkylation of primary alcohols catalyzed by DMF-stabilized iridium nanoparticles. Org. Biomol. Chem. 2021, 19, 1950-1954. [CrossRef]

380. Oikawa, K.; Itoh, S.; Yano, H.; Kawasaki, H.; Obora, Y. Preparation and use of DMF-stabilized iridium nanoclusters as methylation catalysts using methanol as the C1 source. Chem. Commun. 2017, 53, 1080-1083. [CrossRef]

381. Wang, J.; Feng, X.; Song, J.; Gao, Z.; Wang, W.-H.; Bao, M. The ultrasmall palladium nanoparticles catalyzed telomerization of $\mathrm{CO}_{2}$ with 1,3-butadiene at room temperature: Selective synthesis of $\delta$-lactone. ChemistrySelect 2020, 5, 9404-9408. [CrossRef]

382. Selvaraj, K.; Daoud, A.; Alarifi, S.; Idhayadhulla, A. Tel-Cu-NPs catalyst: Synthesis of naphtho[2,3-g]phthalazine derivatives as potential inhibiters of tyrosinase enzymes and their investigation in kinetic, molecular docking, and cytotoxicity studies. Catalysts 2020, 10, 1442. [CrossRef]

383. Mišurović, J.; Mojović, M.; Marjanović, B.; Vulić, P.; Ćirić-Marjanović, G. Magnetite nanoparticles-catalyzed synthesis of conductive poly(p-aminodiphenylamine). Synth. Met. 2020, 269, 116577. [CrossRef]

384. Mišurović, J.; Mojović, M.; Marjanović, B.; Vulić, P.; Ćirić-Marjanović, G. Magnetite nanoparticles-catalyzed synthesis of conductive polyaniline. Synth. Met. 2019, 257, 116174. [CrossRef]

385. Yuan, M.; Xu, L.; Cui, X.; Lv, J.; Zhang, P.; Tang, H. Facile synthesis of ultrahigh molecular weight poly(methyl methacrylate) by organic halides in the presence of palladium nanoparticles. Polymers 2020, 12, 2747. [CrossRef]

386. Rosa-Pardo, I.; Casadevall, C.; Schmidt, L.; Claros, M.; Galian, R.E.; Lloret-Fillol, J.; Pérez-Prieto, J. The synergy between the $\mathrm{CsPbB}_{3}$ nanoparticle surface and the organic ligand becomes manifest in a demanding carbon-carbon coupling reaction. Chem. Commun. 2020, 56, 5026-5029. [CrossRef] 